Pesq. Vet. Bras. 38(1):195-221, janeiro 2018

\title{
Osteologia do membro torácico de Lycalopex gymnocercus Fischer, 1814 (Carnivora, Mammalia): abordagens comparada, radiográfica e osteométrica ${ }^{1}$
}

\author{
Paulo de Souza Junior ${ }^{2,5 *}$, Lucas M.P.R. Santos ${ }^{2}$, Erick C. Souza ${ }^{2}$, Wilson V. Souza ${ }^{2}$, \\ Natan C. Carvalho ${ }^{2}$, Bruno L. Anjos ${ }^{3}$, Cristiano C. Ferreira ${ }^{4}$ e André L.Q. Santos ${ }^{5}$
}

\begin{abstract}
Souza Junior P., Santos L.M.P.R., Souza E.C., Souza W.V., Carvalho N.C., Anjos B.L., Ferreira C.C. \& Santos A.L.Q. 2018. [Osteology of the thoracic limb in the Lycalopex gymnocercus Fischer, 1814 (Carnivora, Mammalia): comparative, radiogrpahic and osteometric approaches.] Osteologia do membro torácico de Lycalopex gymnocercus Fischer, 1814 (Carnivora, Mammalia): abordagens comparada, radiográfica e osteométrica. Pesquisa Veterinária Brasileira 38(1):195-221. Laboratório de Anatomia Animal, Universidade Federal do Pampa, campus Uruguaiana, Rodovia BR-472 Km 592, Cx. Postal 118, Uruguaiana, RS 97508-000, Brazil. E-mail: paulosouza@unipampa.edu.br

The forelimb is the part of the post-cranial skeleton that provides more information about locomotion and life habits of a species. The objective of this study was to perform a detailed macroscopic, comparative, radiographic and osteometric investigation of the thoracic limb of Lycalopex gymnocercus. Twenty-four adult specimens collected dead from roadkill were studied. Analysis included macroscopic and comparative descriptions to other canids, radiographic images for recognition of trabeculation patterns and topographical arrangement of bones, linear and three-dimensional measurements, and histological evaluation of the clavicles. The forelimb skeleton of L. gymnocercus presented morphological and functional adaptations in every segment for a specialized cursorial locomotion and some ability to pronation and supination for capture of small vertebrates. There was a tendency for the bones to be longer in males, especially in the distal end of humerus, presumably to fixation of stronger antebrachial muscles. The vestigial clavicle bone was found in all the specimens, had a predominantly cartilaginous nature and was significantly larger in males. The basic conformation of the forelimb skeleton was similar to that of domestic and wild canids described in the literature, although peculiar characteristics of L. gymnocercus have been found.
\end{abstract}

INDEX TERMS: Lycalopex gymnocercus, locomotion, osteology, osteometry, Pampa's Fox, radiography, wild carnivorans.

RESUMO.- 0 membro torácico é a parte do esqueleto pós-craniano que mais informações oferece sobre a locomoção e hábitos de vida de uma espécie. Objetivou-se realizar uma

\footnotetext{
${ }^{1}$ Recebido em 8 de fevereiro de 2017.

Aceito para publicação em 21 de julho de 2017.

${ }^{2}$ Laboratório de Anatomia Animal, Universidade Federal do Pampa (Unipampa), campus Uruguaiana, Rodovia BR-472 Km 592, Caixa Postal 118, Uruguaiana, RS 97508-000, Brasil. *Autor para correspondência: paulosouza@unipampa.edu.br

${ }^{3}$ Laboratório de Patologia Veterinária, Unipampa, Rodovia BR-472 Km 592, Cx. Postal 118, Uruguaiana, RS 97508-000, Brasil.

${ }^{4}$ Núcleo do Desenho Técnico, Unipampa, Av. Maria Anunciação Gomes Godoy 1650, Bagé, RS 96413-172, Brasil.

${ }^{5}$ Laboratório de Ensino e Pesquisa em Animais Silvestres (LAPAS), Faculdade de Medicina Veterinária, Universidade Federal de Uberlândia (UFU), Rua Piauí, Bloco 4S, Jardim Umuarama, Uberlândia, MG 38400-902, Brasil.
}

descrição macroscópica, comparativa, radiográfica e osteométrica do esqueleto do membro torácico de Lycalopex gymnocercus. Para tal foram analisados ossos de 24 espécimes adultos coletados mortos em rodovias. Foram realizadas descrições macroscópicas e comparadas com as de outros canídeos, imagens radiográficas para reconhecimento dos padrões de trabeculação e topografia óssea, mensurações lineares e tridimensionais e avaliações histológicas das clavículas. $O$ esqueleto do membro torácico de $L$. gymnocercus apresentou adaptações morfofuncionais em todos os segmentos para a locomoção cursorial especializada e alguma capacidade de pronação e supinação para captura de presas de porte menor. Houve uma tendência de os ossos serem maiores nos machos, especialmente na região distal do úmero, presumivelmente para a fixação de 
músculos antebraquiais mais fortes. A clavícula vestigial foi encontrada em todos os espécimes, teve natureza predominantemente cartilagínea e foi significativamente maior nos machos. A conformação básica do esqueleto do membro torácico foi semelhante à dos canídeos domésticos e silvestres descritos na literatura, ainda que particularidades de L. gymnocercus sejam encontradas.

TERMOS DE INDEXAÇÃO: Osteologia, Lycalopex gymnocercus, radiografia, osteometria, carnívoros silvestres, locomoção cursorial, raposa-dos-pampas.

\section{INTRODUÇÃO}

Lycalopex gymnocercus Fisher, 1814 é um canídeo de médio porte, conhecido vulgarmente como graxaim-do-campo, raposa-dos-pampas, zorro-de-Azara, zorro-pampiano entre outras designações (Jiménez et al. 2008). Ocorre no leste da Bolívia, oeste e centro do Paraguai, Uruguai, norte e centro da Argentina e sul do Brasil (Queirolo et al. 2013). Alcança apenas poucos anos em vida livre, ainda que possa atingir até 14 anos em cativeiro. De hábitos onívoros, alimenta-se de lebres, pequenos roedores, aves, frutas nativas e exóticas, insetos, carniça ou ainda de presas de maior porte como tatus, gambás, lagartos e peixes. Têm preferência por áreas abertas e planas com clima subúmido a seco (Lucherini \& Luengos Vidal 2008). Digitígrados, nas áreas de sobreposição de dieta com Cerdocyon thous no Brasil, são os mais carnívoros (Vieira \& Port 2007).

As adaptações morfofuncionais no esqueleto pós-craniano são indicadores confiáveis sobre a locomoção e exploração do habitat pelas espécies e permitem, inclusive, inferir conclusões sobre grupos extintos (Salesa et al. 2010, Meloro et al. 2013, Samuels et al. 2013). Entretanto, estudos sobre esqueletos pós-cranianos de canídeos sul-americanos são escassos desde as análises de Hildebrand (1954). Além disso, pouco se conhece sobre a anatomia de espécies silvestres para procedimentos de diagnóstico e tratamento em zoológicos (Stoskopf 1989).

Entre os elementos pós-cranianos, os ossos dos membros torácicos são funcionalmente mais informativos quando comparados aos dos membros pélvicos. Isto explica-se pois suportam a maior parte da massa corporal do animal, além de serem melhores indicadores da ecologia da locomoção e de outros comportamentos como forrageamento, acasalamento e captura da presa (Ewer 1973, Fabre et al. 2014, Martín-Serra et al. 2014, Fabre et al. 2015). Por exemplo, membros torácicos alongados, com metacarpianos compridos, côndilos umerais reduzidos, úmero alongado e ossatura leve são características expressas em carnívoros cursoriais especializados (Samuels et al. 2013). Em contrapartida, nos canídeos semi-fossoriais, como Speothos venaticus, são esperados membros relativamente robustos, úmero curto, epicôndilos umerais desenvolvidos, olecranos alongados e falanges distais compridas (Samuels et al. 2013).

Os métodos utilizados para detalhar características morfofuncionais dos ossos de carnívoros incluem desde a descrição macroscópica comum (Evans \& DeDeLahunta 2013) e comparativa (Hildebrand 1954, Feeney 1999), exploração de anatomia radiográfica (Schebitz \& Wilkens 1987, Meachen-Samuels 2010, Van Staden 2014), medidas lineares de distâncias entre pontos de referências (Vonden-Driesch 1976) acrescidas de índices comparativos (Samuels et al. 2013, Janis \& Figueirido 2014) até modelos de morfometria geométrica bi ou tridimensional (Andersson 2004, Meloro et al. 2013, Martín-Serra et al. 2014).

Diante da escassez de conhecimentos sobre esqueleto pós-craniano de canídeos sul-americanos e da relevância funcional dos membros torácicos, realizou-se um detalhamento da osteologia do membro torácico de L. gymnocercus. A partir das adaptações reconhecidas no esqueleto, objetivou-se apontar características anatômicas comparadas e inferir hábitos em vida livre.

\section{MATERIAL E MÉTODOS}

Amostra. Para este estudo foram disponibilizados 24 espécimes de Lycalopex gymnocercus, quinze machos e nove fêmeas (Quadro 1), adultos, coletados mortos em rodovias da mesorregião sudoeste do Rio Grande do Sul, Brasil (autorização IBAMA/ SISBIO no 33667). Apenas espécimes em condições ideais para cada análise foram selecionados; portanto, nem todos os espécimes foram aproveitados em todas as etapas em virtude das condições de integridade dos elementos a serem analisados.

Descrição macroscópica. Para descrição macroscópica e osteometria com paquímetro os ossos de 16 espécimes foram inicialmente preparados com raspagem dos tecidos moles, cuidando-se para preservar os ossos sesamoides, submetidos à fervura por cerca de 30 minutos, seguida de nova raspagem e finalmente clareamento em peróxido de hidrogênio a 130 vol. por 30 minutos. Cada osso foi examinado para identificação dos acidentes anatô-

Quadro 1. Número de registro na coleção, tipo de análise, sexo e cidade de coleta dos espécimes de Lycalopex gymnocercus estudados. Finalidades: histologia das clavículas (HC), radiografia dos membros (RM), radiografia dos ossos isolados (RO), osteometria com paquímetro (OP), osteometria dos sesamoides (OS), osteometria tridimensional (3D); Sexos: masculino (M) e feminino (F)

\begin{tabular}{|c|c|c|c|}
\hline Registro & Tipo de análise & Sexo & Local de coleta \\
\hline 5134 & HC e RM & $\mathrm{F}$ & Uruguaiana \\
\hline 5141 & RM, HC & M & São Vicente do Sul \\
\hline 5261 & $\mathrm{RO}, \mathrm{HC}$ & M & S. Francisco de Assis \\
\hline 5269 & $\mathrm{HC}$ & M & São Gabriel \\
\hline 5274 & OP, OS, RO, HC & M & Uruguaiana \\
\hline 5597 & OP, OS, HC & $\mathrm{F}$ & Uruguaiana \\
\hline 5598 & $\mathrm{HC}$ & $\mathrm{F}$ & São Francisco de Assis \\
\hline 5603 & OP, OS, HC & M & Barra do Quaraí \\
\hline 8414 & $\mathrm{OP}$ & M & Uruguaiana \\
\hline 8433 & $\mathrm{OP}$ & $\mathrm{F}$ & Dilermando de Aguiar \\
\hline 8501 & $\mathrm{HC}$ & M & Alegrete \\
\hline 8519 & OP, OS, HC & $\mathrm{F}$ & Uruguaiana \\
\hline 8533 & $\mathrm{HC}$ & M & São Gabriel \\
\hline 8576 & 3D, OP, OS, RO & $\mathrm{F}$ & Uruguaiana \\
\hline 8582 & $\mathrm{OP}$ & $\mathrm{F}$ & Uruguaiana \\
\hline 8583 & $\mathrm{OP}$ & M & Itaqui \\
\hline 8584 & OP & M & São Gabriel \\
\hline 8585 & $\mathrm{OP}$ & $\mathrm{F}$ & Alegrete \\
\hline 8586 & OP & $\mathrm{F}$ & Uruguaiana \\
\hline 8587 & $\mathrm{OP}$ & M & Uruguaiana \\
\hline 8588 & $\mathrm{OP}$ & M & Santiago \\
\hline 8589 & $\mathrm{OP}$ & M & Uruguaiana \\
\hline 8590 & OP & M & Vila Nova do Sul \\
\hline 8591 & OP, OS & M & Uruguaiana \\
\hline
\end{tabular}


Quadro 2. Lista de abreviaturas e medidas lineares realizadas com paquímetro nos ossos de Lycalopex gymnocercus

\begin{tabular}{|c|c|}
\hline Abreviação & Medida \\
\hline \multicolumn{2}{|l|}{ Escápula } \\
\hline $\mathrm{HS}^{1}$ & Altura da escápula ao longo da espinha. \\
\hline DHA $^{1}$ & $\begin{array}{l}\text { Altura diagonal, medida desde o ponto mais } \\
\text { ventral até o ângulo caudal. }\end{array}$ \\
\hline $\mathrm{SLC}^{1}$ & Menor comprimento do colo da escápula. \\
\hline $\mathrm{GLP}^{1}$ & $\begin{array}{l}\text { Comprimento da região ventral, incluindo } \\
\text { o tubérculo supraglenoide. }\end{array}$ \\
\hline $\mathrm{LG}^{1}$ & Comprimento da cavidade glenoide. \\
\hline $\mathrm{BG}^{1}$ & Largura da cavidade glenoide. \\
\hline \multicolumn{2}{|l|}{ Úmero } \\
\hline $\mathrm{GL}^{1,2}$ & Comprimento total desde o tubérculo maior \\
\hline $\mathrm{GLC}^{1}$ & Comprimento total desde a cabeça do úmero \\
\hline $\mathrm{Dp}^{1}$ & Comprimento crânio-caudal da epífise proximal \\
\hline $\mathrm{SD}^{1,2}$ & Menor largura no meio da diáfise \\
\hline $\mathrm{Bd}^{1,2}$ & Largura da extremidade distal (entre epicôndilos) \\
\hline $\mathrm{DPCL}^{2}$ & $\begin{array}{l}\text { Comprimento da crista do tubérculo maior } \\
\text { (delto-peitoral) }\end{array}$ \\
\hline \multicolumn{2}{|r|}{ 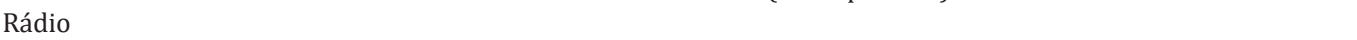 } \\
\hline $\mathrm{GL}^{1,2}$ & Comprimento total do rádio \\
\hline $\mathrm{Bp}^{1}$ & Largura na epífise proximal \\
\hline $\mathrm{SD}^{1}$ & Menor largura da diáfise \\
\hline $\mathrm{Bd}^{1}$ & Largura na epífise distal \\
\hline \multicolumn{2}{|l|}{ Ulna } \\
\hline $\mathrm{GL}^{1}$ & Comprimento total da ulna \\
\hline $\mathrm{DPA}^{1}$ & Profundidade desde o processo ancôneo \\
\hline $\mathrm{SDO}^{1}$ & Menor profundidade do olecrano \\
\hline $\mathrm{BPC}^{1}$ & Largura entre os processos coronoides \\
\hline $\mathrm{FUL}^{2}$ & $\begin{array}{l}\text { Comprimento funcional da ulna (desde o } \\
\text { processo ancôneo até o processo estiloide) }\end{array}$ \\
\hline $\mathrm{ULOL}^{2}$ & Comprimento do olecrano \\
\hline $\mathrm{UD}^{2}$ & Diâmetro mediolateral no meio da diáfise \\
\hline \multicolumn{2}{|l|}{ Carpianos Intermédio-radial, Ulnar e Acessório } \\
\hline $\mathrm{CIRGB}^{1}, \mathrm{CUGB}^{1}$ e $\mathrm{CAGB}^{1}$ & Largura látero-medial \\
\hline CIRGH, CUGH e CAGH & Altura próximo-distal \\
\hline CIRGP, CUGP e CAGP & Profundidade dorso-palmar \\
\hline \multicolumn{2}{|l|}{ Carpianos I, II, III e IV } \\
\hline $\mathrm{CIGB}^{1}, \mathrm{CIIGB}^{1}, \mathrm{CIIIGB}^{1}$ e $\mathrm{CIVGB}^{1}$ & Largura látero-medial \\
\hline CIGH, CIIGH, CIIIGH e CIVGH & Altura próximo-distal \\
\hline CIGP, CIIGP, CIIIGP e CIVGP & Profundidade dorso-palmar \\
\hline \multicolumn{2}{|l|}{ Metacarpianos I, II, III, IV e V } \\
\hline MCIGL $^{1}$, MCIIGL $^{1}$, MCIIIGL $^{1,2}$, MCIVGL $^{1}$ e MCVGL ${ }^{1}$ & Comprimento total \\
\hline MCIBd $^{1}, \mathrm{MCIIBd}^{1}, \mathrm{MCIIIBd}^{1}, \mathrm{MCIVBd}^{1}$ e MCVBd $^{1}$ & Largura distal \\
\hline \multicolumn{2}{|l|}{ Falange Proximal (Dígitos I, II, III, IV e V) } \\
\hline FPIGL $^{1}$, FPIIGL ${ }^{1}$, FPIIIGL ${ }^{1,2}$, FPIVGL ${ }^{1}$ e FPVGL ${ }^{1}$ & Comprimento total \\
\hline FPIBp $^{1}$, FPIIBp $^{1}$, FPIIIBp $^{1}$, FPIVBp $^{1}$ e FPVBp ${ }^{1}$ & Largura na epífise proximal \\
\hline 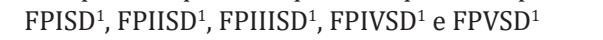 & Menor diâmetro da diáfise \\
\hline FPIBd $^{1}$, FPIIBd $^{1}$, FPIIIBd $^{1}$, FPIVBd $^{1}$ e FPVBd ${ }^{1}$ & Largura na epífise distal \\
\hline \multicolumn{2}{|l|}{ Falange Média (Dígitos II, III, IV e V) } \\
\hline FMIGL $^{1}$, FMIIGL ${ }^{1}$, FMIIIGL $^{1}$, FMIVGL ${ }^{1}$ e FMVGL ${ }^{1}$ & Comprimento total \\
\hline FMIBp $^{1}$, FMIIBp $^{1}$, FMIIIBp $^{1}$, FMIVBp $^{1}$ e FMVBp ${ }^{1}$ & Largura na epífise proximal \\
\hline FMISD $^{1}$, FMIISD ${ }^{1}$, FMIIISD $^{1}$, FMIVSD ${ }^{1}$ e FMVSD ${ }^{1}$ & Menor diâmetro da diáfise \\
\hline FMIBd $^{1}$, FMIIBd $^{1}$, FMIIIBd $^{1}$, FMIVBd ${ }^{1}$ e FMVBd ${ }^{1}$ & Largura na epífise distal \\
\hline \multicolumn{2}{|l|}{ Falange Distal (Dígitos I, II, III, IV e V) } \\
\hline FDIGL $^{1}$, FDIIGL $^{1}$, FDIIIGL $^{1,2}$, FDIVGL $^{1}$ e FDVGL ${ }^{1}$ & Comprimento total \\
\hline FDIHP $^{1}$, FDIIHP $^{1}$, FDIIIHP $^{1}$, FDIVHP $^{1}$ e FDVHP ${ }^{1}$ & Altura desde o processo extensor \\
\hline FDILd $^{1}$, FDIILd $^{1}$, FDIIILd $^{1}$, FDIVLd $^{1}$ e FDVLd ${ }^{1}$ & Comprimento da face dorsal \\
\hline FDIGB $^{1}$, FDIIGB $^{1}$, FDIIIGB $^{1}$, FDIVGB $^{1}$ e FDVGB ${ }^{1}$ & Maior largura \\
\hline \multicolumn{2}{|c|}{ Sesamoides proximais, axiais ou abaxiais dos dedos II, III, IV e V. } \\
\hline SPAxLII, SPAxLIII, SPAxLIV, SPAxLV & Maior comprimento do sesamoide axial \\
\hline SPAbLII, SPAbLIII, SPAbLIV, SPAbLV & Maior comprimento do sesamoide abaxial \\
\hline SPAxBII, SPAxBIII, SPAxBIV, SPAxBV & Maior largura do sesamoide axial \\
\hline SPAbBII, SPAbBIII, SPAbBIV, SPAbBV & Maior largura do sesamoide abaxial \\
\hline
\end{tabular}


micos (projeções e depressões), seguida de descrição comparativa com os ossos de dois espécimes de Cerdocyon thous (um macho e uma fêmea) e dois de Canis lupus familiaris (um macho e uma fêmea) disponíveis no acervo do Laboratório de Anatomia Animal da Universidade Federal do Pampa (Unipampa). As observações também foram confrontadas com as descrições e ilustrações de Hildebrand (1954) para canídeos em geral, de Feeney (1999) para os canídeos silvestres Canis latrans, Urocyon cinereoargenteus e Vulpes vulpes e não-canídeos Martes pennanti e Procyon lotor e de Van Staden (2014) para Suricata suricatta. A nomenclatura adotada está em conformidade com o ICVGAN (2012), ainda que alguns acidentes relevantes que não constavam na Nomina Anatomica Veterinaria tenham sido denominados conforme apareceram no trabalho de Hildebrand (1954).

Osteometria com paquímetro. A osteometria foi realizada com paquímetro digital de precisão (resolução 0,01mm, exatidão $\pm 0,02 \mathrm{~mm}$, ZAAS Precision, Amatools ${ }^{\circledR}$ ), por dois examinadores em duplicata, conforme o roteiro de medidas internacionalmente preconizadas por Von-den-Driesch (1976) (Quadro 2). Também foram incluídas as medidas designadas por Samuels et al. (2013) para o cálculo de índices morfológicos com significado funcional (Quadro 3). Por fim, algumas medidas nos ossos carpianos e sesamoides foram elaboradas para o presente estudo. Todos os ossos foram mensurados em 16 espécimes de L. gymnocercus (sete fêmeas e nove machos), a exceção dos sesamoides que foram medidos em seis espécimes (três machos e três fêmeas). Um espécime fêmea de $C$. thous teve os ossos mensurados para obtenção dos índices morfológicos estabelecidos por Samuels et al. (2013). 0 software BioEstat $5.3^{\circledR}$ foi utilizado para: cálculo da estatística descritiva (média aritmética e desvio padrão) das medidas; teste t para comparação das médias das medidas dos ossos entre os sexos; e análise de variância (ANOVA: um critério) complementada pelo teste de Tukey para comparação do comprimento total dos dedos, diâmetro das falanges médias e do comprimento das falanges distais. Tais testes foram considerados significativos quando $\mathrm{p}<0,05$.

Osteometria tridimensional. Análises tridimensionais foram realizadas com o esqueleto do membro torácico do espécime 8576 (fêmea). Os ossos foram submetidos ao processo de digitalização em scanner 3D, Multiscan ${ }^{\circledR}$, para obtenção de um modelo tridimensional computadorizado com o software VXElements ${ }^{\circledR}$. Este modelo foi convertido para um formato compatível com softwares do tipo CAD ("computer aided design"), neste caso o SolidWorks ${ }^{\circledR}$, para mensurações tridimensionais. Assim puderam ser calculadas com precisão as áreas das superfícies articulares da escápula, úmero, rádio e ulna, bem como estabelecidos os posicionamentos tridimensionais das principais projeções ósseas em sistemas de coordenadas $\mathrm{x}$, y e $\mathrm{z}$ a partir de um marco pré-estabelecido.

Na escápula (Fig.1), o ponto "zero" do sistema de coordenadas foi definido como o ponto de interseção entre a espinha da escápula e a margem dorsal do osso, onde o eixo "X" era o látero-medial, o "Y" crânio-caudal e o "Z" dorso-ventral. No úmero (Fig.2), traçou-se um eixo látero-medial "X" ligando as extremidades dos epicôndilos lateral e medial; a partir do ponto médio deste eixo, projetou-se o eixo "Z" na direção proximal emergindo no tubérculo maior e o eixo "Y" perpendicularmente aos demais na direção crânio-caudal. No segmento contendo rádio, ulna e ossos da mão (Fig.3), traçou-se um eixo " $\mathrm{X}$ " entre as extremidades lateral e medial da epífise distal do rádio e ulna no sentido látero-medial; a partir do ponto médio deste eixo, projetou-se um eixo "Z" na direção proximal emergindo na tuberosidade do olecrano; e o eixo "Y" perpendicular aos outros dois, na direção crânio-caudal. Estes sistemas de eixos foram baseados naqueles traçados por Shahar \& Milgram (2005) em C. l. familiaris. Detalhes desta metodologia de osteometria tridimensional foram publicados por Ferreira et al. (2016).

Radiografias. Obtiveram-se imagens das regiões escapular, braquial, antebraquial e da mão em projeções usadas rotineiramente para investigações clínicas de dois espécimes (um macho

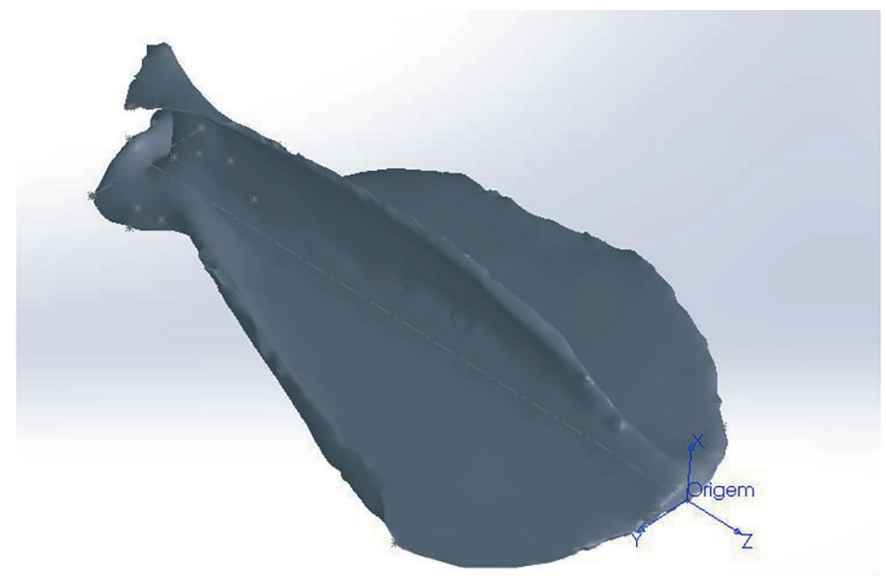

Fig.1. Modelo tridimensional da escápula esquerda de espécime fêmea, adulto, de Lycalopex gymnocercus evidenciando o marco zero no sistema de eixos para obtenção das coordenadas tridimensionais das projeções ósseas. 0 marco zero está definido na interseção da espinha da escápula com a margem dorsal. 0 eixo "X" encontra-se na direção médio-lateral, o eixo "Y" crânio-caudal e o eixo "Z" ventro-dorsal.

\section{Quadro 3. Índices morfométricos, definições e significados funcionais utilizados nos ossos do} membro torácico de carnívoros, conforme proposto por Samuels et al. (2013)

\begin{tabular}{|c|c|c|}
\hline Abreviatura & Índice & Significado \\
\hline $\begin{array}{l}\text { Índice momento do } \\
\text { ombro (SMI) - úmero }\end{array}$ & DPCL (úmero)/GL (úmero) & $\begin{array}{l}\text { Indica vantagem mecânica dos músculos peitoral e deltoide } \\
\text { atuando na articulação do ombro. }\end{array}$ \\
\hline Índice braquial (BI) & GL (rádio)/GL (úmero) & $\begin{array}{l}\text { Indica a proporção relativa dos elementos proximal e distal } \\
\text { do membro torácico. }\end{array}$ \\
\hline $\begin{array}{l}\text { Índice de robustez } \\
\text { umeral (HRI) }\end{array}$ & SD (úmero)/GL (úmero) & $\begin{array}{l}\text { Indica a robustez do úmero e sua capacidade de resistência } \\
\text { a estresse. }\end{array}$ \\
\hline $\begin{array}{l}\text { Índice epicondilar } \\
\text { umeral (HEI) }\end{array}$ & Bd (úmero)/GL (úmero) & $\begin{array}{l}\text { Indica a área relativa disponível para origem dos músculos } \\
\text { extensores, flexores, pronadores e supinadores no antebraço. }\end{array}$ \\
\hline $\begin{array}{l}\text { Índice comprimento } \\
\text { do olecrano (OLI) }\end{array}$ & ULOL (ulna)/FUL (ulna) & Indica a vantagem mecânica do m. tríceps braquial \\
\hline $\begin{array}{l}\text { Índice de robustez } \\
\quad \text { ulnar (URI) }\end{array}$ & UD (ulna)/FUL (ulna) & $\begin{array}{l}\text { Indica a robustez da ulna e sua capacidade para resistir } \\
\text { aos estresse e a área relativa para disponível para a origem e } \\
\text { inserção dos músculos flexores, pronadores e supinadores. }\end{array}$ \\
\hline $\begin{array}{l}\text { Índice de proporção } \\
\text { da mão (MANUS) }\end{array}$ & FPIIIGL/MCIIIGL & $\begin{array}{l}\text { Indica as proporções relativas entre os elementos proximal e } \\
\text { distal da mão e tamanho da superfície palmar. }\end{array}$ \\
\hline
\end{tabular}




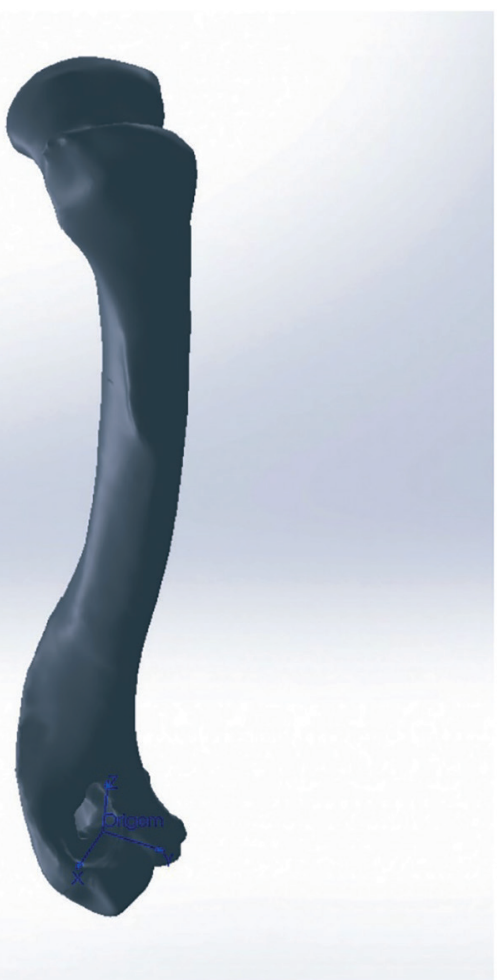

Fig.2. Modelo tridimensional do úmero direito de espécime fêmea, adulto, de Lycalopex gymnocercus evidenciando o marco zero no sistema de eixos para obtenção das coordenadas tridimensionais das projeções ósseas. 0 marco zero está definido no ponto médio do eixo " $\mathrm{X}$ " traçado médio-lateralmente entre as extremidades dos dois epicôndilos. 0 eixo "Y" encontra-se na direção caudo-cranial e o eixo "Z" na direção disto-proximal.

e outro fêmea). Foram escolhidos adultos jovens para que os discos epifisários cartilagíneos pudessem ser visualizados. Com base na dentição completa e permanência de alguns discos epifisários cartilagíneos e dos tempos de fechamento epifisário conhecidos para C. l. familiaris (Evans \& De Lahunta 2013), presumiu-se que os cadáveres eram de animais entre sete e dez meses de idade.

Posteriormente radiografaram-se os ossos escápula, úmero, rádio e ulna isolados e limpos de três espécimes (dois machos e uma fêmea) em quatro projeções (crânio-caudal, caudo-cranial, látero-medial e médio-lateral) para evidenciar o contorno e padrões trabeculares livres de sobreposição de tecidos moles ou outros ossos.

As imagens foram obtidas no setor de diagnóstico por imagem do Hospital Veterinário da Universidade Federal do Pampa (Unipampa), respeitando-se as diretrizes básicas de proteção radiológica (CNEN 2014). Empregou-se a técnica de chassi sobre a mesa. As radiografias foram obtidas com o aparelho marca Phillips ${ }^{\circledR}$, modelo Aquilla Plus 300, utilizando $40 \mathrm{KV}$ e $200 \mathrm{mAs}$ para os cadáveres inteiros e $40 \mathrm{mAs}$ para os ossos isolados. As exposições foram realizadas em sistema de cassete computadorizado da marca Kodak ${ }^{\circledR}$ Direct View e salvas no formato DICOM. Após visualização em software Radiant Dicom Viewer ${ }^{\circledR,}$, versão 3.0.2, os arquivos foram exportados para formato JPEG. As representações esquemáticas interpretativas a partir dos contornos das imagens radiográficas dos membros torácicos inteiros foram elaboradas com auxílio do software Photoscape ${ }^{\circledR}$ versão 3.6.3.

Clavículas. As clavículas de onze espécimes (sete machos e quatro fêmeas) de cadáveres de L. gymnocercus fixados e conservados em solução de formaldeído a $10 \%$ foram removidas e identificadas após dissecção da região profunda à intersecção ten-

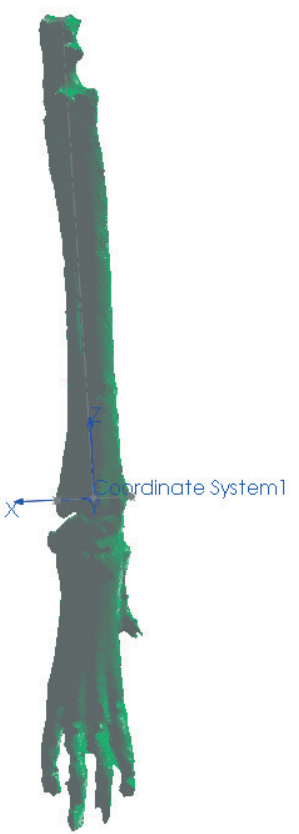

Fig.3. Modelo tridimensional do rádio e ulna esquerdo de espécime fêmea, adulto, de Lycalopex gymnocercus evidenciando o marco zero no sistema de eixos para obtenção das coordenadas tridimensionais das projeções ósseas. 0 marco zero está definido no ponto médio do eixo "X" traçado médio-lateralmente entre as extremidades da região distal do rádio e da ulna. 0 eixo "Y" encontra-se na direção crânio-caudal e o eixo "Z" na direção disto-proximal.

dinosa do $\mathrm{m}$. braquiocefálico. As clavículas tiveram seu formato registrado e o seu maior eixo mensurado com paquímetro digital de precisão (resolução $0,01 \mathrm{~mm}$, exatidão $\pm 0,02 \mathrm{~mm}$, ZAAS Precision, Amatools ${ }^{\circledR}$ ), por examinador único em duplicata e, posteriormente encaminhadas para a avaliação histológica. As clavículas foram clivadas sagitalmente, embebidas em parafina e as seções histológicas com $4 \mu \mathrm{m}$ submetidas à coloração por hematoxilina e eosina. As lâminas com cortes histológicos foram examinadas em microscópio óptico de luz quanto às características constitutivas das clavículas. Finalmente fotomicrografias digitais foram realizadas com câmera Olympus ${ }^{\circledR}$ DP26 associada ao software cellSens $1.7^{\circledR}$. As clavículas de 20 espécimes de $C$. thous (sete machos e treze fêmeas) pertencentes ao acervo do Laboratório foram analisadas da mesma forma para fins de comparação. As medidas foram tabuladas em planilhas do software BioEstat $5.3^{\circledR} \mathrm{e}$ realizados os cálculos de estatística descritiva (média aritmética e desvio padrão) e teste t (amostras independentes) de comparação entre as médias dos comprimentos das clavículas entre espécies e entre sexos, adotando-se p < 0,05 como significativo. Doze clavículas de cada espécie foram escolhidas aleatoriamente para radiografias com o objetivo de verificar a presença e o grau de radiopacidade.

\section{RESULTADOS E DISCUSSÃO}

\section{Constituição geral}

0 esqueleto do membro torácico de Lycalopex gymnocercus foi composto por uma clavícula rudimentar, uma escápula, um úmero, um rádio, uma ulna, sete ossos carpianos, cinco ossos metacarpianos, 14 falanges, um osso sesamoide do m. supinador, um osso sesamoide do m. abdutor longo do dedo I, nove ossos sesamoides proximais, quatro ossos sesamoides dorsais, totalizando 46 ossos in- 


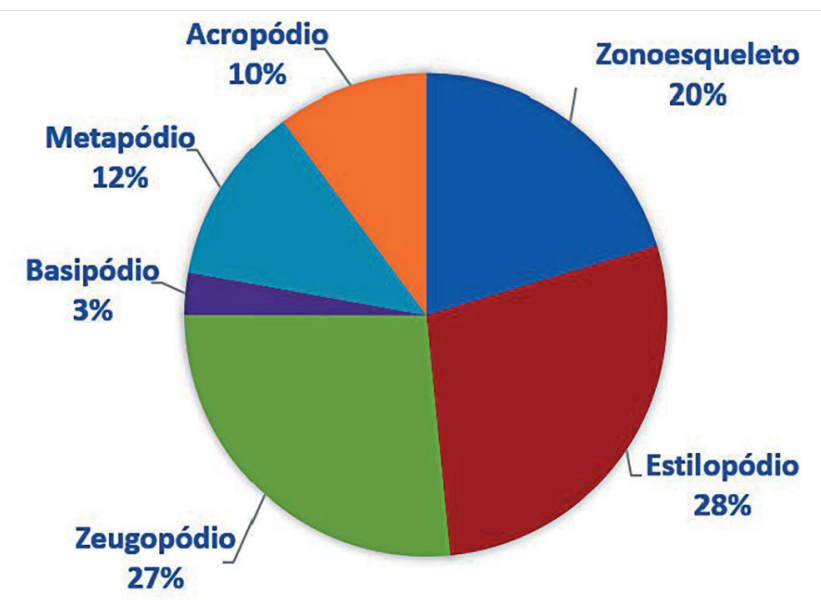

Fig.4. Gráfico com o percentual médio dos comprimentos de cada segmento do membro torácico dos dezesseis espécimes de Lycalopex gymnocercus. 0 zonoesqueleto foi representado pela altura da escápula, o estilopódio pelo comprimento do úmero, o zeugopódio pelo comprimento do rádio, o basipódio pela soma das alturas dos ossos carpianos intermédio-radial e terceiro, o metapódio pelo comprimento do metacarpiano terceiro e o acropódio pela soma dos comprimentos das falanges do terceiro dedo.

variavelmente presentes. Um número inconstante de ossos sesamoides distais e nas articulações interfalangianas com diferentes graus de mineralização foi encontrado.

O comprimento longitudinal total do membro torácico, estimado com base na soma das médias dos comprimentos da escápula, úmero, rádio, carpo intermédio-radial, carpiano terceiro, metacarpiano terceiro e falanges do terceiro dedo, foi $430,18 \pm 12,82 \mathrm{~mm}$, sendo $423,39 \pm 13,74 \mathrm{~mm}$ nas fêmeas e $435,27 \pm 10,06 \mathrm{~mm}$ nos machos. Embora a média da soma dos comprimentos nos machos fosse $12 \mathrm{~mm}$ maior, não houve diferença significativa $(\mathrm{p}=0,09)$. Percentualmente, pode-se constatar que o úmero (estilopódio) foi o osso que mais contribuiu (28\%) para o comprimento do membro (Fig.4). Ainda que a ulna tenha sido o osso mais longo, não foi computada para fins de comprimento funcional do membro pois o seu olecrano sobrepõe-se proximalmente a partir da articulação úmero-radio-ulnar e, portanto, foi considerado apenas o comprimento do rádio como representante do segmento antebraquial (zeugopódio).

\section{Clavículas}

As clavículas, ainda que rudimentares, foram encontradas bilateralmente em todos os espécimes dissecados de $L$. gymnocercus (sete machos e quatro fêmeas) e de Cerdocyon thous (sete machos e treze fêmeas), ainda que Ewer (1973) e Nickel et al. (1986) tenham mencionado que frequentemente estão ausentes em canídeos. Localizava-se profundamente ao músculo braquiocefálico, ao nível da intersecção tendinosa que separa o músculo em cleidocefálico e cleidobraquial (Fig.5). Esta disposição é diferente da relatada por Nickel et al. (1986) e Sisson (1986) para C. l. familiaris, em que a clavícula ficaria encaixada no $\mathrm{m}$. braquiocefálico. O formato das clavículas mostrou variação intra-específica, assim como relatado por Nickel et al. (1986) para C. l. familiaris. Contudo, predominou um formato triangular irregu-

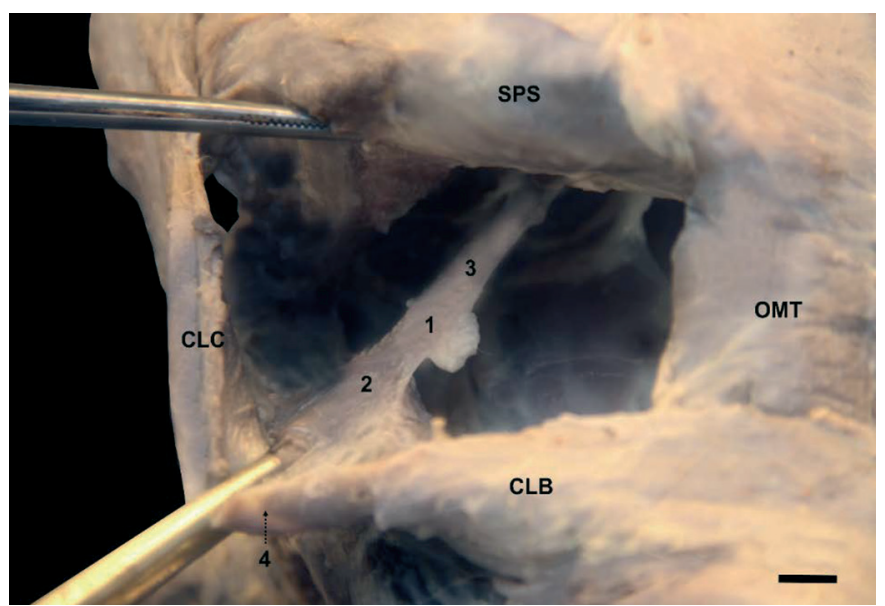

Fig.5. Fotomacrografia em vista crânio-lateral da região escápulo-umeral de espécime fêmea de Lycalopex gymnocercus, adulto, evidenciando a clavícula (1) fixa cranialmente pelas bandas fibrosas ( 2 e 3) direcionadas cranialmente à intersecção tendínea (4) e caudalmente à fáscia do m. subescapular. M. supra-espinhal (SPS), m. omotransverso (OMT), m. cleidobraquial (CLB) e m. cleidocefálico (CLC). Barra $=10 \mathrm{~mm}$.

lar com as formas ovaladas ou de "ferradura" aparecendo ocasionalmente. Segundo Černý \& Čižinauskas (1995) o formato predominante em C. l. familiaris é o ovalado. Estes autores especularam que variações nos formatos das clavículas em cães possa advir das modificações e reduções que a mesma sofre durante a ontogenia. Assim, concluíram que a clavícula seria uma estrutura que passa por regressão em diferentes níveis em um processo individualizado. A clavícula de cães permanece ossificada durante o período fetal, diferente dos ruminantes em que a redução ocorre ainda durante a gestação (Evans \& DeLahunta 2013). McCarthy \& Wood (1988) investigaram clavículas de cinquenta $C$. $l$. familiaris e relataram um cão sem evidência de clavículas bilateralmente e outros dois em que faltava uma das duas clavículas.

A parte rígida (óssea) da clavícula mantinha-se ligada por uma banda espessa de tecido conjuntivo que se prolongava craniolateralmente na direção da intersecção clavicular e medialmente em direção à fáscia do $\mathrm{m}$. subescapular, conforme descrito por Baum \& Zietzschmann (1936) e Černý \& Čižinauskas (1995) para C. l. familiaris. Da mesma forma, a conexão com a intersecção tendinosa foi mais firme do que com a fáscia muscular (Evans \& DeLahunta 2013). McCarthy \& Wood (1988) também descreveram uma faixa fibrosa mais espessa em C. l. familiaris, embora acrescentem outros fascículos fibrosos menores em direção ao manúbrio, à fáscia do m. grande dorsal e do m. peitoral superficial. Estes pequenos fascículos não foram claramente individualizados nos canídeos silvestres do presente estudo, assim como Černý \& Čižinauskas (1995) também não os identificaram em cães recém-nascidos. As clavículas de L. gymnocercus e de C. thous não estabeleceram articulação com nenhum outro osso, assim como observado por Sisson (1986) e Evans \& DeLahunta (2013).

As clavículas de L. gymnocercus mediram $7,0 \pm 1,4 \mathrm{~mm}$ no seu maior eixo, sendo $7,7 \pm 1,2 \mathrm{~mm}$ nos machos e $5,9 \pm 0,9 \mathrm{~mm}$ nas fêmeas, existindo diferença significativa $(p=0,02)$ en- 


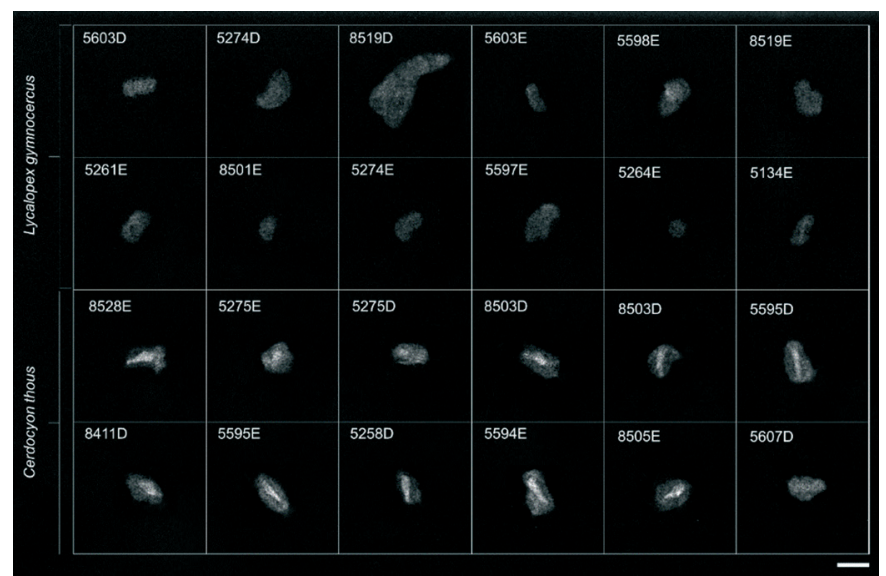

Fig.6. Imagem radiográfica das clavículas individualizadas de doze espécimes de Lycalopex gymnocercus e doze de Cerdocyon thous. 0 número de registro do espécime está acompanhado das letras D (direita) ou E (esquerda). Observar a radiopacidade característica de tecido ósseo em meio a tecido fibroso das clavículas de Cerdocyon thous e a ausência deste padrão no Lycalopex gymnocercus.

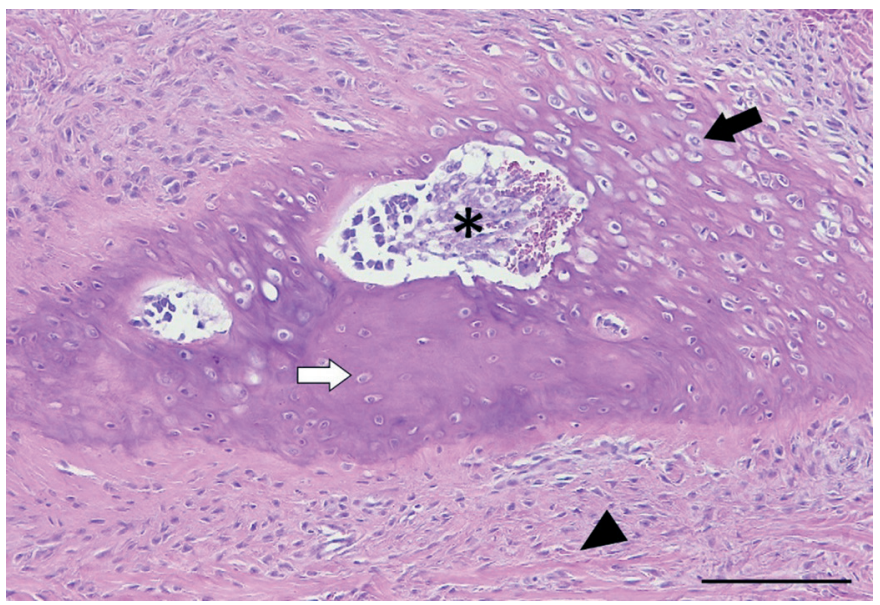

Fig.7. Seção histológica da clavícula esquerda de espécime fêmea, adulto, de Lycalopex gymnocercus evidenciando extensa área de matriz cartilagínea hialina, caracterizada por condrócitos maduros no interior de lacunas (seta preta) e uma pequena área de matriz osteoide (seta branca). Centralmente percebe-se uma lacuna óssea contendo tecido mieloides, capilares e célula osteoclástica $(*)$. Observa-se grande quantidade de fibras colágenas/elásticas circundando essas áreas. Esse tecido se caracteriza por células com núcleo alongado e ou triangular semelhante a fibroblastos e células condroides imaturas com formação do pericôndrio (cabeça de seta). Hematoxilina e eosina. Material não descalcificado. Barra $=100 \mu \mathrm{m}$.

tre os sexos. As clavículas de C. thous mediram 9,6 $\pm 1,4 \mathrm{~mm}$, sendo $10,1 \pm 1,4 \mathrm{~mm}$ nos machos e $9,0 \pm 1,3 \mathrm{~mm}$ nas fêmeas, sem diferença entre sexos $(p=0,13)$. 0 comprimento da clavícula de $C$. thous foi significativamente maior que o de L. gymnocercus $(\mathrm{p}<0,0001)$. Em canídeos silvestres os relatos sobre as dimensões das clavículas são escassos. Contudo, é citada como medindo $15 \mathrm{~mm}$ em Lycaon pictus (Pagenstretcher 1870), 10mm em Vulpes fulva (Klatt 1928) e $11 \mathrm{~mm}$ em C. l. familiaris (Hildebrand 1954). Em C. l. familiaris mediu entre 6 e $12 \mathrm{~mm}$ e cerca de $13 \mathrm{~mm}$ na raça
Dinamarquês (McCarthy \& Wood 1988) e entre 1 e $2 \mathrm{~mm}$ em cães recém-nascidos (Černý \& Čižinauskas 1995).

$\mathrm{Na}$ exploração radiográfica em projeção látero-medial do membro torácico de dois cadáveres de L. gymnocercus, recém-descongelados e previamente à fixação em formaldeído, não foi possível visualizar as clavículas. No entanto, após fixação em formol e dissecção destes dois espécimes, confirmou-se a existência bilateral das mesmas. Também é relatada como imperceptível em radiografias látero-mediais de C. l. familiaris, ainda que possa aparecer em projeções ventro-dorsais do pescoço ou tórax (Evans \& DeLahunta 2013).

Quando as clavículas de L. gymnocercus foram radiografadas após removidas dos cadáveres, praticamente não foi possível identificar radiopacidade característica de tecido ósseo. Entretanto, ao contrário, todas as clavículas de $C$. thous evidenciaram nítida radiopacidade capaz de revelar inclusive o formato do osso (Fig.6). Esta radiopacidade foi compatível com o revelado por McCarthy \& Wood (1988) para cães de raças Terriers e Dinamarquês. Em C. l. familiaris, sinais radiodensos compatíveis com ossificação da clavícula são encontrados mesmo em neonatos (Černý \& Čižinauskas 1995, Evans \& DeLahunta 2013).

A análise histológica esclareceu que todas as clavículas dos onze espécimes de L. gymnocercus eram constituídas predominantemente por matriz condroide e apenas uma pequena parte por matriz osteoide (Fig.7). Em contrapartida, as clavículas dos vinte espécimes de $C$. thous eram formadas integralmente por tecido ósseo com raros condrócitos (Fig.8). A avaliação histológica elucidou o contraste observado entre as clavículas das duas espécies na inspeção macroscópica, na rigidez palpável durante a dissecção da amostra e de radiopacidade nos exames radiográficos.

Segundo Donat (1971) a clavícula está presente em praticamente todos os gêneros de mamíferos e a importância

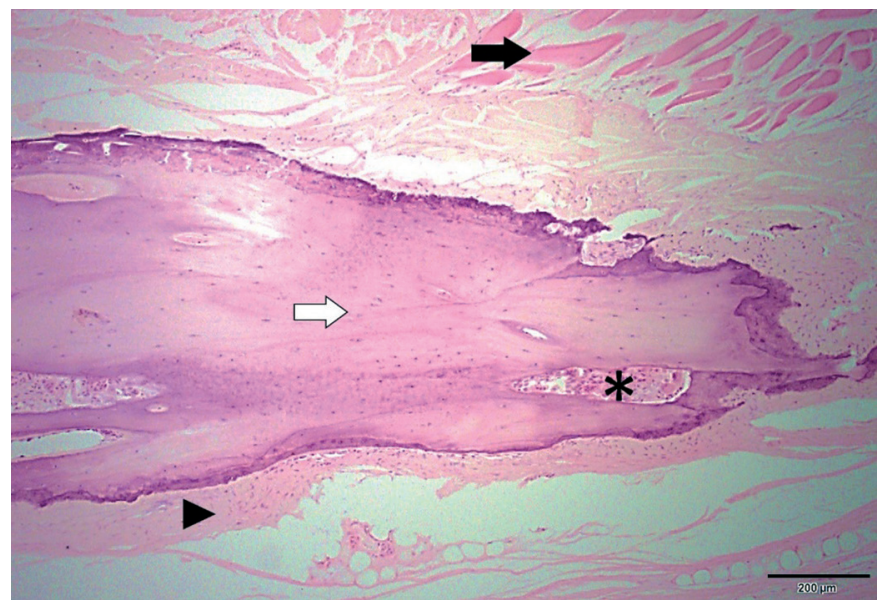

Fig.8. Seção histológica da clavícula esquerda de espécime fêmea, adulto, de Cerdocyon thous evidenciando extensa área de matriz osteoide madura com numerosos osteócitos encarcerados na matriz (seta branca). Em meio ao tecido ósseo nota-se uma lacuna preenchida por células mieloides $(*)$. Toda a clavícula é circundada por tecido conjuntivo denso (cabeça de seta) e mais externamente notam-se fibras musculares esqueléticas (seta preta). Hematoxilina e eosina. Material não descalcificado. Barra $=200 \mu \mathrm{m}$. 
funcional sobrepõe-se a questões filogenéticas. Este autor argumentou que a permanência de uma clavícula rudimentar com suas estruturas anexas manteria a parte proximal do membro mais fixa e liberaria a parte distal para mover-se livremente. Quando confrontados o tamanho e grau de ossificação, a clavícula de L. gymnocercus foi ainda menos desenvolvida (mais rudimentar) que a de C. thous e C. l. familiaris. Embora estas três espécies apresentem clavículas vestigiais, isto pode sugerir que a clavícula mais reduzida e menos ossificada de L. gymnocercus reflita uma tendência evolutiva ou adaptação para a locomoção ainda mais rápida.

Samuels et al. (2013) estabeleceram uma classificação das espécies carnívoras quanto ao tipo de locomoção. Naquele trabalho, L. gymnocercus foi enquadrado na categoria cursorial especializado, ou seja, uma espécie que regularmente apresenta locomoção rápida com um saltitar caracterizado por intervalos sem apoio no solo. Já $C$. thous foi classificado como terrestre generalista, isto é, que permanece no solo, porém muito eventualmente pode nadar, escalar ou escavar. Esta correlação entre clavícula menos desenvolvida com maior velocidade e mais desenvolvida com movimentos mais variados do membro torácico é feita em carnívoros (Ewer 1973) e outras ordens de mamíferos (Rocha-Barbosa et al. 2002, Senter \& Moch 2015). A redução da clavícula em várias linhagens de mamíferos permite à escápula mover-se mais livremente no plano sagital e, consequentemente, contribui para uma passada maior (Martín-Serra et al. 2015), bem como permite uma maior aproximação do membro no plano sagital, elevando o centro de gravidade do animal e desta forma aumentando a sua manobrabilidade (Rocha-Barbosa et al. 2002).

McCarthy \& Wood (1988) acrescentaram que a clavícula de cães facilitaria o movimento durante a protração, retração e discreta abdução do ombro, protegeria estruturas adjacentes como o plexo braquial, artéria, veia e nervo axilares do contato com o m. subescapular e escápula; e manteria o $\mathrm{m}$. braquiocefálico na posição adequada, conferindo proteção para crista do tubérculo maior. De acordo com Senter \& Moch (2015), entre carnívoros, apenas canídeos e felídeos retêm uma clavícula vestigial com uma pequena parte ossificada, a qual representa um resquício degenerado de uma clavícula ancestral. Estes autores determinaram que a distribuição filogenética da clavícula indica que a mesma foi perdida no ancestral comum dos hienídeos e no dos ursídeos, mustelídeos e procionídeos. Corrobora esta inferência a sua ausência no Suricata suricatta (Van Staden 2014).

Ainda que diferenças constitutivas sejam observadas entre as clavículas de L. gymnocercus, C. thous e C. l. familiaris, cabe salientar que é improvável que este osso tenha características de valor taxônomico devido às variações, tamanho reduzido e por raramente ser preservada em esqueletos preparados para estudo (Hildebrand 1954).

\section{Escápula (Zonoesqueleto)}

A escápula mostrou-se plana e larga e composta por duas faces (lateral e medial), três margens (cranial, caudal e dorsal) e três ângulos (cranial, caudal e ventral). Sua parte mais dorsal, o ângulo cranial, coincidiu com o nível da extremidade dorsal do processo espinhoso da segunda vér-
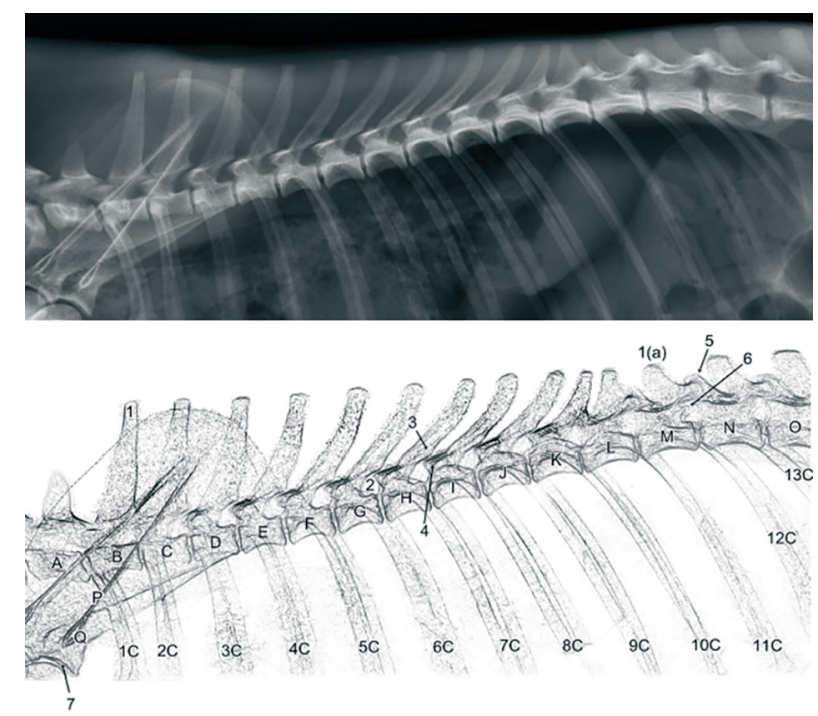

Fig.9. Radiografia (acima) e representação esquemática (abaixo) da região escapular e coluna vertebral torácica de espécime macho de Lycalopex gymnocercus em projeção lateral revelando o processo espinhoso da primeira vértebra torácica (1), décima segunda vértebra torácica (1a), forame intervertebral (2), processo articular caudal da sétima vértebra torácica (3), processo articular cranial da oitava vértebra torácica (4), processo mamilar (5), processo acessório (6), cavidade glenoide (7), sétima vértebra cervical a primeira vértebra lombar (A a $\mathbf{0}$ ), espinha da escápula (P), acrômio (Q) e os pares de costelas (1C a 13C). Observar a topografia do ângulo cranial da escápula dorsal ao ângulo caudal.

tebra torácica (Fig.9). 0 ângulo caudal ficou ao nível ventral do processo espinhoso da quarta vértebra torácica. Seu ângulo cranial esteve dorsal em relação ao caudal. Seu extremo cranial dispunha-se no plano transversal do manúbrio e seu extremo caudal no plano da quarta vértebra torácica.

As escápulas de L. gymnocercus e de $C$. thous podem ser consideradas finas e compridas quando comparadas ao que é ilustrado para carnívoros em geral por Ewer (1973). Segundo Martín-Serra et al. (2014), após análises alométricas e de morfometria geométrica, escápulas com o formato mais estreito e alongado ocorrem em carnívoros menores, os quais necessitam reduzir o gasto energético da locomoção. Para os canídeos, isto seria favorável para alcançar maiores distâncias diárias de deslocamento, por exemplo. Aquelas com formato mais robusto pertenceriam às espécies de maior tamanho corporal, que capturam presas maiores, escavam ou nadam. Estes não são movimentos frequentes em L. gymnocercus que tem o esqueleto apendicular mais delgado, inclusive, que outros canídeos (Hildebrand 1954). ${ }^{6}$

De fato, a escápula é o osso do membro torácico que menos varia entre espécies de uma mesma família de carnívoros (Martín-Serra et al. 2014). Isto explica-se por se tratar de um osso do cinturão peitoral e que tem uma origem e história evolutiva diferente dos ossos longos do mem-

\footnotetext{
${ }^{6}$ Hildebrand (1954) mencionava o atual Lycalopex gymnocercus como Dusicyon gymnocercus e usava o gênero Lycalopex apenas para a espécie Lycalopex vetulus. Quando Hildebrand (1954) mencionara o gênero Dusicyon, entende-se atualmente como Lycalopex. Portanto, diferença será encontrada no emprego do gênero em relação ao texto original do referido autor.
} 


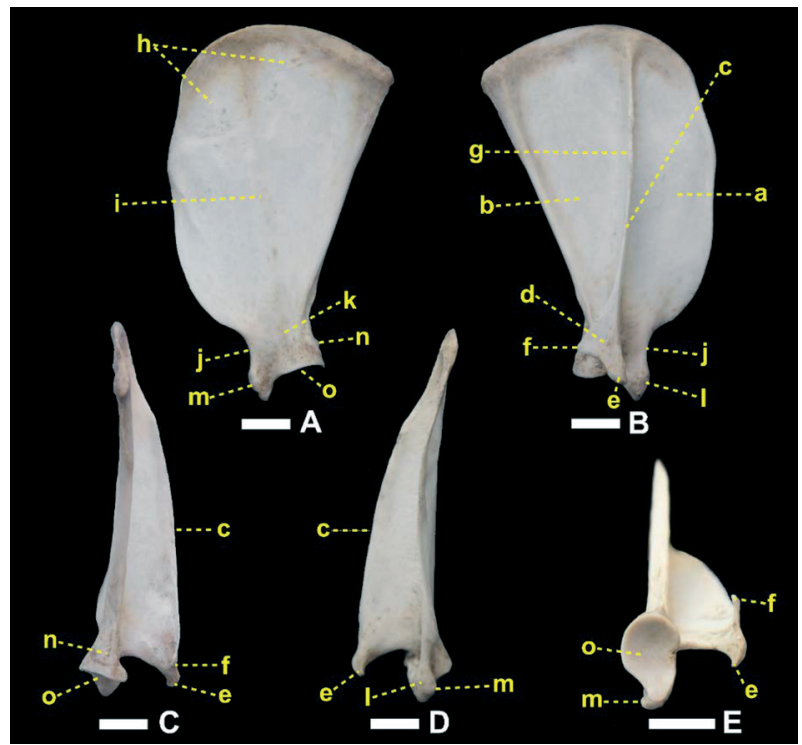

Fig.10. Fotomacrografias da escápula direita de um espécime macho adulto de Lycalopex gymnocercus em vistas medial (A), lateral (B), caudal (C), cranial (D) e ventral (E) evidenciando a fossa supra-espinhal (a), fossa infra-espinhal (b), espinha da escápula (c), acrômio (d), processo hamato (e), processo supra-hamato (f), tuberosidade da espinha da escápula (g), face serrátil (h), fossa subescapular (i), incisura escapular (j), colo da escápula (k), tubérculo supraglenoide (1), processo coracoide (m), tubérculo infraglenoide (n), cavidade glenoide (o), Barra $=10 \mathrm{~mm}$.

bro, os quais estão mais expostos a variação de robustez (Martín-Serra et al. 2014).

A face lateral (facies lateralis) foi dividida em duas fossas (supraspinata e infraspinata) pela espinha da escápula (spina scapulae) (Fig.10). A osteometria tridimensional permitiu apurar que a fossa supra-espinhal de L. gymnocercus compôs $52 \%$ e a infra-espinhal $48 \%$ da área da face lateral do osso, o que confirmou o equilíbrio entre ambas relatado em carnívoros por Nickel et al. (1986). As fossas supra-espinhais de L. gymnocercus e de C. thous foram mais amplas no terço ventral do que no cão. Talvez isto repercuta em um m. supra-espinhoso proporcionalmente mais forte nos canídeos silvestres. A fossa infra-espinhal foi triangular tanto em L. gymnocercus como em C. thous, assim como em C. l. familiaris (Evans \& DeLahunta 2013). Ela serviu de origem para o $\mathrm{m}$. infra-espinhoso.

A espinha da escápula era uma elevação não-articular, proeminente na face lateral do osso. Dorsalmente foi mais discreta e elevava-se na direção ventral. No nível do ângulo ventral terminou em um acrômio (acromion) contendo dois processos: hamato e supra-hamato. Foi reconhecido no terço dorsal uma aspereza discreta, a tuberosidade da espinha da escápula (tuberosita spina scapulae) para inserção do m. trapézio, embora Nickel et al. (1986) tenham afirmado que tal tuberosidade inexista nos carnívoros domésticos. Tanto L. gymnocercus, como também o $C$. thous, apresentaram a margem livre da espinha da escápula retilínea, diferente do descrito para cães de grande porte onde tal margem se voltaria caudalmente (Evans \& DeLahunta 2013). Ainda que estas diferenças sejam apontadas, segundo Hildebrand (1954) o formato da espinha da escápula não tem valor na diferenciação entre os gêneros de canídeos.
0 processo hamato de C. l. familiaris é arredondado à semelhança do ilustrado por Feeney (1999) para Vulpes vulpes e Canis latrans; em C. thous é levemente pontiagudo direcionado ventralmente, assim como descrito em Urocyon cinereoargenteus (Hildebrand 1954, Feeney 1999). Em Martes pennanti e em Procyon lotor é ainda mais pontiagudo também na direção ventral (Feeney 1999). Em L. gymnocercus mostrou-se pontiagudo e bem distinto, conforme descrito por Hildebrand (1954), porém direcionado mais cranioventralmente, uma configuração não mencionada para outros canídeos.

0 processo supra-hamato foi mais desenvolvido em L. gymnocercus do que em C. thous. Feeney (1999) e Martín-Serra et al. (2014) denominaram-no como processo metacromial. Feeney (1999) correlacionou sua formação como reflexo do desenvolvimento do $\mathrm{m}$. omotransverso, o que favoreceria a protração do membro, especialmente em U. cinereoargenteus. Martín-Serra et al. (2014) afirmaram esta ser uma característica mais proeminente nos felídeos e que poderia estar associada a uma parte acromial do m. deltoide mais desenvolvida e necessária para contrapor as forças de reação do solo durante a locomoção. Entre carnívoros, o processo supra-hamato não é reconhecido em $C$. $l$. familiaris (ICVGAN 2012), no gênero Speothos (Hildebrand 1954), considerado pouco desenvolvido em $V$. vulpes, C. latrans (Feeney 1999), Chrysocyon brachyurus e Lycaon pictus (Hildebrand 1954) e considerado como bem desenvolvido nos felinos (ICVGAN 2012, Martín-Serra et al. 2014), em $U$. cinereoargenteus (Hildebrand 1954, Feeney 1999), M. pennanti, P. lotor (Feeney 1999) e S. suricatta (Van Staden 2014).

Nos espécimes de L. gymnocercus sempre foi visualizado um forame nutrício (principal) na face medial ao nível da incisura da escápula, ainda que alguns forames vasculares menores e inconstantes ocorressem na face lateral, próximo à junção ventral da espinha com a escápula propriamente. Esta última localização foi descrita para o forame nutrício no cão (Evans \& DeLahunta 2013). Em C. thous, o forame nutrício, mais largo, foi encontrado na mesma localização descrita para o cão, ainda que um forame de calibre destacado também fosse visualizado medialmente, conforme em L. gymnocercus. É possível que os forames lateral e medial formem um canal para a passagem de um ramo da artéria subescapular.

A face medial (facies medialis ou costalis) voltou-se opostamente à face lateral das primeiras quatro costelas em L. gymnocercus. Nela encontraram-se dois acidentes principais: a face serrátil (facies serrata) e a fossa subescapular (fossa subscapularis). A face serrátil era áspera, dorsocranialmente na face medial, e servia de inserção para o m. serrátil ventral. 0 limite caudal da face serrátil esteve ao nível ligeiramente caudal à espinha, tanto em L. gymnocerus quanto em $C$. thous. Em C. l. familiaris, termina mais caudalmente que em ambos (Evans \& DeLahunta 2013). Em L. pictus este limite caudal da face serrátil é tão caudal quanto o ângulo caudal da escápula (Hildebrand 1954). A fossa subescapular apresentou três linhas musculares que convergiram na direção do ângulo ventral e a parte mais profunda da fossa esteve central e opostamente à espinha.

A margem cranial (margo cranialis) era fina, quase retilínea, e distalmente possuía uma incisura escapular (in- 
cisura scapulae) a qual definiu uma região mais estreita no sentido crânio-caudal do osso: o colo da escápula (collum scapulae). Em C. l. familiaris, Evans \& DeLahunta (2013) relataram que a margem cranial assume a forma de um arco nas raças de trabalho e Hildebrand (1954) referiu este contorno para o C. brachyurus. Um contorno mais retilíneo e suave foi descrito para as raças de cães mais longilíneas (Evans \& DeLahunta 2013) e para os canídeos cursoriais especializados $V$. vulpes, V. lagopus e C. latrans (Hildebrand 1954). Em L. gymnocercus e C. thous o padrão assemelhou-se ao último. Segundo Hildebrand (1954), em L. gymnocercus haveria também uma elevação no centro da margem cranial, assim como nos gêneros Otocyon e Urocyon. Ainda descreveu que em $C$. thous esta elevação ocorreria no terço ventral, porém tais observações não se repetiram nos espécimes avaliados no presente trabalho.

A margem dorsal (margo dorsalis ou margo vertebralis) foi recoberta por uma fina camada de cartilagem escapular (cartilago scapulae). Em um espécime fêmea de L. gymnocercus a cartilagem mediu $1,93 \mathrm{~mm}$ de espessura dorso-ventral. Em L. gymnocercus a margem dorsal teve o contorno mais arqueado/convexo do que em $C$. thous e $C$. $l$. familiaris (mais achatado). No gênero Speothos foi descrita como reta (Hildebrand 1954).

A margem caudal das escápulas do L. gymnocercus e $C$. thous foram retas e espessas, assim como descrito para $C$. l. familiaris (Sisson 1986) e também apresenta um espessamento proximal à cavidade glenoide, o tubérculo infraglenoide (tuberculum infraglenoidale) (Nickel et al. 1986). Tanto em L. gymnocercus como em C. thous este tubérculo pareceu menos robusto que no cão.

O ângulo caudal (angulus caudalis) da escápula do $L$. gymnocercus foi mais pontiagudo que do $C$. thous e em ambas mais afiladas que em C. l. familiaris. Distalmente ao ângulo há uma superfície para a origem do m. redondo maior. Segundo Hildebrand (1954), como regra esta superfície é sempre retorcida, sendo sua parte dorsal melhor visualizada pela face lateral e a parte ventral pela medial. Entretanto, nos gêneros Chrysocyon e Cuon apareceria inteiramente na face lateral do osso, enquanto em L. gymnocercus, $C$. thous e Vulpes macrotis dificilmente esta área seria vista pela face lateral (Hildebrand 1954). No gênero Speothos esta superfície seria discreta (Hildebrand 1954). Ainda acrescentou que esta superfície para origem do m. redondo maior constituía-se na principal característica para diferenciar os gêneros de canídeos pela escápula. Esta afirmação não encontrou apoio nas observações das escápulas dos espécimes do presente estudo, em que a área de origem para o m. redondo maior era visualizada pela face lateral do osso, especialmente em L. gymnocercus. 0 ângulo cranial (angulus cranialis) tinha contorno arredondado e não sediou fixação muscular.

0 ângulo ventral (angulus ventralis) conteve a superfície articular para a cabeça do úmero, denominada cavidade glenoide (cavitas glenoidalis). A cavidade tinha discreta concavidade e foi delimitada cranialmente pelo tubérculo supraglenoide. A margem caudomedial da cavidade foi arredondada, enquanto a margem lateral era mais retilínea, conforme o cão. Na osteometria tridimensional foi possível estimar que a área total da escápula era de $8714,27 \mathrm{~mm}^{2}$ e a sua
Quadro 4. Localização dos principais acidentes anatômicos da escápula de um espécime fêmea de Lycalopex gymnocercus em sistema de eixo de coordenadas

\begin{tabular}{lccc}
\hline Acidente anatômico & $\begin{array}{c}\text { Eixo X } \\
(\mathrm{mm})\end{array}$ & $\begin{array}{c}\text { Eixo Y } \\
(\mathrm{mm})\end{array}$ & $\begin{array}{c}\text { Eixo Z } \\
(\mathrm{mm})\end{array}$ \\
\hline Ângulo caudal & 5,90 & 35,57 & $-13,45$ \\
Ângulo cranial & 0,31 & $-12,32$ & $-5,68$ \\
Processo hamato & 15,37 & $-2,07$ & $-82,96$ \\
Processo supra-hamato & 16,34 & 9,50 & $-78,25$ \\
Limite cranial do colo & 0,67 & $-7,77$ & $-77,01$ \\
Limite caudal do colo & 1,18 & 7,50 & $-73,98$ \\
Processo coracoide & $-2,19$ & $-7,48$ & $-81,38$ \\
Ponto mais lateral da espinha & 16,93 & 3,05 & $-61,70$ \\
Tubérculo supraglenoide & 0,00 & $-9,03$ & $-82,60$ \\
Ponto mais ventral da espinha & 3.61 & 0.62 & $-78,49$ \\
Extremo lateral da cavidade glenoide & 5,14 & 3,32 & $-82,96$ \\
Extremo medial da cavidade glenoide & $-5,48$ & 1,75 & $-82,21$ \\
Tubérculo infraglenoide & $-2,61$ & 7,66 & $-78,41$ \\
Extremidade ventral do processo coracoide & $-0,75$ & $-6,38$ & $-87,47$
\end{tabular}

cavidade glenoide ocupava $129,61 \mathrm{~mm}^{2}(1,4 \%$ da área total do osso). A posição dos principais acidentes anatômicos em um eixo de coordenadas X, Y e Z encontra-se no Quadro 4.

0 tubérculo supraglenoide (tuberculum supraglenoidale) projetou-se cranialmente. A partir dele, medialmente, formou-se um pequeno processo coracoide (processus coracoideus). Tal processo corresponde ao osso coracoide dos répteis, incluindo as aves. Os monotremados são os únicos mamíferos a conservarem um osso coracoide distinto (Evans \& DeLahunta 2013, Liem et al. 2013).

Segundo Hildebrand (1954) o conjunto formado pela cavidade glenoide, tubérculo supraglenoide (tuberosidade escapular) e processo coracoide é muito uniforme entre os canídeos para ser adotado como critério de distinção entre gêneros. Entretanto, o processo coracoide nas escápulas dos espécimes de $C$. thous do presente estudo mostraram-se mais salientes e o tubérculo supraglenoide maior que os de L. gymnocercus e C. l. familiaris.

Todas as escápulas utilizadas nesta análise apresentavam o tubérculo supraglenoide ossificado. Caso o tempo de ossificação seja equivalente ao do cão, pode-se especular com base nas escápulas que tratavam-se de indivíduos com idade superior a seis meses (Sisson 1986).

No tocante à osteometria escapular, os machos apresentaram medidas em média superiores às das fêmeas (Quadro 5). Isto apoia-se na constatação de que os machos de $L$.

Quadro 5. Média aritmética $(\bar{x})$ e desvio padrão $(\sigma)$ das medidas obtidas nas escápulas de espécimes de Lycalopex gymnocercus adultos. Altura da escápula $(H S)$, altura diagonal da escápula $(D H A)$, menor comprimento no colo da escápula

(SLC), maior comprimento ao nível da tuberosidade supraglenoide (GLP), comprimento da cavidade glenoide $(L G)$ e largura da cavidade glenoide $(B G)$

\begin{tabular}{|c|c|c|c|c|c|c|c|}
\hline \multirow[t]{2}{*}{ Medidas } & \multicolumn{2}{|c|}{ Total $(n=16)$} & \multicolumn{2}{|c|}{ Fêmeas $(n=7)$} & \multicolumn{2}{|c|}{ Machos (n=9) } & \multirow{2}{*}{$\begin{array}{l}\text { Teste- } t \\
p \text {-valor }\end{array}$} \\
\hline & $\overline{\mathrm{x}}(\mathrm{mm})$ & $\sigma(\mathrm{mm})$ & $\overline{\mathrm{x}}(\mathrm{mm})$ & $\sigma(\mathrm{mm})$ & $\overline{\mathrm{x}}(\mathrm{mm})$ & $\sigma(\mathrm{mm})$ & \\
\hline HS & 87.99 & 4.51 & 86.45 & 3.45 & 89.0 & 5.02 & 0.30 \\
\hline DHA & 85.28 & 3.57 & 83.18 & 3.35 & 86.86 & 2.96 & 0.05 \\
\hline SLC & 15.95 & 1.00 & 15.94 & 1.40 & 15.96 & 0.71 & 0.97 \\
\hline GLP & 18.49 & 0.80 & 18.35 & 0.74 & 18.58 & 0.87 & 0.59 \\
\hline LG & 13.35 & 2.61 & 13.45 & 2.75 & 13.28 & 2.68 & 0.91 \\
\hline BG & 15.58 & 3.79 & 14.71 & 3.98 & 16.15 & 3.77 & 0.49 \\
\hline
\end{tabular}


gymnocercus têm porte maior do que as fêmeas (Queirolo et al. 2013).

A avaliação radiográfica da escápula isolada de um espécime macho de L. gymnocercus revelou o padrão trabecular concentrado no ângulo ventral do osso e sugeriu a formação de um canal vascular ao nível do colo (Fig.11). Áreas de radiopacidade aumentada predominaram nos contornos das margens e na extremidade lateral da espinha da escápula. A densidade óssea esteve claramente reduzida ao nível das fossas supra-infraespinhal e infra-espinhal e na espinha da escápula. Um espessamento radiodenso no extremo dorsal da espinha da escápula confirmou a formação de uma tuberosidade da espinha da escápula.

\section{Úmero (Estilopódio)}

O úmero, osso da região braquial, era composto por duas epífises e uma diáfise. A epífise proximal articulou-se com a escápula, formando a articulação escápulo-umeral (gleno-umeral); a distal com o rádio e a ulna, originando a articulação úmero-rádio-ulnar.

A cabeça do úmero (caput humeri) era ovalada com seu maior eixo no sentido crânio-caudal e mais pontiaguda cranialmente (Fig.12). Estendia-se craniodistalmente por alguns milímetros para formar o sulco intertubercular (sulcus intertubercularis), o qual separou os tubérculos ume-
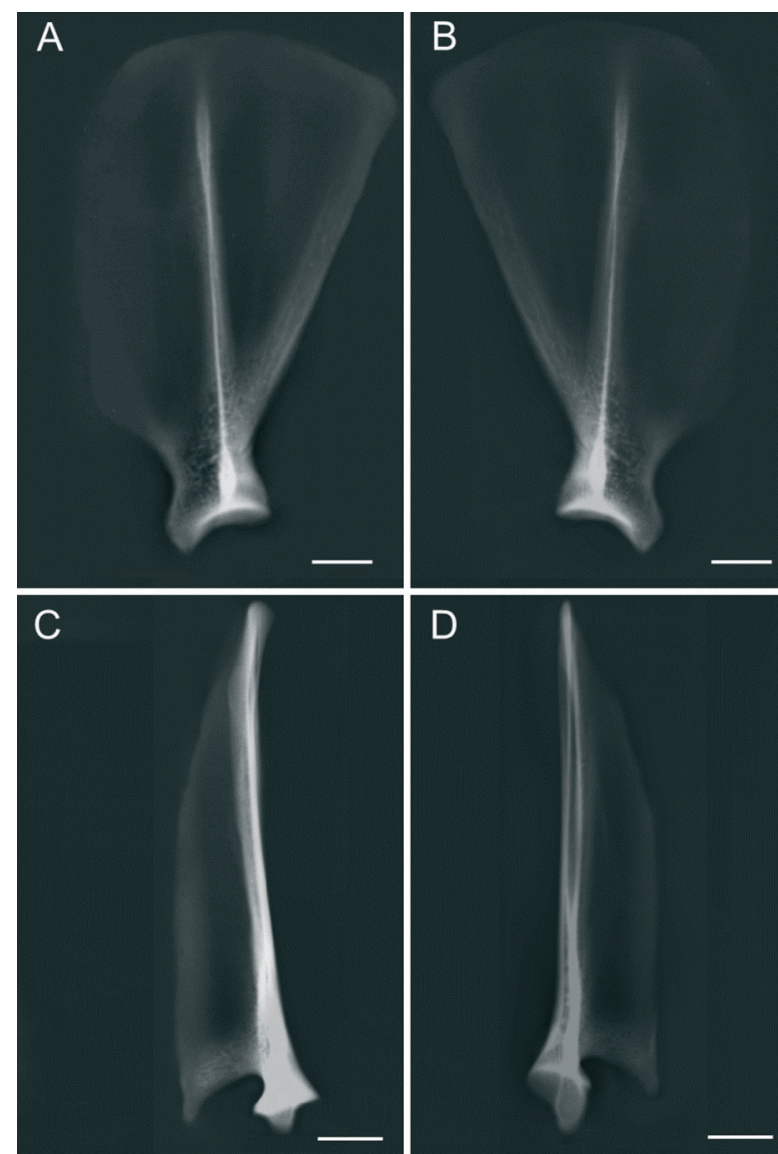

Fig.11. Radiografias da escápula esquerda de espécime macho, adulto, de Lycalopex gymnocercus (5274) nas projeções látero-medial (A), médio-lateral (B), caudo-cranial (C) e crânio-caudal (D), evidenciando padrão trabecular concentrado no ângulo ventral. Barra $=10 \mathrm{~mm}$.

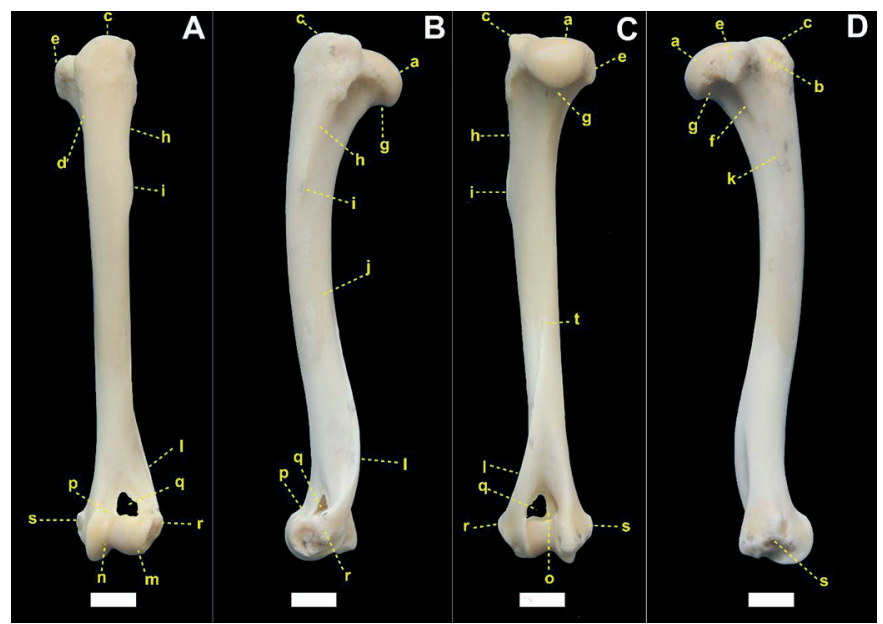

Fig.12. Fotomacrografias do úmero esquerdo de espécime macho de L. gymnocercus (8890) em vistas cranial (A), lateral (B), caudal (C) e medial (D), evidenciando a cabeça do úmero (a), sulco intertubercular (b), tubérculo maior (c), crista do tubérculo maior (d), tubérculo menor (e), crista do tubérculo menor (f), colo da cabeça do úmero (g), linha tricipital (h), tuberosidade deltoide (i), sulco para o músculo braquial (j), tuberosidade do músculo redondo maior (k), crista supracondilar lateral (1), capítulo (m), tróclea (n), fossa do olecrano (o), fossa radial (p), forame supratroclear (q), epicôndilo lateral (r), epicôndilo medial (s) e forame nutrício (t). Barra $=10 \mathrm{~mm}$.

rais. A cabeça do úmero em L. gymnocercus e C. l. familiaris demonstraram a extremidade caudal mais arredondada, enquanto em $C$. thous era sutilmente mais estreita (afilada).

Hildebrand (1954) verificou diferenças no contorno do topo da cabeça do úmero entre canídeos, sendo mais esféricas nos gêneros Chrysocyon e Lycalopex, mais achatadas nos gêneros Canis, Otocyon, Vulpes, Alopex e Fennecus e variável nos demais. Segundo Feeney (1999) foi mais esférica em $U$. cinereoargenteus e achatada em C. latrans e V.vulpes. Nos espécimes de L. gymnocercus do presente estudo a cabeça do úmero mostrou-se achatada e não esférica, como sugerido por Hildebrand (1954), à semelhança do encontrado em $C$. thous e C. l. familiaris examinados. Feeney (1999) considerou que o formato da cabeça do úmero conferia mais informações sobre o movimento do ombro do que a cavidade glenoide: quanto mais achatada, mais restrito é o movimento ao plano sagital (típico de cursoriais mais especializados); quanto mais esférica, maior a capacidade de adução e abdução.

0 tubérculo maior (tuberculum majus) foi a maior elevação proximal e cranial do osso nos espécimes de L. gymnocercus examinados. Isto foi uma característica também identificada por Feeney (1999) em outros três canídeos: $C$. latrans, $V$. vulpes e $U$. cinereoargenteus, porém neste último o tubérculo estende-se ainda mais cranialmente. A altura atingida por este arco do tubérculo maior variou discretamente entre indivíduos de $C$. thous. Em C. l. familiaris pode não ser o ponto mais proximal do osso, dependendo da raça (Evans \& DeLahunta 2013). Teve seu contorno proximal invariavelmente na forma de arco, dividido em uma parte cranial (maior) e outra caudal (menor) por um sulco raso, assim como relatado por Nickel et al. (1986) para cães.

$0 \mathrm{~m}$. supra-espinhal tem a função de estender a articulação gleno-umeral e, assim, atua como um sinergista na 
protração do úmero durante o galope. Portanto, quando o tubérculo maior tem localização mais proximal, como nos canídeos, ocorre um favorecimento mecânico para a ação do m. supra-espinhal. Isto é desejável para os cursoriais durante o deslocamento em maior velocidade (galope). Em contrapartida, em carnívoros que dificilmente galopam (ursídeos, procionídeos) o tubérculo maior não é tão proximal e o músculo atua principalmente na estabilização do ombro (Martín-Serra et al. 2014). Janis \& Figueirido (2014) acrescentaram que o tubérculo maior seria mais desenvolvido nos carnívoros que perseguem suas presas e menos naqueles que ficam à espreita.

Foram verificados vários pequenos forames entre o tubérculo maior e a superfície articular da cabeça do úmero; usualmente dois forames principais em L. gymnocercus e entre quatro a seis em $C$. thous. Na face lateral do tubérculo maior, próximo ao seu limite caudal, verificou-se a faceta para inserção do m. infra-espinhal. Esta foi mais destacada em C. thous, com formato claramente arredondado e menos nítida e mais alongada em L. gymnocercus. Na face cranial, o tubérculo prolonga-se distalmente formando a crista do tubérculo maior (crista tuberculi majoris), a qual mostrou-se mais discreta em L. gymnocercus e C. l. familiaris em comparação com $C$. thous.

0 tubérculo menor (tuberculum minus) foi visualizado na face medial, com aspecto nodular. Segundo Hildebrand (1954) o tubérculo menor de $C$. thous é o mais bem desenvolvido entre canídeos. De fato, seu tubérculo menor ultrapassou a altura da cabeça do úmero em C. thous e C. l. familiaris, mas em L. gymnocercus permaneceu praticamente no mesmo nível. A crista do tubérculo menor (crista tuberculi minoris) projeta-se distalmente a partir da face caudal do tubérculo e é bem desenvolvida em C. l. familiaris, especialmente nas raças grandes (Nickel et al., 1986), mas também o foi em L. gymnocercus e C. thous.

O sulco intertubercular de L. gymnocercus, C. thous e C. l. familiaris dispuseram-se orientados cranialmente, conforme notado por Feeney (1999) para os também canídeos $C$. latrans, $V$. vulpes e $U$. cinereoargenteus. Visto que este sulco é deslizado pelo tendão do m. bíceps braquial, sua orientação cranial restringe o direcionamento do músculo no plano sagital, limitando-o a realizar flexão do cotovelo. Esta adaptação seria típica de cursoriais especializados (Liem et al. 2013). Em espécies como a M. pennanti e o P. lotor, o sulco está posicionado medialmente em relação ao eixo longitudinal do membro, o que determina uma disposição para o $\mathrm{m}$. bíceps braquial capaz de atuar tanto na flexão do cotovelo como na supinação.

O colo do úmero (collum humeri) margeou distalmente a cabeça do úmero, comunicando as faces caudais dos tubérculos maior e menor. Sua superfície pode ser dividida na face caudal da diáfise por uma crista sagital mais evidente em L. gymnocercus e em C. thous e quase inaparente em C. l. familiaris. Nesta região originou-se a cabeça acessória do m. tríceps braquial e tal relevo foi descrito como menos evidente nos gêneros Nyctereutes e Speothos (Hildebrand 1954).

A diáfise (corpus humeri) umeral mostrou-se comprimida látero-medialmente na sua metade proximal e crânio-caudalmente na metade distal, conferindo aspecto levemente es- piralado ao osso, como em C. l. familiaris (Nickel et al. 1986). Apresentou quatro faces: lateral, medial, cranial e caudal.

$\mathrm{Na}$ face lateral (facies lateralis) encontrava-se a linha tricipital (linea m. tricipitis) a qual iniciava-se na junção entre a cabeça umeral com a extremidade caudal do tubérculo maior. Esta linha estendeu-se distalmente, em forma de arco convexo cranialmente, até o terço médio da diáfise e terminou na tuberosidade deltoide (tuberositas deltoides), conforme verificado nos canídeos $V$. vulpes, $C$. latrans e $U$. cinereoargenteus, no mustelídeo M. pennanti, no procionídeo P. lotor (Feeney 1999) e em C. l. familiaris (Evans \& DeLahunta 2013). Em M. pennanti e P. lotor estendeu-se a um nível mais distal na diáfise do úmero do que nos canídeos (Feeney 1999). Na sua parte mais proximal observou-se uma área rugosa para a inserção do m. redondo menor e o restante da linha servia para a origem da cabeça lateral do m. tríceps braquial. Em C. l. familiaris e C. thous, a linha foi contínua até se encerrar na tuberosidade deltoide. Em $L$. gymnocercus havia uma interrupção no terço médio da linha, o que a tornava inconspícua. 0 sulco para o $\mathrm{m}$. braquial (sulcus $m$. brachialis) ocupou a maior parte da face lateral da diáfise e conferiu aspecto retorcido ao osso.

A tuberosidade deltoide foi a projeção mais saliente da face lateral e serviu de inserção para as partes acromial e escapular do m. deltoide. De acordo com Nickel et al. (1986), nos cães de pequeno porte e gatos seria apenas uma área rugosa no terço proximal da diáfise, enquanto nos indivíduos de maior porte seria uma crista que se emenda com a linha tricipital. Esta última descrição pareceu a mais compatível com o encontrado em L. gymnocercus e C. thous. A parte rugosa (áspera) da tuberosidade fica voltada cranialmente em ambas espécies, assim como descrito para os também canídeos V. vulpes, C. latrans e U. cinereoargenteus (Feeney 1999).

Um dos poucos sinais de dimorfismo sexual relatado no esqueleto apendicular de canídeos refere-se à tuberosidade deltoide mais desenvolvida nos machos. Ruscillo (2002) especulou que o comportamento mais agressivo dos canídeos selvagens e domésticos machos, especialmente nas disputas pelo acasalamento, demandaria que os músculos que conectam o membro torácico ao pescoço e à cabeça sejam mais desenvolvidos. Alegou que na tuberosidade deltoide se fixaria a parte cleidobraquial do $\mathrm{m}$. braquiocefálico, o que cumpriria essa premissa. Entretanto, em $L$. gymnocercus o m. cleidobraquial se inseriu distalmente à tuberosidade deltoide. Visualmente a comparação entre os úmeros de espécimes machos e fêmeas de L. gymnocercus e C. thous não permitiu a observação de diferenças na forma ou tamanho da tuberosidade deltoide. Entretanto, o "teste da mesa"7 proposto por Ruscillo (2002), quando aplicado em sete úmeros de L. gymnocercus mostrou apenas $57 \%$ (4/7) de concordância quanto ao sexo.

\footnotetext{
0 "teste da mesa" descrito por Ruscillo (2002) consiste em posicionar a face cranial do úmero sobre uma mesa plana e soltá-lo. Se o osso se mantiver com a face cranial apoiada na mesa, provavelmente trata-se de um osso do sexo masculino; se o osso tombar para a face medial, o úmero seria de um espécime feminino. 0 autor menciona que o teste tem probabilidade de acerto em $85 \%$ dos machos de cães domésticos e $70 \%$ das fêmeas e 78\% em machos de $V$. vulpes. Também foi empregado em uma pequena amostragem de $C$. lupus com êxito.
} 
Na face medial (facies medialis) da diáfise verificou-se que a crista do tubérculo menor. Tal crista se prolongou distalmente e terminou caudalmente a um espessamento rugoso ao nível do terço proximal da diáfise, denominado tuberosidade redonda maior (tuberositas teres major). Enquanto em C. l. familiaris (Evans \& DeLahunta 2013) e em C. thous, esta tuberosidade encontrava-se no mesmo nível transversal da tuberosidade deltoide da face oposta, em $L$. gymnocercus posicionava-se um pouco mais proximal.

A face cranial (facies cranialis) continha proximalmente a crista do tubérculo maior, a qual se estendia distalmente até delimitar cranialmente o sulco para o $\mathrm{m}$. braquial. A face caudal (facies caudalis) se prolongava desde o colo do úmero até a crista supracondilar lateral (crista supracondylaris lateralis). Tanto em C. l. familiaris como nos espécimes de L. gymnocercus e $C$. thous o forame nutrício foi localizado na extremidade proximal da crista supracondilar lateral ao nível do terço médio da face caudal. Esta posição do forame nutrício também foi ilustrada em V. vulpes (Feeney 1999).

A epífise distal conteve a superfície articular para o rádio e a ulna, além de servir para a origem de treze músculos do antebraço. A superfície articular distal do úmero corresponde a um côndilo (condylus humeri) o qual foi dividido em duas partes: a lateral, menor, denominada capítulo ( $\mathrm{ca}$ pitulum humeri) que estabeleceu articulação com o rádio; a medial, maior, designada tróclea (trochlea humeri, pelo formato em "polia") em que predominou a articulação com a ulna. A tróclea umeral de L. gymnocercus era discretamente mais profunda do que a de $C$. thous, o que pode privilegiar movimentos no plano sagital, ideais para um cursorial especializado. A tróclea é citada como profunda nos gêneros cursoriais especializados Canis, Lycaon e Cuon e ampla em Speothos (Hildebrand 1954).

A depressão profunda encontrada na face caudal da epífise distal formou a fossa do olécrano (fossa olecrani), enquanto a depressão na face cranial originou a fossa radial (fossa radialis). Ambas profundas, garantem uma grande amplitude nos movimentos de extensão e flexão, desejável aos canídeos cursoriais. Em carnívoros menos velozes como M. pennanti e P. lotor foram descritas como rasas. 0 forame supratroclear (foramen supratrochleare) comunicou as fossas radial e do olécrano. 0 formato do forame variou entre diferentes espécimes de L. gymnocercus, C. thous e C. l. familiaris, porém no mesmo animal manteve-se com aparência semelhante entre antímeros. De fato, o formato e o tamanho da fossa do olécrano e do forame supratroclear não são características que permitem a distinção de espécies (Hildebrand 1954).

Fora do côndilo foram encontradas duas proeminências (epicôndilos): uma lateral (epicondylus lateralis) e outra medial (epicondylus medialis). À medida que o epicôndilo lateral se estendia proximalmente, afilava-se e tornava-se contínuo com a crista supracondilar lateral. Distalmente ao epicôndilo lateral e articulando-se lateralmente com a cabeça do rádio encontrou-se um osso sesamoide do $\mathrm{m}$. supinador (Fig.13) em todos os espécimes de L. gymnocercus examinados. Mais precisamente, o osso mediu entre 3 e $4 \mathrm{~mm}$ e se localizou no curso do tendão a alguns milímetros distal à sua origem. 0 grau de mineralização deste osso

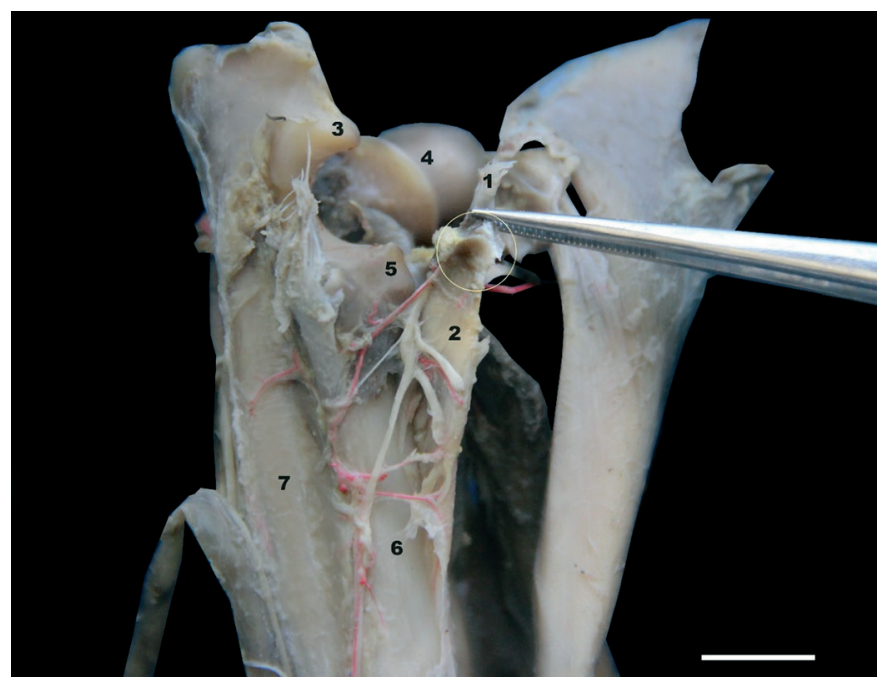

Fig.13. Fotomacrografia da região cubital direita de um espécime fêmea (8433), adulto, de Lycalopex gymnocercus em vista crânio-lateral evidenciando o tendão de origem do m. supinador livre de sua fixação no úmero (1), o ventre muscular do supinador (2), processo ancôneo (3), trócela umeral (4), cabeça do rádio (5), corpo do rádio (6), corpo da ulna (7) e o osso sesamoide do m. supinador (círculo). Barra =10mm.

era baixo pois não apareceu nas radiografias da articulação úmero-radio-ulnar e sua identificação só foi possível pela dissecção cuidadosa do tendão de origem do m. supinador. Em C. l. familiaris sua presença é considerada variável por Evans \& DeLahunta (2013).

0 epicôndilo medial mostrou-se mais proeminente que o lateral. Hildebrand (1954) referiu que o ponto de origem do $\mathrm{m}$. pronador redondo em relação às facetas para origem dos músculos flexores do carpo e dedos variam entre os canídeos. Segundo este autor, em Chrysocyon brachurus os pontos de origem estariam no mesmo plano transversal, enquanto em Speothos a origem do pronador seria imeditamente proximal e no gênero Canis estaria em uma posição intermediária. Em L. gymnocercus e $C$. thous a disposição do ponto de origem do $\mathrm{m}$. pronador redondo em relação aos dos flexores do carpo e dedos assemelhou-se ao do gênero Canis.

Ainda que um forame supracondilar (entepicondilar) para a passagem do nervo mediano e da artéria braquial seja descrito para a maioria dos carnívoros (Hildebrand 1954), inclusive felinos domésticos (ICVGAN 2012), não foi encontrado em L. gymnocercus nem em $C$. thous. Também não foi observado por Feeney (1999) em $V$. vulpes, $C$. latrans nem $U$. cinereoargenteus. Isto já era esperado pois tal forame costuma estar ausente em canídeos, ursídeos e mustelídeos (Hildebrand 1954), ainda que Feeney (1999) descrevesse-o como presente no mustelídeo M. pennanti. De acordo com Wang (1993) o forame supracondilar aparece presente na maior parte dos canídeos primitivos e foi perdido nos mais recentes, o que determinou, inclusive, um epicôndilo medial menos desenvolvido. Já Martín-Serra et al. (2014) sugerem que um epicôndilo medial mais desenvolvido seria necessário para uma vantagem mecânica para os músculos pronadores e flexores do carpo e dedos, movimento menos necessário aos canídeos do que a outras famílias. Assim, a presença de um forame supratroclear e a 
ausência do forame supracondilar distinguiria o úmero dos canídeos atuais dos demais carnívoros (Hildebrand 1954).

Embora diferenças tenham sido encontradas nos acidentes anatômicos e formas do úmero entre L. gymnocercus, C. thous e C. l. familiaris, as mesmas são sutis. Pode ser inferido visualmente que o úmero de L. gymnocercus é mais delgado e o de $C$. thous mais robusto. De fato, isto foi confirmado pelo índice de robustez umeral (URI) médio de L. gymnocercus ser 0,065 e de C. thous 0,072 (Quadro 6). Dentre os índices morfológicos propostos por Samuels et

Quadro 6. Resultados dos índices morfológicos em um espécime de Cerdocyon thous e da média dos índices de dezesseis espécimes de Lycalopex gymnocercus. As colunas "Terrestre" e "Cursorial" representam as médias nas espécies carnívoras examinadas por Samuels et al. (2013)

\begin{tabular}{ccccc}
\hline Índice & $\begin{array}{c}\text { C. thous } \\
(\mathrm{n}=1)\end{array}$ & $\begin{array}{c}\text { L. gymnocercus } \\
(\mathrm{n}=16)\end{array}$ & Terrestre $^{\mathrm{a}}$ & Cursorial $^{\mathrm{b}}$ \\
\hline SMI & 0,400 & 0,395 & 0,469 & 0,424 \\
BI & 0,922 & 0,935 & 0,870 & 1,005 \\
HRI & 0,072 & 0,065 & 0,077 & 0,070 \\
HEI & 0,201 & 0,173 & 0,226 & 0,187 \\
OLI & 0,103 & 0,116 & 0,160 & 0,139 \\
URI & 0,057 & 0,049 & 0,053 & 0,042 \\
MANUS & nd & 0,348 & 0,475 & 0,408
\end{tabular}

a Segundo Samuels et al. (2013) "Terrestres" são as espécies que ficam maior parte do tempo no solo, porém raramente podem nadar, escalar ou escavar, " "Cursoriais" seria a classificação das espécies que regularmente dispõem de locomoção rápida com momentos de ausência de apoio no solo, nd: não disponível.

al. (2013) foi o único que variou entre as duas espécies. A partir disto pode-se sugerir que $C$. thous tenha menos velocidade, enquanto L. gymnocercus seja mais ágil, talvez para cumprir uma provável predileção carnívora em comparação com o primeiro (Queirolo et al., 2013). Por outro lado, estas diferenças sutis corroboram Hildebrand (1954) que concluiu que o úmero isoladamente permite a identificação de poucos gêneros de canídeos, a exceção dos úmeros de $C$. brachyurus e Speothos venaticus, os quais têm formatos bem peculiares. $S$. venaticus inclusive é o canídeo com maior espessura cortical no úmero, talvez decorrente de usar os membros torácicos também para nadar, escavar e capturar presas maiores (Meachen-Samuels 2010).

A largura da epífise distal (Bd) no úmero dos espécimes machos foi significativamente maior $(\mathrm{p}=0,03)$ (Quadro 7).

Quadro 7. Média aritmética $(\bar{x})$ e desvio padrão $(\sigma)$ das medidas obtidas nos úmeros espécimes de Lycalopex gymnocercus adultos. Comprimento total do úmero $(G L)$, comprimento desde a cabeça do úmero $(G L C)$, comprimento crânio-caudal da epífise proximal $(D p)$, menor largura do meio da diáfise $(S D)$, largura da extremidade distal $(B d)$, comprimento da crista do tubérculo maior $(D P C L), \mathrm{p}<0.05\left(^{*}\right)$

\begin{tabular}{|c|c|c|c|c|c|c|c|}
\hline \multirow[t]{2}{*}{ Medidas } & \multicolumn{2}{|c|}{ Geral (n=16) } & \multicolumn{2}{|c|}{ Fêmeas (n=7) } & \multicolumn{2}{|c|}{ Machos (n=9) } & \multirow{2}{*}{$\begin{array}{l}\text { Teste-t } \\
\text { p-valor }\end{array}$} \\
\hline & $\overline{\mathrm{x}}(\mathrm{mm})$ & $\sigma(\mathrm{mm})$ & $\overline{\mathrm{x}}(\mathrm{mm})$ & $\sigma(\mathrm{mm})$ & $\overline{\mathrm{x}}(\mathrm{mm})$ & $\sigma(\mathrm{mm})$ & \\
\hline GL & 121,52 & 4,95 & 121,02 & 4,77 & 121,90 & 5,33 & 0,74 \\
\hline GLC & 120,10 & 5,02 & 119,36 & 4,84 & 120,68 & 5,36 & 0,62 \\
\hline $\mathrm{Dp}$ & 26,19 & 1,16 & 25,76 & 1,34 & 26,52 & 0,95 & 0,21 \\
\hline SD & 7,92 & 0,47 & 7,93 & 0,31 & 7,91 & 0,58 & 0,93 \\
\hline $\mathrm{Bd}$ & 21,03 & 1,31 & 20,26 & 0,78 & 21,64 & 1,35 & $0,03 *$ \\
\hline DPCL & 48,08 & 4,06 & 46,34 & 4,07 & 49,44 & 3,72 & 0,1 \\
\hline
\end{tabular}

Isto decorre de epicôndilos umerais maiores nos machos, o que permitiria a fixação de músculos extensores e flexores do carpo e dedos funcionalmente mais fortes para a captura da presa e aceleração durante o galope.

A partir das análises tridimensionais, estimou-se a área da cabeça do úmero como $341,9 \mathrm{~mm}^{2}$, enquanto a cavidade glenoide da escápula possuía $129,61 \mathrm{~mm}^{2}$. Portanto, a superfície articular da cabeça do úmero é mais que o dobro (2,6 vezes) da superfície da cavidade glenoide, o que possibilita maior amplitude de movimentos da articulação escápulo-umeral, ainda que limitados pelos músculos, tendões e ligamentos. Esta constatação está de acordo com o relatado para o cão, em que a superfície articular da cabeça umeral seria aproximadamente o dobro do tamanho da cavidade glenoide (Evans \& DeLahunta 2013). Ainda foi possível determinar que os côndilos umerais possuem área total de $281,19 \mathrm{~mm}^{2}$ e o úmero como um todo $5564,32 \mathrm{~mm}^{2}$. Portanto, a cabeça do úmero constituiu 6,1\% da superfície umeral, enquanto os côndilos $5,1 \%$.

As radiografias do úmero isoladamente (Fig.14) permitiram visualizar a espessura cortical maior na diáfise e
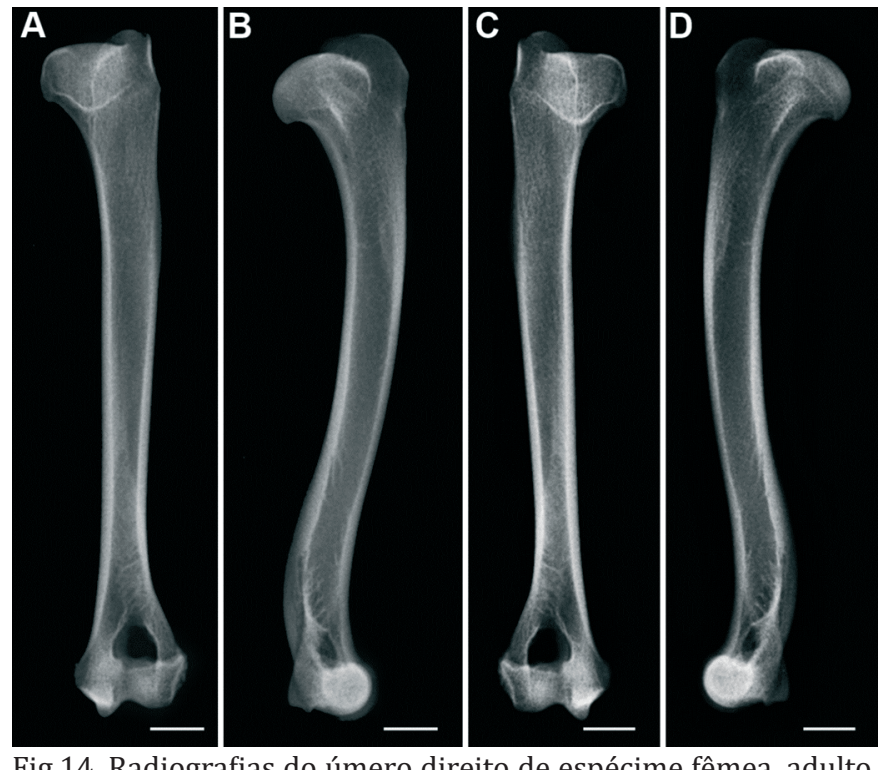

Fig.14. Radiografias do úmero direito de espécime fêmea, adulto, de Lycalopex gymnocercus nas projeções caudo-cranial (A), látero-medial (B), crânio-caudal (C), médio-lateral (D) as características de trabeculação e contorno umeral. Barra $=10 \mathrm{~mm}$.

menor nas epífises. A tuberosidade deltoide apareceu nas projeções látero-medial e médio-lateral como uma área radiodensa destacada, decorrente da rigidez necessária nesta área para a inserção das duas partes do m. deltoide. A trabeculação foi mais radiopaca na região distal, proximalmente às fossas radial e do olecrano. Na radiografia da região braquial de um espécime adulto jovem (Fig.15), ficou nítido o formato de cunha assumido pelo disco epifisário cartilagíneo proximal do úmero.

A localização dos principais acidentes anatômicos do úmero em um sistema de coordenadas tridimensional encontra-se no Quadro 8. 

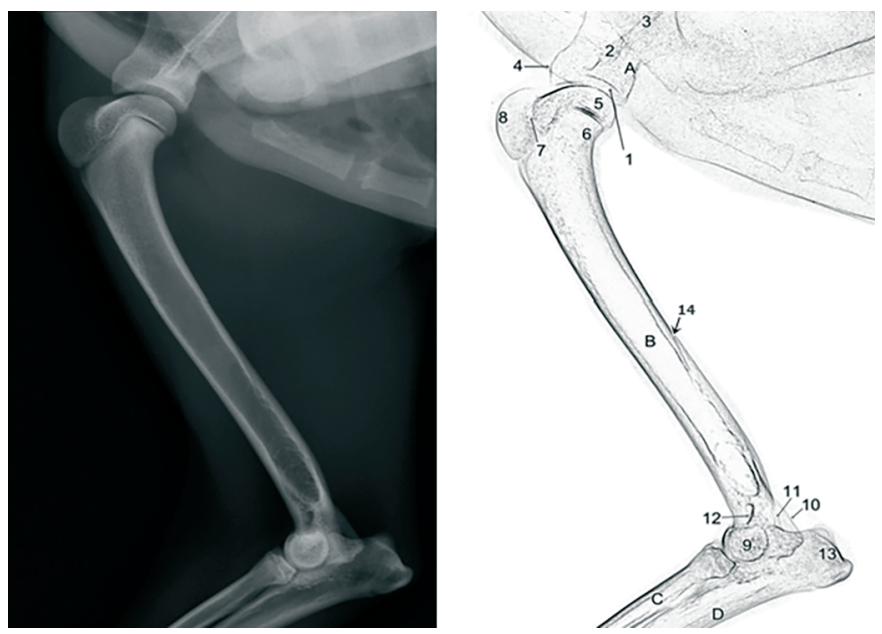

Fig.15. Radiografia (à esquerda) e representação esquemática (à direita) da região braquial direita de espécime macho de $L y$ calopex gymnocercus em projeção mediolateral revelando os ossos Escápula(A), Úmero (B), Rádio (C) e Ulna (D) e os acidentes anatômicos cavidade glenoide (1), acrômio (2), espinha da escápula (3), tubérculo supraglenoide (4), cabeça do úmero (5), colo da cabeça do úmero (6), sulco intertubercular (7), tubérculo maior (8), côndilo umeral (9), epicôndilo medial (10), epicôndilo lateral (11), forame supratroclear (12), tuberosidade do olecrano (13) e forame nutrício (14). Barra = $10 \mathrm{~mm}$.

Quadro 8. Localização dos principais acidentes anatômicos do úmero de um espécime fêmea, adulto, de Lycalopex gymnocercus em sistema de eixo de coordenadas

\begin{tabular}{lccc}
\hline Acidente anatômico & $\begin{array}{c}\text { Eixo X } \\
(\mathrm{mm})\end{array}$ & $\begin{array}{c}\text { Eixo Y } \\
(\mathrm{mm})\end{array}$ & $\begin{array}{c}\text { Eixo Z } \\
(\mathrm{mm})\end{array}$ \\
\hline Tubérculo menor & $-0,95$ & $-2,76$ & 112,13 \\
Sulco intertubercular & 5,98 & $-0,72$ & 110,49 \\
Tubérculo maior & 10,32 & 0,31 & 115,25 \\
Tuberosidade deltoide & 14,78 & 4,23 & 78,44 \\
Extremidade caudal da cabeça do úmero & 1,22 & $-15,44$ & 99,76 \\
Extremidade caudal do tubérculo maior & 13,67 & $-9,67$ & 110,32 \\
Extremidade cranial do tubérculo maior & 4,84 & 5,66 & 109,35 \\
Epicôndilo medial & $-10,62$ & 0 & 0 \\
Epicôndilo lateral & 10,62 & 0 & 0 \\
Forame nutrício & $-0,40$ & $-4,63$ & 34,81 \\
Extremidade distal do forame supratroclear & 1,24 & $-1,47$ & 1,06 \\
Extremidade caudal do tubérculo menor & $-6,02$ & $-5,77$ & 103,67 \\
Extremidade cranial do tubérculo menor & $-1,00$ & $-0,63$ & 107,20
\end{tabular}

\section{Rádio e Ulna (Zeugopódio)}

0 rádio foi um osso mais curto que a ulna e bem menos acidentado para a fixação de músculos. Os dois ossos juntos formaram a região antebraquial. 0 comprimento do rádio contribuiu para $27,0 \%$ do comprimento total médio do esqueleto do membro torácico de L. gymnocercus. 0 rádio de L. gymncoercus possuiu um achatamento crânio-caudal e uma convexidade cranial conforme descrito para C. l. familiaris por Nickel et al. (1986) e Sisson (1986). O rádio articulou-se proximalmente com o úmero (articulação úmero-radial) e ulna (articulação rádio-ulnar) para formar a articulação úmero-rádio-ulnar (cotovelo). A sua região distal conectou-se lateralmente com a ulna (articulação rádio-ulnar) e distalmente com os ossos do carpo (articulação radio-carpiana) como parte da articulação antebraquiocarpiana.

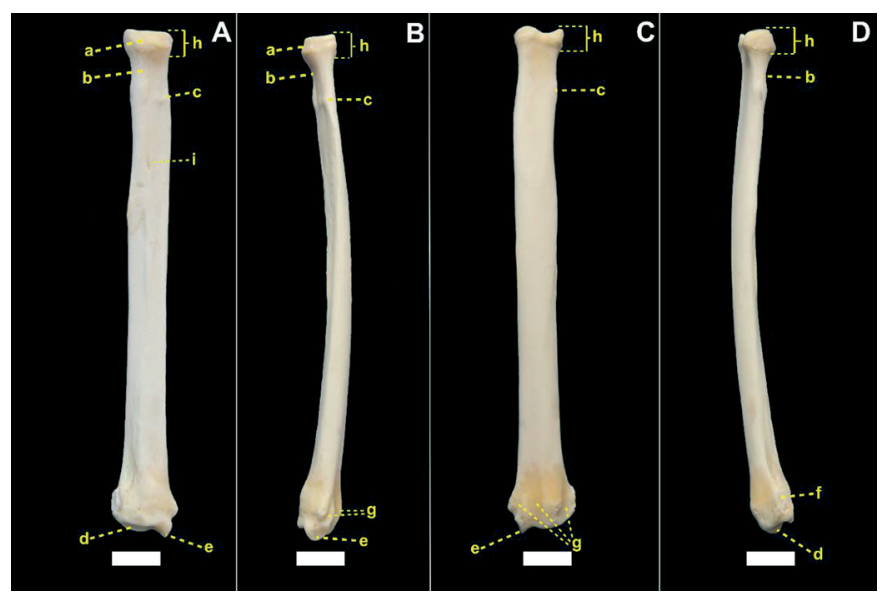

Fig.16. Fotomacrografia do rádio esquerdo de espécime macho de Lycalopex gymnocercus em vistas caudal (A), medial (B), cranial (C) e lateral (D), evidenciando a circunferência articular (a), colo do rádio (b), tuberosidade radial (c), face articular para o carpo (d), processo estiloide medial (e), incisura ulnar (f), sulcos extensores (g), cabeça do rádio (h) e forame nutrício (i). Barra $=10 \mathrm{~mm}$.

A extremidade proximal apresentou uma cabeça (caput radii) e um colo (collum radii) (Fig.16). 0 contorno caudal da cabeça foi convexo e formou uma circunferência articular (circumferentia articularis) que se encaixava na incisura radial da ulna. A superfície articular desta circunferência tinha o comprimento cerca de um terço maior do que a incisura radial com a qual se articulava, deixando margem para uma rotação do rádio sobre a ulna, necessária para os movimentos de pronação e supinação. A superfície articular da cabeça demonstrou uma concavidade, a fóvea articular (fovea capitis radii), a qual se articulou com o capítulo umeral e parte lateral da tróclea umeral, suportando a maior parcela do impacto do braço sobre o antebraço durante a fase de apoio da passada.

A largura médio-lateral da cabeça do rádio é uma medida associada com a identificação dos gêneros de canídeos como também com o tipo de habitat que a espécie se distribui (Meloro \& Louys 2015). No caso de L. gymnocercus mediu $11,49 \pm 0,56 \mathrm{~mm}$, sem diferença significativa entre os sexos (Quadro 9).

Apoiando a cabeça do rádio esteve o colo, uma região estreitada. Distal e medialmente ao colo, existia uma tuberosidade radial (tuberositas radii) a qual estendia-se desde a margem medial à face caudal da diáfise em posicionamento relativamente constante entre os espécimes de $L$. gymnocercus e C. thous. Em C. l. familiaris o posicionamento

Quadro 9. Média aritmética $(\bar{x})$ e desvio padrão $(\sigma)$ das medidas obtidas nos rádios dos espécimes de Lycalopex gymnocercus adultos. Comprimento total do rádio ( $G L)$, Largura na epífise proximal $(B p)$, menor largura do meio da diáfise $(S D)$, largura da extremidade distal $(B d)$

\begin{tabular}{|c|c|c|c|c|c|c|c|}
\hline \multirow[t]{2}{*}{ Medidas } & \multicolumn{2}{|c|}{ Geral $(n=16)$} & \multicolumn{2}{|c|}{ Fêmeas $(n=7)$} & \multicolumn{2}{|c|}{ Machos $(n=9)$} & \multirow{2}{*}{$\begin{array}{l}\text { Teste-t } \\
\text { p-valor }\end{array}$} \\
\hline & $\overline{\bar{x}}(\mathrm{~mm})$ & $\sigma(\mathrm{mm})$ & $\overline{\bar{x}}(\mathrm{~mm})$ & $\sigma(\mathrm{mm})$ & $\overline{\mathrm{x}}(\mathrm{mm})$ & $\sigma(\mathrm{mm})$ & \\
\hline GL & 113,63 & 4,45 & 116,32 & 4,26 & 115,14 & 4,41 & 0,24 \\
\hline $\mathrm{Bp}$ & 11,49 & 0,56 & 11,76 & 0,69 & 11,64 & 0,63 & 0,42 \\
\hline SD & 8,00 & 0,77 & 8,16 & 0,78 & 8,09 & 0,75 & 0,70 \\
\hline $\mathrm{Bd}$ & 14,02 & 2,14 & 13,98 & 1,74 & 14,00 & 1,86 & 0,97 \\
\hline
\end{tabular}


da tuberosidade radial varia bastante entre raças (Evans \& DeLahunta 2013).

O corpo do rádio era achatado crânio-caudalmente, especialmente na região proximal. Na face cranial (facies cranialis) encontrava-se uma área áspera para a inserção do m. supinador. Tal inserção do m. supinador se deu em nível ligeiramente mais proximal do que a do m. pronador redondo, tanto em C. l. familiaris (Evans \& DeLahunta 2013) como em L. gymnocercus, C. thous e Procyon cancrivorus (Silva et al. 2015). A face caudal (facies caudalis) era côncava e possuía uma linha vertical que alcançava a epífise distal em L. gymnocercus, mas não em C. l. familiaris (Evans \& DeLahunta 2013) nem em $C$. thous. Esta linha dividia a face caudal em duas superfícies: uma medial mais larga (2/3) e outra lateral mais curta (1/3). Uma elevação rugosa se localizava no terço proximal da face caudal e se direcionava para a margem lateral do osso. Tal elevação era bem suave no L. gymnocercus e mais proeminente em C. l. familiaris e $C$. thous. Como esta elevação servia para o ligamento interósseo, pode ser que a união entre rádio e ulna em $L$. gymnocercus seja um pouco mais frouxa e permita algum movimento adicional de rotação. No terço proximal da face caudal encontrava-se um forame nutrício, medialmente à esta elevação para o ligamento interósseo. A face caudal do rádio era mais robusta e convexa a medida que se aproximava da tróclea. Esta convexidade era mais pronunciada de L. gymnocercus do que em C. thous e C. l. familiaris.

Na margem medial da diáfise localizou-se uma linha para a inserção do m. pronador redondo, a qual fora mais desenvolvida em C. l. familiaris e menos em L. gymnocercus e ainda mais discreta em $C$. thous.

A extremidade distal do rádio, tróclea (trochlear radii), possuía uma superfície articular principal para a fileira proximal do carpo (facies articularis carpea), especialmente para o osso intermédio-radial. Esta superfície era côncava e delimitada medialmente pelo processo estiloide (processus styloideus), com uma tuberosidade proximalmente, e lateralmente pela incisura ulnar (incisura ulnaris). 0 processo estiloide é ligeiramente mais pontiagudo em L. gymnocercus e $C$. thous do que em $C$. l. familiaris em conformidade com Hildebrand (1954) que afirma ser mais pontiagudo nos gêneros Lycalopex, Cerdocyon, Nyctereutes e Speothos, assemelhando-se ao de felinos. A área achatada para origem do ligamento cárpico medial era um pouco mais ampla e sulcada em C. l. familiaris, sulcada em $C$. thous e praticamente lisa em L. gymnocercus. Isto pode sugerir um ligamento mais forte em $C$. l. familiaris e que comparativamente o carpo dos canídeos silvestres teria mais mobilidade nesta região.

A face cranial da tróclea radial apresentou três sulcos extensores: o mais lateral para o tendão do $\mathrm{m}$. extensor comum dos dedos; o intermédio (mais profundo) para o tendão do m. extensor radial do carpo; e o mais medial e estreito para o tendão do $\mathrm{m}$. abdutor longo do primeiro dedo cruzar obliquamente sobre a face cranial do rádio e se inserir no primeiro metacarpiano. Comparativamente a separação entre os sulcos lateral e médio é mais pronunciada em L. gymnocercus. Segundo Meloro \& Louys (2015), a profundidade do sulco para o m. extensor radial do carpo é a característica na região distal do rádio que melhor permite diferenciar gêneros de canídeos e está altamente correlacionada com a preferência por habitat da espécie. Entretanto estas diferenças não foram visualmente aparentes entre os espécimes disponíveis deste estudo. Talvez esse grau de detalhamento possa ser obtido por análises mais apuradas de morfometria geométrica.

A face caudal da tróclea era repleta de forames e possuía um tubérculo, o qual era mais robusto em L. gymnocercus do que em $C$. l. familiaris e $C$. thous. Não existia uma crista transversa, diferente do reconhecido para felinos e outros mamíferos (Nickel et al. 1986).

A ulna (Fig.17) formou a base óssea caudal do antebraço e também foi o osso mais longo do membro torácico de L. gymnocercus (Quadro 10). Articulou-se proximalmente

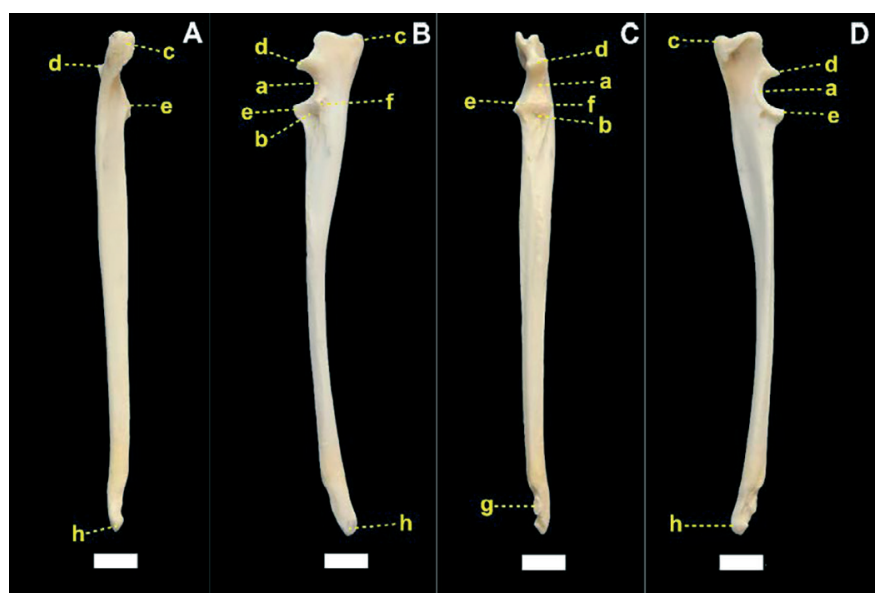

Fig.17. Fotomacrografia da ulna esquerda de espécime macho de Lycalopex. gymnocercus em vistas caudal (A), lateral (B), cranial (C) e medial (D), evidenciando a incisura troclear (a), face para a circunferência articular do rádio (b), tuberosidade do olecrano (c), processo ancôneo (d), processo coronoide medial (e), processo coronoide lateral (f), circunferência articular (g), processo estiloide (h). Barra $=10 \mathrm{~mm}$.

com o úmero pela incisura troclear (incisura trochlearis) e com o rádio pela incisura radial (incisura radialis). Sua extremidade distal (cabeça) articulou-se com a incisura ulnar do rádio e com os ossos carpianos ulnar e acessório.

A extremidade proximal da ulna foi formada predominantemente pelo olecrano (olecranon). Este compreendeu

Quadro 10. Média aritmética $(\bar{x})$ e desvio padrão $(\sigma)$ das medidas obtidas nas ulnas dos espécimes de Lycalopex gymnocercus adultos. Comprimento total da ulna $(G L)$, profundidade desde o processo anconeo (DPA), menor profundidade do olecrano ( $S D O)$, largura entre os processos coronoides (BPC), comprimento funcional da ulna (FUL), comprimento do olecrano $(U L O L)$ e largura no meio da diáfise $(U D)$

\begin{tabular}{|c|c|c|c|c|c|c|c|}
\hline \multirow[t]{2}{*}{ Medidas } & \multicolumn{2}{|c|}{ Geral $(n=16)$} & \multicolumn{2}{|c|}{ Fêmeas (n=7) } & \multicolumn{2}{|c|}{ Machos (n=9) } & \multirow{2}{*}{$\begin{array}{l}\text { Teste-t } \\
\text { p-valor }\end{array}$} \\
\hline & $\overline{\bar{x}}(\mathrm{~mm})$ & $\sigma(\mathrm{mm})$ & $\overline{\bar{x}}(\mathrm{~mm})$ & $\sigma(\mathrm{mm})$ & $\overline{\mathrm{x}}(\mathrm{mm})$ & $\sigma(\mathrm{mm})$ & \\
\hline GL & 134,18 & 5,28 & 132,69 & 5,55 & 135,49 & 5,01 & 0,32 \\
\hline & & & & & & & 37 \\
\hline & & & & & & & 13 \\
\hline & & & & & & & 0,29 \\
\hline & & & & & & 7 & 0,26 \\
\hline ULO & & 1,2 & 14,10 & 1,0 & 14,42 & 1,3 & 0,61 \\
\hline UD & 6,09 & 0,70 & 6,08 & 0,50 & 6,10 & 0,85 & 0,96 \\
\hline
\end{tabular}


a tuberosidade do olecrano (tuber olecrani) e o processo ancôneo (processus anconeus). No olecrano fixaram-se os músculos extensores do cotovelo, em especial as inserções das cabeças tricipitais. Seu formato era medialmente côncavo e lateralmente convexo, tendo sua extremidade proximal inclinada medialmente quando vista caudalmente. Segundo Hildebrand (1954) essa curvatura é mais proeminente nos canídeos dos gêneros Nyctereutes e Cerdocyon. Na comparação entre L. gymnocercus e C. thous não foi possível notar diferença nesta inclinação.

A região caudal da extremidade proximal do olecrano era arredondada, enquanto a parte cranial era sulcada. 0 sulco era delimitado por elevações medial e lateral. Tanto em espécimes de L. gymnocercus como de $C$. thous a elevação medial surgia mais comprida no sentido crânio-caudal e mais alta proximalmente na maioria dos casos, embora em poucos espécimes esta diferença não fosse tão nítida. Não foi possível correlacionar a altura desta elevação com dimorfismo sexual. Tais elevações foram denominadas tubérculos medial e lateral e seriam pouco desenvolvidas no gênero Speothos (Hildebrand 1954, Salesa et al. 2010). 0 tubérculo medial mais elevado é uma característica relatada para canídeos enquanto o lateral mais proeminente ou do mesmo tamanho seria mais frequente em felídeos (a exceção do Acinonyx jubatus) (Salesa et al. 2010). Pode-se sugerir que nas espécies que possuem o tubérculo medial mais elevado a cabeça medial do m. tríceps braquial seja mais curta, como no caso de A. jubatus e outros felídeos extintos (Salesa et al. 2010).

A incisura troclear era uma superfície articular com o formato de "meia-lua". Sua concavidade voltava-se cranialmente. Possuía uma crista sagital que permitia o encaixe da tróclea umeral e que restringiria os movimentos ao plano sagital. Proximalmente terminava em uma ponta, denominada processo ancôneo, a qual se projetava na fossa do olecrano do úmero, constituindo uma adaptação importante para a estabilidade do cotovelo. A superfície articular da incisura troclear era mais ampla na face lateral do processo ancôneo, mais nitidamente em L. gymnocercus e C. thous do que no cão. Talvez isto possibilite um movimento de abdução um pouco mais amplo. Contudo, Hildebrand (1954) afirmou que o processo ancôneo não possui diferenças importantes entre as espécies de canídeos.

Distalmente à incisura troclear formaram-se dois processos coronoides, um medial e outro lateral. 0 processo coronoide medial (processus coronoideus medialis) era mais largo para suportar a maior parte da tróclea umeral. 0 processo coronoide lateral (processus coronoideus lateralis), mais curto, articulava-se com a parte lateral da tróclea e capítulo. Um processo coronoide medial mais desenvolvido que o lateral é uma característica de carnívoros (Sisson, 1986). Por meio da osteometria tridimensional na ulna de um espécime fêmea de L. gymnocercus, pode-se inferir que o processo coronoide medial tinha $50 \%$ a mais de superfície articular do que o processo lateral. A extremidade do processo coronoide medial atingiu um nível mais distal do que a do processo lateral. 0 intervalo entre as extremidades dos processos coronoides formara o limite proximal da incisura radial para se ajustar à circunferência articular do rádio. Na face cranial do osso, dos dois processos surgiram duas cristas que seguiam trajeto distal e convergentes. Juntamente com a incisura radial delimitaram um triângulo, tal qual em C. l. familiaris (Evans \& DeLahunta 2013).

O corpo da ulna (corpus ulnae) possuía três faces (facies lateralis, facies medialis e facies cranialis) e quatro margens (margo lateralis, margo medialis, margo caudalis e margo interosseus). Era mais largo crânio-caudalmente na região proximal e mais fino e arredondado na parte distal. A face cranial possuía uma área rugosa para a fixação do ligamento interósseo, o qual juntava a ulna ao rádio. Esta área foi comparativamente mais larga e curta em C. l. familiaris e alongada e comprida em L. gymnocercus e C. thous. Proximalmente a esta área, encontrava-se o forame nutrício nas três espécies. A margem interóssea, característica de carnívoros (ICVGAN 2012), foi mais destacada em C. l. familiaris do que em L. gymnocercus e C. thous. Medialmente à esta margem, observou-se um sulco para a artéria interóssea
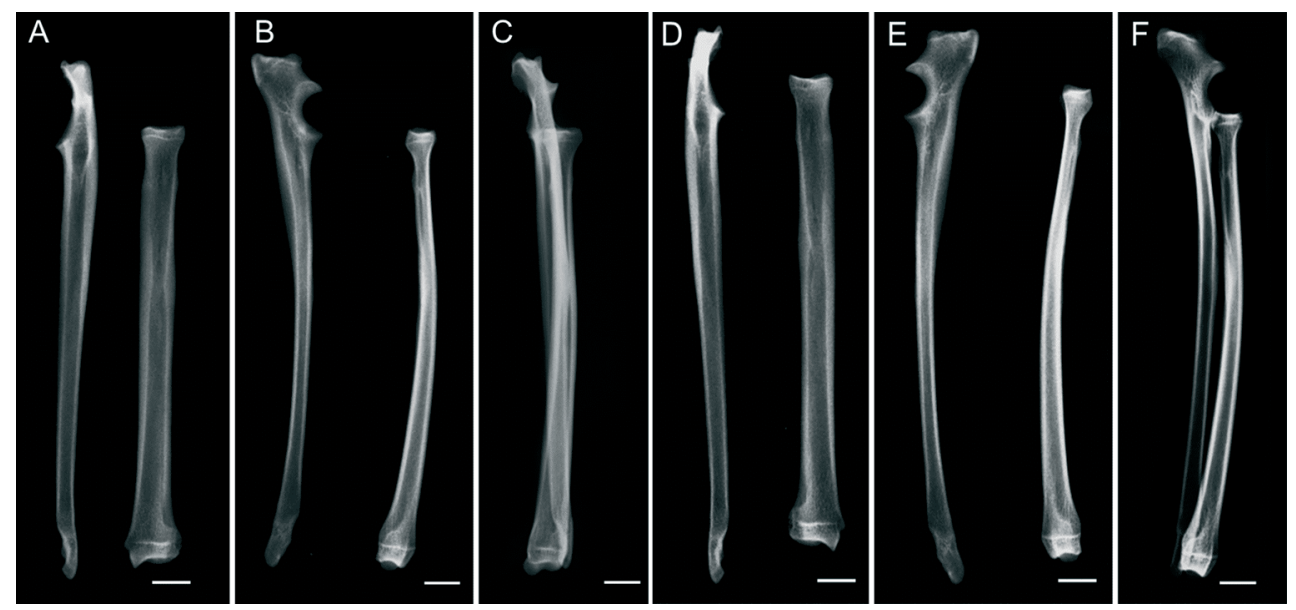

Fig.18. Radiografias do rádio e ulna direitos separados de espécime fêmea, adulto, de Lycalopex gymnocercus e articulados de espécime macho, adulto nas projeções caudo-cranial (A), látero-medial (B), crânio-caudal articulados (C), crânio-caudal (D), médio-lateral (E) e látero-medial articulados (F). 0 rádio apresenta contorno convexo cranialmente com camada cortical mais espessa na metade diafisária proximal, o que determina uma cavidade medular mais estreita nesta região. A ulna destes espécimes apresentou olecrano inclinado medialmente com tubérculo medial mais alto. A trabeculação ulnar foi mais densa na região proximal como reflexo da inserção de músculos mais fortes naquela região. Barra $=10 \mathrm{~mm}$. 
caudal, que se estendia entre os terços médio e distal do corpo da ulna.

A margem caudal tratava-se de uma elevação fina que atingiu sua maior concavidade no terço médio. Era inclinada medialmente e mais robusta à medida que atingia a região proximal na zona de transição com o olecrano. A margem medial iniciou distalmente à ponta do processo coronoide medial e se prolongou até o terço distal do corpo do osso. A margem lateral surgiu distalmente ao processo coronoide lateral e se estendeu até o mesmo nível da medial. Ambas as margens foram suaves em L. gymnocercus e C. thous se comparadas a C. l. familiaris.

A extremidade distal da ulna formou a cabeça da ulna (caput ulnae), assim denominada pelo seu formato arredondado. Destacou-se do corpo da ulna por uma incisura localizada proximalmente à uma superfície articular arredondada e levemente voltada proximalmente, a circunferência articular (circumferentia articularis). Esta circunferência apôs-se à incisura ulnar do rádio. A projeção mais distal e romba constituiu o processo estiloide (processus styloideus). Assim, como em C. l. familiaris (Evans \& DeLahunta 2013), este processo exibia duas facetas para articulação com os ossos carpianos ulnar e acessório.

As radiografias dos ossos rádio e ulna separados ou articulados (Fig.18 e 19) revelaram que o disco epifisário cartilagíneo proximal do rádio teve formato sinuoso que acompanhava, de certa forma, o contorno do côndilo umeral. 0 disco epifisário distal demonstrou formato transverso. As corticais do rádio eram bem próximas na metade proximal da diáfise, o que tornou a cavidade medular estreita. Esta peculiaridade foi decorrente do achatamento crânio-caudal do osso e pode representar uma dificuldade adicional para a colocação de implantes em osteossínteses.

A ulna apresentou trabeculação mais marcada na região do olecrano, viso que esta área que demanda maior rigidez para suportar as alavancas dos músculos extensores do cotovelo bem como o impacto no cotovelo. A conformação da congruência articular úmero-radio-ulnar (Fig.20 e 21) foi semelhante à ilustrada por Schebitz \& WIlkens (1987) para
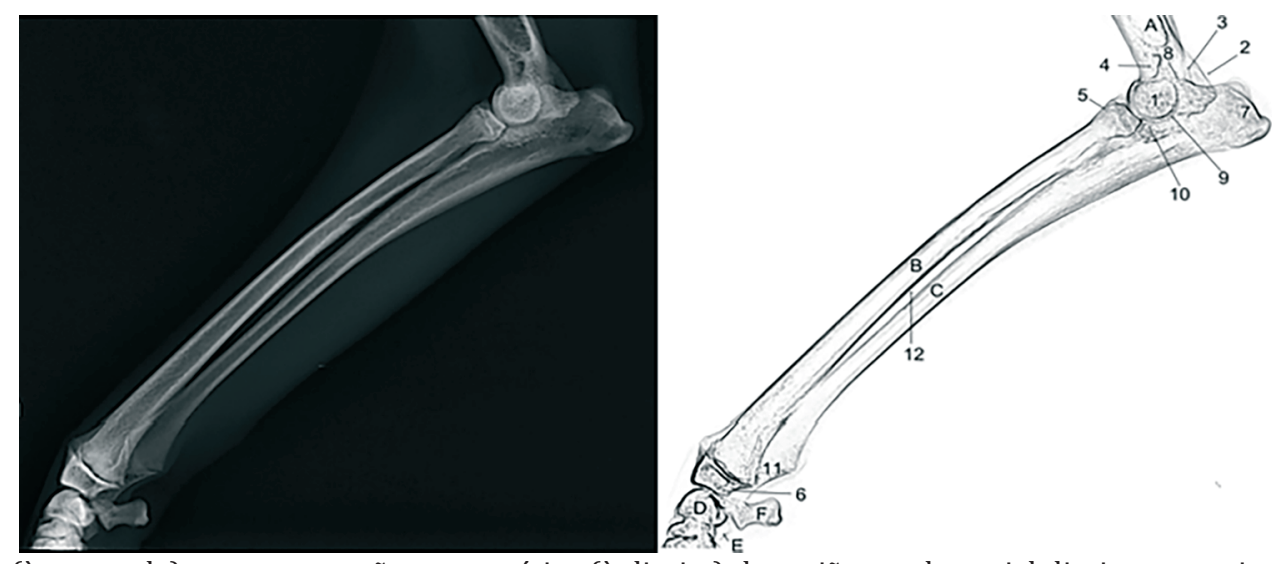

Fig.19. Radiografia (à esquerda) e representação esquemática (à direita) da região antebraquial direita em projeção médio-lateral, de espécime macho de Lycalopex gymnocercus revelando os ossos úmero (A), rádio (B), ulna (C), osso carpiano intermédio-radial (D), osso carpiano ulnar (E) e osso carpiano acessório (F) e os acidentes anatômicos côndilo umeral (1), epicôndilo medial (2), epicôndilo lateral (3), forame supratroclear (4), cabeça do rádio (5), processo estiloide medial (6), tuberosidade do olecrano (7), processo ancôneo (8), incisura troclear (9), processo coronoide medial (10), disco epifisário cartilagíneo (11), espaço interósseo (12).
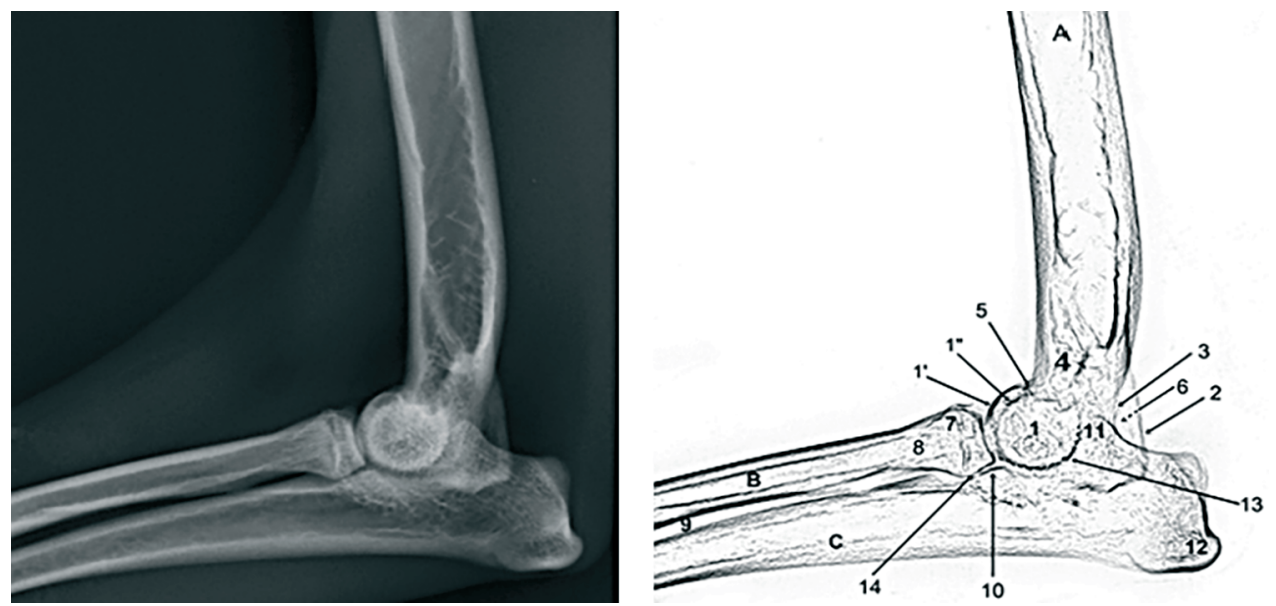

Fig.20. Radiografia (à esquerda) e representação esquemática (à direita) da região úmero-rádio-ulnar direita, em semiflexão, de espécime macho de Lycalopex gymnocercus na projeção mediolateral revelando os ossos úmero (A), rádio (B), ulna (C) e os acidentes anatômicos côndilo umeral (1), trócela umeral (1'), Capítulo (1'), epicôndilo medial (2), epicôndilo lateral (3), forame supratroclear (4), fossa radial (5), fossa do olecrano (6), cabeça do rádio (7), colo do rádio (8), espaço interósseo (9), processo coronoide medial (10), processo ancôneo (11), tuberosidade do olecrano (12), incisura troclear (13). 

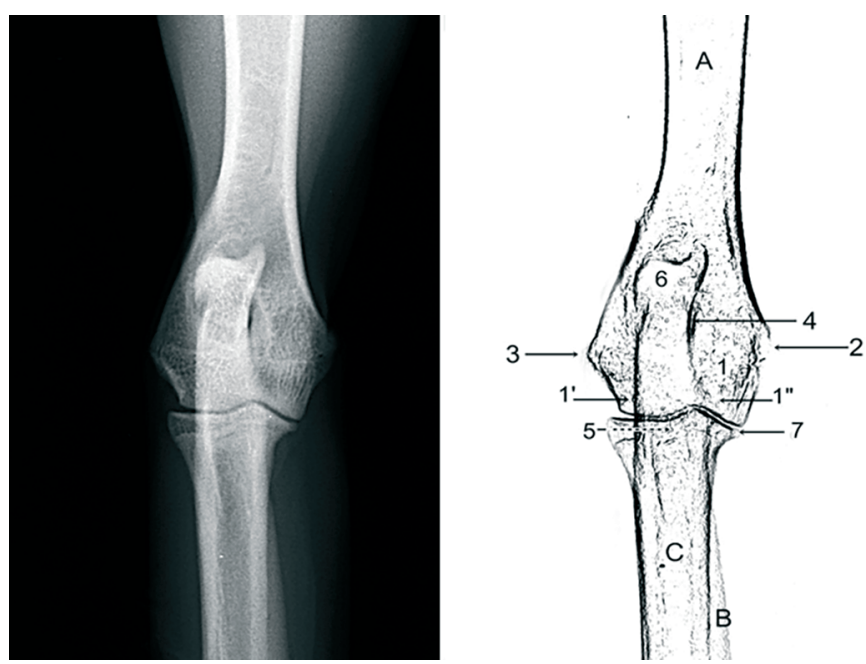

Fig.21. Radiografia (à esquerda) e representação esquemática (à direita) da região úmero-rádio-ulnar direita em projeção crânio-caudal, de espécime macho de Lycalopex gymnocercus revelando os ossos úmero (A), rádio (B) e ulna (C) e os acidentes anatômicos côndilo umeral (1), capítulo (1), tróclea (1"), epicôndilo medial (2), epicôndilo lateral (3), forame supratroclear (4), cabeça do rádio (5), tuberosidade do olecrano (6), processo coronoide medial (7).
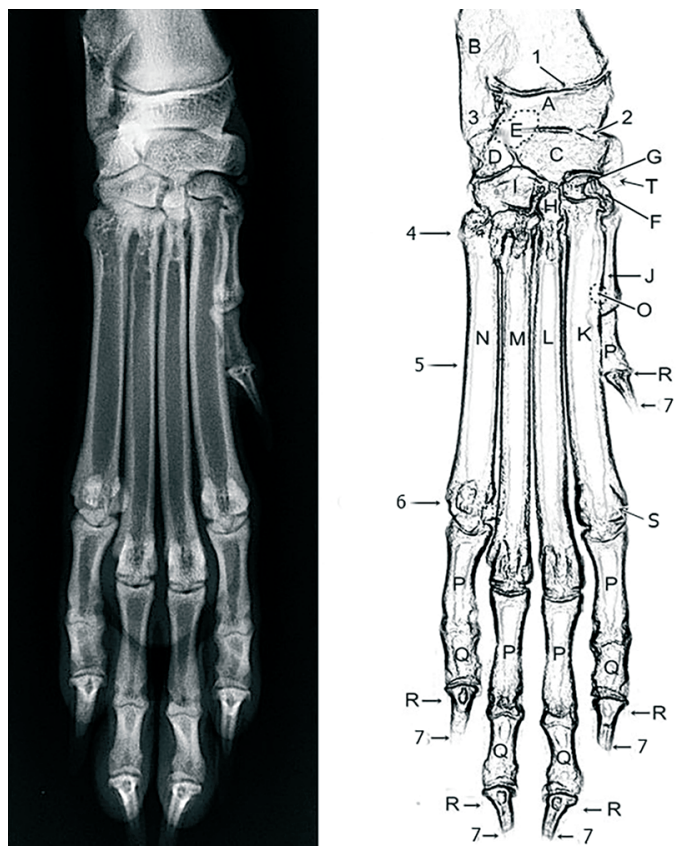

Fig.22. Radiografia (à esquerda) e representação esquemática (à direita) da região da mão direita, em projeção dorso-palmar, de espécime macho de Lycalopex gymnocercus revelando os ossos epífise distal do rádio (A), ulna (B), osso carpiano intermédio-radial (C), osso carpiano ulnar (D), osso carpiano acessório (E), osso carpiano primeiro (F), osso carpiano segundo (G), osso carpiano terceiro (H), osso carpiano quarto (I), osso metacarpiano primeiro (J), osso metacarpiano segundo (K), osso carpiano terceiro (L), osso metacarpiano quarto (M), osso metacarpiano quinto $(\mathbf{N})$, osso sesamoide proximal do dedo I (0), falange proximais (P), falanges médias (Q), falanges distais (R), osso sesamoide proximal (S), osso sesamoide do $\mathrm{m}$. abdutor longo do dedo I (T) e os acidentes anatômicos disco epifisário cartilagíneo (1), processo estiloide medial (2), processo estiloide lateral (3), base do osso metacarpiano quinto (4), corpo do osso metacarpiano quinto (5), cabeça do osso metacarpiano quinto (6) e processos ungueais das falanges distais (7).
C. l. familiaris. 0 disco epifisário cartilagíneo distal apresentou-se em forma de cunha (Fig.22).

A osteometria tridimensional permitiu inferir que a região articular proximal do rádio e da ulna era formada pela cabeça do rádio $\left(60,03 \mathrm{~mm}^{2}\right)$, processo coronoide medial da ulna $\left(12,67 \mathrm{~mm}^{2}\right)$, processo coronoide lateral $\left(8,18 \mathrm{~mm}^{2}\right)$ e incisura troclear $\left(101,17 \mathrm{~mm}^{2}\right)$. Pode-se, assim, quantificar que para a formação da superfície articular para o úmero, o rádio contribuiu em 33\% e a ulna em $67 \%$.

Durante a fase de apoio do membro torácico no solo, o úmero exerce carga praticamente sobre os processos coronoides da ulna e cabeça do rádio, as quais são superfícies mais distais em comparação com a incisura troclear. Assim, desconsiderando-se a incisura troclear, pode-se estimar que durante a fase de apoio a cabeça do rádio forneça superfície para suportar cerca $74 \%$ da carga umeral, enquanto o processo coronoide medial suportaria $16 \%$ e o lateral apenas $10 \%$. A razão entre as áreas dos côndilos umerais e superfície articular rádio-ulnar foi de 1,5 o que confirma a grande amplitude do movimento do cotovelo no plano sagital.

A tróclea radial apresentou área $82,46 \mathrm{~mm}^{2}$ enquanto a superfície articular distal da ulna para os ossos carpianos $14,51 \mathrm{~mm}^{2}$. A partir destas mensurações, pode-se confirmar que a ulna predominou em relação ao rádio quanto à formação da articulação do cotovelo (67\% e 33\%, respectivamente). Inversamente, o rádio foi a principal superfície articular para os ossos carpianos proximais (85\%) em comparação com a ulna(15\%). 0 conjunto da superfície articular proximal do antebraço para o úmero correspondeu a 3,0\% da áreas totais do rádio e ulna somados $\left(5.986,12 \mathrm{~mm}^{2}\right)$; a superfície articular para a fileira proximal de ossos carpianos ocupou 1,6\% da área.

Os principais acidentes anatômicos do rádio e da ulna em um sistema de coordenadas encontram-se representados no Quadro 11. Se observado o eixo próximo-distal ("Z"), pode-se confirmar e aferir o quanto a elevação medial é pouco mais proximal que a lateral.

\section{Mão (Autopódio)}

O esqueleto da mão foi constituído pelos ossos do carpo (basipódio), metacarpo (metapódio), falanges (acropódio) proximal, média e distal dos dedos II a $\mathrm{V}$ e falanges proximal e distal do dedo I. Também foram encontrados ossos sesamoideos (ossa sesamoidea) palmares, proximais, dis-

Quadro 11. Localização dos principais acidentes anatômicos dos ossos do antebraço (rádio e ulna) de um espécime fêmea de Lycalopex gymnocercus em sistema de eixo de coordenadas

\begin{tabular}{lccc}
\hline Acidente anatômico & $\begin{array}{c}\text { Eixo X } \\
(\mathrm{mm})\end{array}$ & $\begin{array}{c}\text { Eixo Y } \\
(\mathrm{mm})\end{array}$ & $\begin{array}{c}\text { Eixo Z } \\
(\mathrm{mm})\end{array}$ \\
\hline Cabeça do rádio (incisura) & $-0,30$ & $-16,21$ & 110,35 \\
Processo estiloide medial (extremidade distal) & $-7,24$ & 0,68 & $-5,93$ \\
Incisura troclear (ponto mais côncavo) & 1,90 & $-7,97$ & 115,02 \\
Processo ancôneo (extremidade cranial) & 0,74 & $-12,27$ & 121,64 \\
Tuberosidade medial do olecrano & 1,48 & 0,51 & 132,30 \\
Tuberosidade lateral do olecrano & 6,43 & $-2,69$ & 130,89 \\
Olécrano (extremidade proximal arredondada) & 9,20 & 4,70 & 130,14 \\
Processo coronoide medial (extremidade cranial) & $-4,04$ & $-8,53$ & 110,23 \\
Processo coronoide lateral (extremidade cranial) & 6,56 & $-11,28$ & 110,64 \\
Processo estiloide lateral (extremidade distal) & 8,87 & 2,83 & $-3,86$
\end{tabular}


tais e do m. abdutor longo do dedo I (os sesamoideum $m$. abductor digiti I [pollicis] longus).

Os ossos do carpo (ossa carpi) eram curtos que contribuíram com apenas 3\% do comprimento do esqueleto do membro. Estiveram dispostos em duas fileiras: uma proximal (ou antebraquial) e outra distal (ou metacarpiana), totalizando sete ossos carpianos e um osso sesamoide do m. abdutor longo do dedo I. Esta disposição é descrita nos carnívoros domésticos (Sisson 1986) e S. suricatta (van Staden 2014). Feeney (1999) citou estes mesmos ossos para os carnívoros Urocyon, Vulpes, Martes, Canis e Procyon, a exceção do sesamoide. Na fileira proximal estão os ossos carpianos intermédio-radial (os carpi intermedioradiale), ulnar (os carpi ulnare) e acessório (os carpi accessorium), além do osso sesamoide do m. abdutor longo do dedo I. Na fileira distal encontram-se os ossos carpianos primeiro (os carpale primum), segundo (os carpale secundum), terceiro (os carpale tertium) e quarto (os carpale quartum), dispostos de medial para lateral respectivamente. 0 conjunto dos ossos do carpo apresentou um contorno convexo dorsalmente e côncavo palmarmente (Fig.23).

Feeney (1999) comparou que o carpo de canídeos tem conformação estreitada no sentido mediolateral, decorrente da redução do primeiro dedo, da redução do osso carpia-

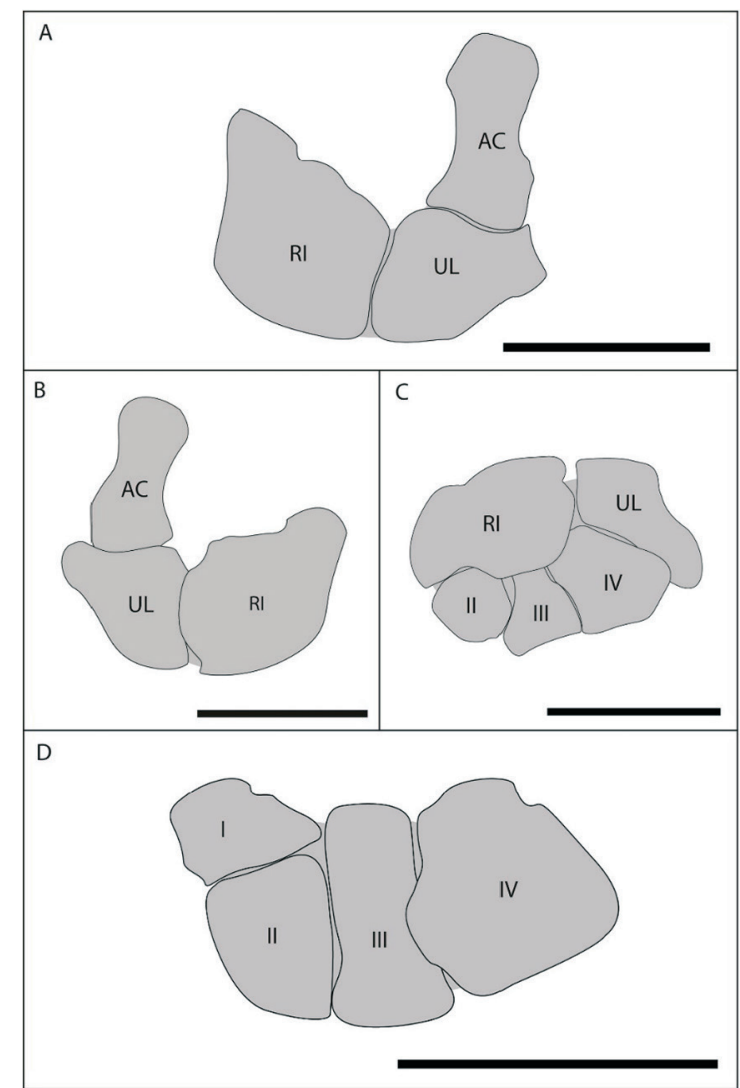

Fig.23. Representação esquemática dos ossos carpianos do membro torácico esquerdo de espécime adulto macho de Lycalopex gymnocercus. Vista da superfície articular proximal da fileira proximal (A), superfície articular distal da fileira proximal (B), dorsal do carpo completo (C) e da superfície articular proximal da fileira distal (D). Ossos carpianos intermédio-radial (RI), ulnar (UL), acessório (AC), primeiro (I), segundo (II), terceiro (III) e quarto (IV). Barra $=10 \mathrm{~mm}$.
Quadro 12. Média aritmética $(\bar{x})$, desvio padrão $(\sigma)$ das medidas obtidas nos ossos carpianos espécimes de Lycalopex gymnocercus adultos. As siglas correspondem aos ossos carpianos intermédio-radial $(C R I)$, ulnar $(C R U)$, acessório $(C A C)$, primeiro $(C I)$, segundo $(C I I)$, terceiro $(C I I)$, quarto (CIV) seguidos da medida maior largura látero-medial (GB), maior profundidade dorso-palmar $(G P)$ e maior altura próximo-distal $(G H), \mathrm{p}<0,05\left(^{*}\right)$

\begin{tabular}{|c|c|c|c|c|c|c|c|}
\hline \multirow[t]{2}{*}{ Medidas } & \multicolumn{2}{|c|}{ Geral $(n=16)$} & \multicolumn{2}{|c|}{ Fêmeas $(n=7)$} & \multicolumn{2}{|c|}{ Machos (n=9) } & \multirow{2}{*}{$\begin{array}{l}\text { Teste-t } \\
\text { p-valor }\end{array}$} \\
\hline & $\overline{\mathrm{x}}(\mathrm{mm})$ & $\sigma(\mathrm{mm})$ & $\overline{\mathrm{x}}(\mathrm{mm})$ & $\sigma(\mathrm{mm})$ & $\overline{\mathrm{x}}(\mathrm{mm})$ & $\sigma(\mathrm{mm})$ & \\
\hline CRIGB & 13,78 & 0,93 & 13,61 & 0,46 & 13,92 & 1,19 & 0,53 \\
\hline CRIGP & 8,54 & 0,64 & 8,30 & ,34 & 8,73 & 0,77 & 0,20 \\
\hline CRIGH & 6,95 & 0,89 & 6,62 & 80 & 7,20 & 0,92 & 0,21 \\
\hline CUGB & 6,86 & 0,76 & 6,37 & 61 & 7,24 & 0,65 & $0,02 *$ \\
\hline CUGP & 9,85 & 1,82 & 9,46 & 52 & 10,16 & 2,05 & 0,47 \\
\hline CUGH & 5,11 & 0,63 & 4,76 & 0,50 & 5,38 & 0,60 & $0,04^{*}$ \\
\hline CACGB & 6,53 & 0,81 & 6,14 & 0,44 & 6,83 & 0,93 & 0,10 \\
\hline CACGP & 11,02 & 0,71 & 10,89 & 0,70 & 11,11 & 0,75 & 0,56 \\
\hline CACGH & 4,89 & 1,19 & 4,53 & 1,07 & 5,17 & 1,27 & 0,30 \\
\hline CIGB & 3,45 & 0,73 & 3,48 & 0,61 & 3,43 & 0,85 & 0,90 \\
\hline CIGP & 5,21 & 0,84 & 5,33 & 0,39 & 5,11 & 1,09 & 0,61 \\
\hline CIGH & 4,34 & 1,07 & 4,09 & 1,16 & 4,54 & 1,01 & 0,41 \\
\hline CIIGB & 4,86 & 0,84 & 4,88 & 0,94 & 4,83 & 0,81 & 0,91 \\
\hline CIIGP & 5,88 & 0,68 & 5,63 & 0,74 & 6,07 & 0,59 & 0,20 \\
\hline CIIGH & 3,37 & 0,32 & 3,27 & 0,34 & 3,44 & 0,30 & 0,30 \\
\hline CIIIGB & 5,19 & 0,47 & 5,17 & 0,39 & 5,21 & 0,54 & 0,88 \\
\hline CIIIGP & 9,13 & 1,13 & 8,90 & 0,93 & 9,31 & 1,28 & 0,49 \\
\hline CIIIGH & 5,31 & 1,56 & 4,89 & 1,70 & 5,65 & 1,45 & 0,35 \\
\hline CIVGB & 7,24 & 0,49 & 7,29 & 0,70 & 7,20 & 0,28 & 0,74 \\
\hline CIVGP & 7,44 & 1,12 & 7,14 & 1,18 & 7,67 & 1,09 & 0,37 \\
\hline $\mathrm{CIVGH}$ & 6,23 & 0,60 & 6,16 & 0,42 & 6,29 & 0,73 & 0,67 \\
\hline
\end{tabular}

no primeiro e de seu posicionamento palmar em relação ao segundo e da maior proximidade do rádio com a ulna. Estas características, também encontradas em L. gymnocercus e C. thous, diferenciam a conformação geral do carpo entre canídeos e demais famílias que utilizam as mãos para outros movimentos que não apenas a caminhada ou corrida.

0 osso intermédio-radial (os scapholunatum) foi o maior dos ossos carpianos com largura média de 13,78 mm (Quadro 12). Ocupou a posição mais medial na fileira proximal e se articulou proximalmente com a tróclea do rádio, lateralmente com o osso carpiano ulnar e distalmente com os ossos carpianos primeiro, segundo e terceiro. Foi formado pela fusão entre os ossos carpiano radial e intermédio (scaphoid e lunar), o que é uma característica de todos os carnívoros modernos e parece ser uma adaptação para aumentar a estabilidade do carpo e absorver o impacto na locomoção (Ewer 1973).

O osso carpiano ulnar (os triquetrum) ocupou uma posição intermediária entre os ossos intermédio-radial e acessório na fileira proximal. Sua profundidade era maior que a largura $(9,85 \mathrm{~mm}$ e $6,86 \mathrm{~mm}$, respectivamente) e seu maior eixo tinha inclinação palmáro-distal, conforme reconhecido em C. l. familiaris (Evans \& DeLahunta 2013). Articulava-se na direção proximal com o processo estiloide da ulna, na palmar com o osso carpiano acessório, na medial com o osso intermédio radial e na distal com o osso carpiano quarto.

O osso carpiano acessório (os pisiforme) foi o mais palmar e único a permitir a fixação de músculos: da inserção do $\mathrm{m}$. flexor ulnar do carpo e da origem do $\mathrm{m}$. abdutor do dedo V, conforme descrito para C. l. familiaris (Evans \& DeLahunta 2013) e Ailuropoda melanoleuca (Endo et al. 
1996). Esta extremidade palmar assemelhou-se a um tubérculo arredondado, mais perfeitamente redondo em $C$. thous que em L. gymnocercus, descrito como típico de canídeos e também de felídeos altamente cursoriais como os existentes Panthera leo e Acinonyx jubatus e extintos como Panthera atrox e Homotherium latidens (Salesa et al. 2010). A extremidade elipsoide, achatada próximo-distalmente, seria típica de espécies cursoriais menos especializadas (Salesa et al. 2010). Corroborando essa observação, este último formato foi ilustrado por (Van Staden 2014) para $S$. suricatta, carnívoro escavador. Estabeleceu conexão dorsal com o osso carpiano ulnar e osso carpiano quarto e proximal com o processo estiloide da ulna.

Os ossos carpianos primeiro (os trapezium), segundo (os trapezoideum) e terceiro (os capitatum) estão na fileira distal e se articularam proximalmente com o osso carpiano intermédio-radial e distalmente com os ossos metacarpianos primeiro, segundo e terceiro, respectivamente. 0 osso carpiano primeiro era o menor entre os ossos do carpo e o mais medial da fileira distal, sendo posicionado mais palmarmente que dorsalmente. Estas características foram idênticas às relatadas para $S$. suricatta (Van Staden 2014). 0 osso carpiano segundo articulou-se medialmente com o osso carpiano primeiro e lateralmente com o osso carpiano terceiro. 0 osso carpiano terceiro articulou-se medialmente com o osso carpiano segundo e lateralmente com o osso carpiano quarto e dispôs de uma pequena faceta voltada distal e palmarmente para a extremidade proximal do osso metacarpiano segundo. Segundo Salesa et al. (2010) esta seria uma característica típica de canídeos e felídeos cursoriais especializados e ausente em carnívoros escaladores.

O osso carpiano quarto (os hamatum) foi o maior e mais lateral da fileira distal. Articulou-se proximalmente com o osso carpiano ulnar, medialmente com o osso carpiano terceiro, palmarmente com parte do osso carpiano acessório e distalmente com os ossos quarto e quinto metacarpianos.

$\mathrm{O}$ osso sesamoide do $\mathrm{m}$. abdutor longo do dedo I teve formato circular e apresentou uma faceta voltada medialmente para o osso carpiano intermédio-radial. A face oposta aderiu-se ao tendão de inserção do $\mathrm{m}$. abdutor longo do dedo I. Também denominado osso sesamoide radial, osso radial externo ou ainda prepolex (Ewer 1973, Le Minor 1994, Endo et al. 1996, Abella et al. 2015), está descrito em vários carnívoros e em outros mamíferos como marsupiais, roedores, primatas e quirópteros. Segundo Abella et al. (2015) este osso sesamoide é relativamente pequeno e arredondado não só nos canídeos, mas também nos felídeos, hienídeos e refletiria uma locomoção estritamente cursorial. Em contrapartida, quando este osso surge mais robusto e alongado seria compatível com espécies que necessitam de mais movimentos manuais para segurar o alimento, como alguns ursídeos, ailurídeos, mustelídeos e viverrídeos (Abella et al. 2015). Análises sobre este osso permanecem intrigantes: baseada em espécies ancestrais, Shively (1978) especulou, inclusive, que este osso poderia ser considerado como o primeiro metacarpiano. Diferentemente do osso sesamoide do m. supinador, em L. gymnocercus tinha radiopacidade suficiente para aparecer nas imagens radiográficas em projeção dorsal da região carpiana (Fig.22) e não deve
Quadro 13. Localização dos ossos carpianos de um espécime fêmea, adulto, de Lycalopex gymnocercus em sistema de eixo de coordenadas

\begin{tabular}{lccc}
\hline Osso carpiano & Eixo X(mm) & Eixo $\mathrm{Y}(\mathrm{mm})$ & Eixo Z(mm) \\
\hline Intermédio-radial & 2,86 & 3,70 & $-7,89$ \\
Ulnar & $-5,15$ & 0,88 & $-7,60$ \\
Acessório (extremidade palmar) & 13,15 & $-13,63$ & $-12,09$ \\
Primeiro & $-7,55$ & $-4,54$ & $-12,01$ \\
Segundo & $-5,44$ & $-0,71$ & $-14,27$ \\
Terceiro & $-2,24$ & 1,56 & $-13,30$ \\
Quarto & 4,77 & 2,46 & $-12,25$
\end{tabular}

ser erroneamente interpretado como um fragmento calcificado ou entesófito durante a investigação clínica.

O sistema de eixos de coordenadas quantificou a distância relativa entre os componentes carpianos, deixando claro que o carpiano primeiro é o mais palmar e o carpiano quarto é o mais dorsal na fileira distal (Quadro 13).

Os ossos metacarpianos foram cinco, sendo o primeiro o mais medial e menor de todos e o quinto o mais lateral, assim como descrito para carnívoros em geral (Ewer 1973). Articularam-se proximalmente com os ossos da fileira distal do carpo e distalmente com as falanges proximais dos respectivos dedos. 0 contorno dorsal do conjunto de metacarpianos era convexo, enquanto o contorno palmar côncavo. 0 eixo de simetria passou entre os ossos metacarpianos terceiro e quarto, caracterizando uma simetria paraxonal, conforme aludido por Feeney (1999) para cursoriais digitígrados como os canídeos e diferente do encontrado em Martes e Procyon que são menos digitígrados.

Os ossos metacarpianos seguiram uma estrutura básica onde a região proximal correspondeu à base, a diáfise

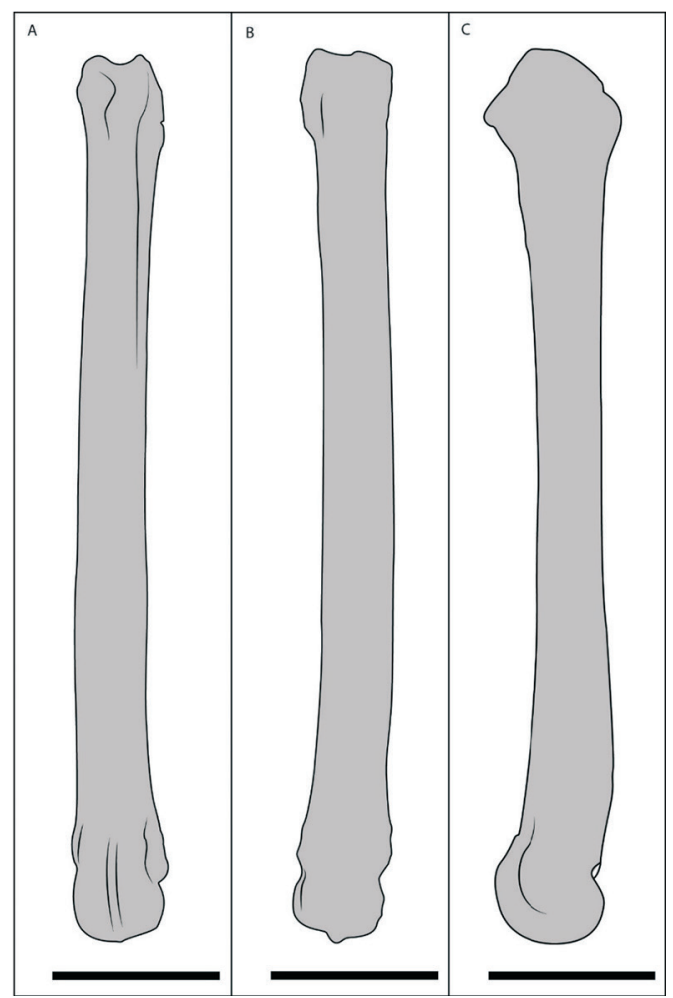

Fig.24. Representação esquemática do metacarpiano terceiro esquerdo de espécime fêmea, adulto, de Lycalopex gymnocercus em vistas palmar (A), dorsal (B) e abaxial (C) evidenciando a base proximal, o corpo alongado e a cabeça com a crista sagital direcionada palmarmente. Barra $=10 \mathrm{~mm}$. 
formou o corpo e a extremidade distal constituiu a cabeça (Fig.24). Os corpos dos ossos metacarpianos ficam aderidos, enquanto as bases e principalmente as cabeças tendem a se distanciar abaxialmente revelando os espaços intermetacarpianos. Estes espaços foram estreitos em L. gymnocercus e C. thous, o que é típico de canídeos, enquanto são relatados como amplos no gênero Procyon e ainda mais afastados no gênero Martes (Feeney 1999). O espaço mais curto pode indicar músculos interósseos menos desenvolvidos e, portanto, menos força na flexão da articulação metacarpofalangiana. Os ossos metacarpianos terceiro e quarto foram os mais compridos $(51,85 \pm 1,81 \mathrm{~mm}$ e $51,25 \pm 1,95 \mathrm{~mm}$, respectivamente), enquanto os segundo e quinto foram menos alongados $(45,86 \pm 1,72 \mathrm{~mm}$ e $43,71 \pm 2,33 \mathrm{~mm}$, respectivamente) (Quadro 14), conforme C. l. familiaris (Evans \& DeLahunta 2013). Todos os metacarpianos tiveram média de comprimento maior nos machos, sendo esta diferença significativa no segundo e quinto metacarpianos, sugerindo um aumento do comprimento dos respectivos dedos e musculatura mais robusta de modo a ampliar a superfície da mão na captura de presas e na performance locomotora conforme observado por Rocha-Barbosa et al. (2007) em roedores caviomorfos.

A base (basis) dos metacarpianos continha uma face articular (facies articularis) para a fileira distal de ossos carpianos; o corpo possuía uma face dorsal (facies dorsalis) e outra palmar (facies palmaris), uma margem medial (margo medialis) e outra lateral (margo lateralis). A face dorsal da região proximal dos corpos do segundo e terceiro metacarpianos possuía uma tuberosidade metacarpiana (tuberositas ossis metcarpalis) cada.

Ossos sesamoides se relacionavam com os metacarpianos. Os sesamoides dorsais alojavam-se em uma fossa (fossa sesamoidales) na face dorsal da cabeça de cada metacarpiano principal. Na face palmar formaram-se impressões para os pares de ossos sesamoides proximais (impressiones sesamoidales). A região palmar da superfície articular das cabeças dos metacarpianos principais apresentava uma crista sagital (cristae sagittales) cuja função seria prevenir a luxação lateral dos sesamoides (Evans \& DeLahunta 2013) e falanges (Feeney 1999), mas que também favoreceria movimentos da articulação metacarpo-falangiana no plano sagital ao se encaixar em uma fossa profunda entre os tubérculos da

Quadro 14. Média aritmética $(\bar{x})$ e desvio padrão $(\sigma)$ das medidas obtidas nos ossos metacarpianos dos espécimes de Lycalopex gymnocercus adultos. As siglas correspondem aos ossos metacarpianos primeiro (MCI), segundo (MCII), terceiro (MCIII) e quarto (MCIV), seguidos do maior comprimento (GL) ou da largura na região distal $(B d), \mathrm{p}<0,05\left(^{*}\right)$

\begin{tabular}{|c|c|c|c|c|c|c|c|}
\hline \multirow[t]{2}{*}{ Medidas } & \multicolumn{2}{|c|}{ Geral $(n=16)$} & \multicolumn{2}{|c|}{ Fêmeas $(n=7)$} & \multicolumn{2}{|c|}{ Machos $(n=9)$} & \multirow{2}{*}{$\begin{array}{l}\text { Teste-t } \\
\text { p-valor }\end{array}$} \\
\hline & $\overline{\bar{x}}(\mathrm{~mm})$ & $\sigma(\mathrm{mm})$ & $\overline{\bar{x}}(\mathrm{~mm})$ & $\sigma(\mathrm{mm})$ & $\overline{\mathrm{x}}(\mathrm{mm})$ & $\sigma(\mathrm{mm})$ & \\
\hline MCIGL & 14,86 & 1,12 & 14,38 & 0,96 & 15,23 & 1,14 & 0,13 \\
\hline MCIBd & 3,84 & 0,35 & 3,86 & 0,34 & 3,82 & 0,37 & 0,81 \\
\hline MCIIGL & 45,86 & 1,72 & 44,64 & 1,84 & 46,81 & 0,85 & $0,01 *$ \\
\hline MCIIBd & 5,76 & 0,35 & 5,77 & 0,28 & 5,76 & 0,41 & 0,97 \\
\hline MCIIIGL & 51,85 & 1,81 & 50,93 & 2,08 & 52,57 & 1,24 & 0,07 \\
\hline MCIIIBd & 4,99 & 0,42 & 4,95 & 0,44 & 5,02 & 0,43 & 0,78 \\
\hline MCIVGL & 51,25 & 1,95 & 50,20 & 2,25 & 52,07 & 1,27 & 0,05 \\
\hline MCIVBd & 5,10 & 0,37 & 5,08 & 0,36 & 5,11 & 0,39 & 0,90 \\
\hline MCVGL & 43,71 & 2,33 & 42,19 & 2,62 & 44,89 & 1,21 & $0,02^{*}$ \\
\hline MCVBd & 5,96 & 0,48 & 5,73 & 0,39 & 6,14 & 0,47 & 0,08 \\
\hline
\end{tabular}

falange proximal. Esta conformação é uma característica de mamíferos cursoriais especializados (Kardong 2011). Forames nutrícios foram visualizados na face palmar da região proximal dos ossos metacarpianos principais, conforme citado por Evans \& DeLahunta (2013) para C. l. familiaris.

0 primeiro metacarpiano era mais estreito e tinha cerca de $30 \%$ do comprimento dos demais e, destarte, foi preponderante para o encurtamento do primeiro dedo, de forma que a unha não encoste o solo e mantenha-se afiada (Ewer 1973). Articulou-se proximalmente com o osso carpiano primeiro, lateralmente com osso metacarpiano segundo e distalmente com a falange proximal do primeiro dedo. Estas características são semelhantes às descritas para carnívoros domésticos (Sisson 1986) e canídeos silvestres (Feeney 1999). Em felinos o primeiro metacarpiano também é encurtado, porém tem espessura semelhante à dos demais (Nickel et al. 1986). Em L. gymnocercus a espessura na região distal foi apenas 30\% menor que dos demais metacarpianos principais.

Ainda que Eldredge (2007) tenha classificado o primeiro dedo da mão como vestigial em C. l. familiaris, Senter \& Moch (2015) não o consideraram suficientemente reduzido para atender os critérios de uma estrutura vestigial e ressaltaram a sua importância funcional para a captura da presa, manipulação e escalada. Assim, seu encurtamento não seria a redução de uma estrutura em desuso, haja vista a existência de músculos bem desenvolvidos específicos para este dedo. 0 primeiro dedo remanesceu em todos os canídeos atuais, a exceção do gênero Lycaon, e tem persistido à seleção de raças de C. l. familiaris (Feeney 1999). Um primeiro dedo verdadeiramente vestigial seria encontrado nos gêneros Hyaena e Crocuta, onde o primeiro metacarpiano é reduzido a um pequeno bloco e a falange distal ausente (Senter \& Moch 2015). No S. suricatta o primeiro metacarpiano também é reduzido a alguns poucos milímetros e o primeiro dedo é completamente ausente (van Staden 2014). Em mustelídeos e procionídeos o primeiro dedo tende a ser funcionalmente mais atuante e, por isso, o osso metacarpiano primeiro é bem desenvolvido (Feeney 1999).

Foram identificados cinco dedos, sendo o primeiro, mais medial, formado por apenas duas falanges (proximal e distal). Os demais dedos constituíram-se de três falanges cada (proximal, média e distal). Esta disposição é idêntica a dos carnívoros domésticos (Nickel et al. 1986, Dyce et al. 2010) e também foi relatada em diversas famílias de carnívoros silvestres (Hildebrand 1954, Feeney 1999). Os canídeos $L$. gymnocercus e $C$. thous claramente apresentaram falanges que refletiam uma postura digitígrada.

Assim como os metacarpianos, cada falange proximal e média apresentou uma base, um corpo e uma cabeça (Fig. 25). As falanges proximais (os compedale) foram as mais longas (Quadro 15). Possuíam formato de bastão com duas extremidades alargadas. Na extremidade proximal ou base (basis phalangis proximalis) observou-se uma superfície articular proximal côncava e com dois tubérculos palmares separados por um sulco, onde se encaixava a crista sagital da cabeça do metacarpiano correspondente. Estas características anatômicas foram relatadas em carnívoros domésticos (Nickel et al. 1986) e também silvestres (Feeney 


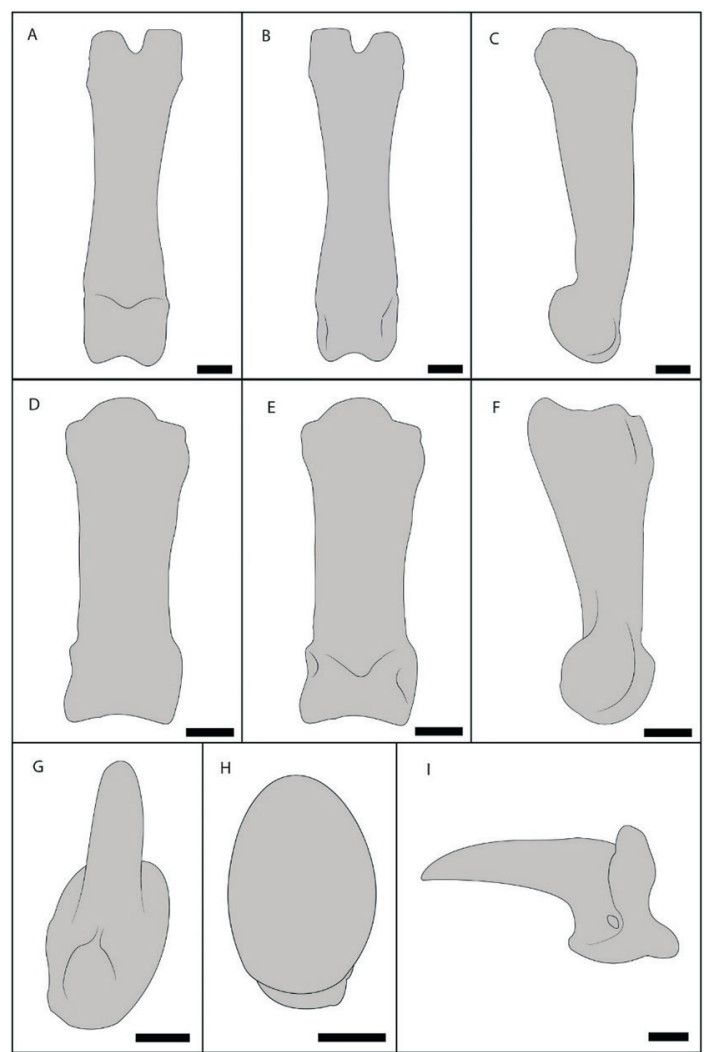

Fig.25. Representação esquemática das falanges proximal, média e distal do terceiro dedo do membro torácico esquerdo de espécime fêmea, adulto, de Lycalopex gymnocercus. Falange proximal em vistas palmar (A), dorsal (B) e abaxial (C), falange média em vistas palmar (D), dorsal (E) e abaxial (F), e falange distal em vistas palmar (G), proximal (H) e axial (I). Barra $=10 \mathrm{~mm}$.

Quadro 15. Média aritmética $(\bar{x})$ e desvio padrão $(\sigma)$ das medidas obtidas nas falanges proximais dos espécimes de Lycalopex gymnocercus adultos. As siglas correspondem às falanges proximais do primeiro dedo (FP1), segundo dedo (FP2), terceiro dedo (FP3), quarto dedo (FP4) e quinto dedo (FP5) seguidas do comprimento total (GL), largura distal $(B d)$, largura proximal $(B p)$ e menor diâmetro na diáfise $(S D), \mathrm{p}<0,05\left(^{*}\right)$

\begin{tabular}{|c|c|c|c|c|c|c|c|}
\hline \multirow[t]{2}{*}{ Medidas } & \multicolumn{2}{|c|}{ Geral $(n=16)$} & \multicolumn{2}{|c|}{ Fêmeas (n=7) } & \multicolumn{2}{|c|}{ Machos (n=9) } & \multirow{2}{*}{$\begin{array}{l}\text { Teste-t } \\
\text { p-valor }\end{array}$} \\
\hline & $\overline{\mathrm{x}}(\mathrm{mm})$ & $\sigma(\mathrm{mm})$ & $\overline{\mathrm{x}}(\mathrm{mm})$ & $\sigma(\mathrm{mm})$ & $\overline{\mathrm{x}}(\mathrm{mm})$ & $\sigma(\mathrm{mm})$ & \\
\hline FPIGL & 8,62 & 0,87 & 8,58 & 0,50 & 8,67 & 1,14 & 0,85 \\
\hline FPIBd & 3,70 & 0,32 & 3,66 & 0,25 & 3,74 & 0,38 & 0,64 \\
\hline FPIBp & 4,33 & 0,59 & 4,27 & 0,28 & 4,37 & 0,77 & 0,76 \\
\hline FPISD & 2,96 & 0,35 & 2,92 & 0,38 & 2,98 & 0,34 & 0,77 \\
\hline FPIIGL & 15,43 & 1,00 & 15,05 & 0,84 & 15,73 & 1,06 & 0,19 \\
\hline FPIIBd & 4,85 & 0,43 & 4,82 & 0,42 & 4,87 & 0,46 & 0,82 \\
\hline FPIIBp & 5,83 & 0,57 & 5,68 & 0,58 & 5,94 & 0,56 & 0,37 \\
\hline FPIISD & 3,71 & 0,42 & 3,57 & 0,39 & 3,83 & 0,42 & 0,22 \\
\hline FPIIIGL & 18,02 & 1,02 & 17,47 & 0,88 & 18,45 & 0,94 & 0,05 \\
\hline FPIIIBd & 4,50 & 0,31 & 4,43 & 0,24 & 4,55 & 0,36 & 0,45 \\
\hline FPIIIBp & 5,38 & 0,34 & 5,28 & 0,27 & 5,46 & 0,38 & 0,30 \\
\hline FPIIISD & 3,32 & 0,28 & 3,11 & 0,25 & 3,47 & 0,20 & $0,01^{*}$ \\
\hline FPIVGL & 17,84 & 1,08 & 17,50 & 0,85 & 18,10 & 1,21 & 0,28 \\
\hline FPIVBd & 4,59 & 0,31 & 4,53 & 0,29 & 4,63 & 0,33 & 0,52 \\
\hline FPIVBp & 5,38 & 0,30 & 5,28 & 0,24 & 5,46 & 0,33 & 0,23 \\
\hline FPIVSD & 3,33 & 0,24 & 3,23 & 0,20 & 3,41 & 0,24 & 0,13 \\
\hline FPVGL & 15,31 & 1,00 & 15,01 & 1,10 & 15,55 & 0,92 & 0,31 \\
\hline FPVBd & 4,77 & 0,42 & 4,57 & 0,26 & 4,92 & 0,46 & 0,10 \\
\hline FPVBp & 6,08 & 0,58 & 5,79 & 0,32 & 6,30 & 0,65 & 0,08 \\
\hline FPVSD & 3,76 & 0,38 & 3,56 & 0,17 & 3,92 & 0,44 & 0,06 \\
\hline
\end{tabular}

1999) de diferentes famílias. O sulco (ou incisura) entre os tubérculos foi descrita como mais profunda nos canídeos do que em mustelídeos e procionídeos, justamente para criar uma articulação estável no plano sagital durante a flexão, enquanto naqueles não-canídeos deve permitir uma maior variedade de movimentos dos dedos, em especial adução e abdução (Feeney 1999).

Na face palmar de cada articulação metacarpo-falangiana encontrava-se um par de ossos sesamoides. Esta região recebe grande parte do impacto do peso corporal durante a passada e, por esta razão, estava protegida por um coxim único bem desenvolvido (Feeney 1999). O corpo (corpus phalangis proximalis) era cilíndrico, com contorno convexo dorsalmente e côncavo palmarmente e se estreitava distalmente. A cabeça (caput phalangis proximalis) possuía uma superfície articular que lembrava uma tróclea, mais desenvolvida palmarmente que dorsalmente. Articulou-se com a base da falange média, formando a articulação interfalangiana proximal, tal qual em C. l. familiaris (Evans \& DeLahunta 2013).

As falanges médias (os coronale) tinham formato semelhante ao das proximais, embora mais curtas (Quadro 16).

Quadro 16. Média aritmética $(\bar{x})$ e desvio padrão $(\sigma)$ das medidas obtidas nas falanges médias dos espécimes de Lycalopex gymnocercus adultos. As siglas correspondem às falanges médias do segundo dedo (FM2), terceiro dedo (FM3), quarto dedo (FM4) e quinto dedo (FM5) seguidas do comprimento total $(G L)$, largura distal $(B d)$, largura proximal $(B p)$ e menor diâmetro na diáfise $(S D), \mathrm{p}<0,05\left(^{*}\right)$

\begin{tabular}{|c|c|c|c|c|c|c|c|}
\hline \multirow[t]{2}{*}{ Medidas } & \multicolumn{2}{|c|}{ Geral (n=16) } & \multicolumn{2}{|c|}{ Fêmeas $(n=7)$} & \multicolumn{2}{|c|}{ Machos $(n=9)$} & \multirow{2}{*}{$\begin{array}{l}\text { Teste-t } \\
p \text {-valor }\end{array}$} \\
\hline & $\overline{\mathrm{x}}(\mathrm{mm})$ & $\sigma(\mathrm{mm})$ & $\overline{\mathrm{x}}(\mathrm{mm})$ & $\sigma(\mathrm{mm})$ & $\overline{\mathrm{x}}(\mathrm{mm})$ & $\sigma(\mathrm{mm})$ & \\
\hline FMIIGL & 9,95 & 0,77 & 9,87 & 0,74 & 10,03 & 0,84 & 0,71 \\
\hline FMIIBd & 4,90 & 0,39 & 4,83 & 0,34 & 4,97 & 0,43 & 0,52 \\
\hline FMIIBp & 5,34 & 0,43 & 5,23 & 0,26 & 5,42 & 0,52 & 0,39 \\
\hline FMIISD & 3,94 & 0,41 & 3,99 & 0,27 & 3,89 & 0,52 & 0,65 \\
\hline FMIIIGL & 12,75 & 0,66 & 12,62 & 0,81 & 12,86 & 0,53 & 0,51 \\
\hline FMIIIBd & 4,56 & 0,31 & 4,38 & 0,26 & 4,72 & 0,26 & $0,03^{*}$ \\
\hline FMIIIBp & 4,89 & 0,30 & 4,73 & 0,25 & 5,01 & 0,28 & 0,06 \\
\hline FMIIISD & 3,29 & 0,26 & 3,20 & 0,22 & 3,36 & 0,29 & 0,25 \\
\hline FMIVGL & 12,89 & 0,78 & 12,69 & 0,86 & 13,07 & 0,72 & 0,37 \\
\hline FMIVBd & 4,57 & 0,30 & 4,47 & 0,26 & 4,66 & 0,32 & 0,24 \\
\hline FMIVBp & 4,85 & 0,30 & 4,81 & 0,21 & 4,88 & 0,37 & 0,65 \\
\hline FMIVSD & 3,28 & 0,44 & 3,16 & 0,44 & 3,38 & 0,45 & 0,36 \\
\hline FMVGL & 9,67 & 0,83 & 9,72 & 0,93 & 9,63 & 0,80 & 0,84 \\
\hline FMVBd & 4,89 & 0,36 & 4,81 & 0,25 & 4,95 & 0,44 & 0,48 \\
\hline FMVBp & 5,38 & 0,50 & 5,26 & 0,16 & 5,48 & 0,66 & 0,42 \\
\hline FMVSD & 4,07 & 0,38 & 4,02 & 0,16 & 4,11 & 0,51 & 0,66 \\
\hline
\end{tabular}

A base (basis phalangis mediae) possuía uma fóvea articular (fovea articularis) dividida por uma pequena crista que se encaixava na superfície articular da cabeça da falange proximal. A continuação dorsal desta crista formava um processo extensor (processus extensorius). Assim como na falange proximal, também havia dois tubérculos palmares e um sulco no meio, porém mais discretos, para a inserção dos tendões do m. flexor digital superficial. Esta disposição foi semelhante à descrita para C. l. familiaris por Evans \& DeLahunta (2013).

Segundo Ewer (1973) os felídeos e alguns viverrídeos possuem garras retráteis, enquanto canídeos e hienídeos não retrairiam as garras de forma importante. Entretanto, 
Bryant et al. (1996) mencionaram que todos os carnívoros têm capacidade de retrair as garras, porém os felídeos e viverrídeos desempenhariam uma hiper-retração. Determinaram que para que haja retração da garra, a falange média deveria ter uma concavidade na face lateral (abaxial) do seu corpo, capaz de acomodar uma maior amplitude de retração da base da falange distal. Neste raciocínio, pode-se explicar a falta de retratilidade no primeiro dedo com base na ausência da falange média.

Em L. gymnocercus, as falanges médias do segundo e quinto dedos mostraram-se mais curtas e robustas, enquanto as dos terceiro e quarto dedos eram mais longas e finas. Confirmou esta observação a comparação das medidas do diâmetro das falanges médias por meio de análise de variância (ANOVA: um critério), complementada pelo teste de Tukey. Este teste revelou que havia semelhança entre os diâmetros das falanges médias dos segundo e quinto dedos e que as mesmas eram significativamente mais largas que as dos terceiro e quarto dedos $(\mathrm{p}<0,05)$. Embora mais robustas, as falanges médias dos segundo e quinto dedos apresentaram uma concavidade acentuada em suas faces axiais, enquanto a do quarto dedo apresentou concavidade suave abaxialmente e a do terceiro dedo uma concavidade quase imperceptível axialmente. Em C. thous as concavidades das falanges médias dos segundo e quinto dedos assemelharam-se às de L. gymnocercus, porém as concavidades dos terceiro e quarto dedos foram mais acentuadas e voltadas axialmente. Portanto, em face do postulado por Bryant et al. (1996), pode-se sugerir que ambos canídeos tenham capacidade de retração das garras, especialmente dos segundo e quinto dedos. Ainda nessa linha comparativa, o $C$. thous retrairia mais a garra do que L. gymnocercus. No entanto, outros aspectos como obliquidade do tubérculo palmar da falange distal e formato das garras precisariam ser analisados para subsidiar esta inferência. Esta característica das falanges médias em L. gymnocercus e $C$. thous assemelharam-se às descritas por Feeney (1999) nos canídeos dos gêneros Canis, Urocyon e Vulpes.

As falanges distais (os unguiculare) eram semelhantes em forma nos cinco dedos. Porém a falange do primeiro dedo mostrou comprimento total significativamente menor (Quadro 17) quando comparada às demais pela análise de variância (ANOVA: um critério), complementada pelo teste de Tukey. De acordo com Evans \& DeLahunta (2013) o tamanho da falange distal seria semelhante entre os cinco dedos em C. l. familiaris. Sua superfície articular proximal era côncava e se encaixava na cabeça da falange média, compondo a articulação interfalangiana distal. A extremidade dorsal da região proximal do osso formou um processo extensor (processus extensorius) para o tendão de inserção do m. extensor comum dos dedos unido ao do m. extensor lateral dos dedos (dedos III, IV e V) e extensor dos dedos I e II. Dorsolateralmente na base do osso formou-se uma crista ungueal (crista unguicularis) que encobria a base da unha. A unha se encaixava no sulco ungueal (sulcus unguicularis).

Na extremidade palmar da base da falange distal, encontrou-se um tubérculo flexor (tuberculum flexorium) arredondado para a inserção dos tendões do m. flexor pro-
Quadro 17. Média aritmética $(\bar{x})$ e desvio padrão $(\sigma)$ das medidas obtidas nas falanges distais dos espécimes de Lycalopex gymnocercus adultos. As siglas correspondem às falanges distais do primeiro dedo (FD1), segundo dedo (FD2), terceiro dedo (FD3), quarto dedo (FD4) e quinto dedo (FD5) seguidas do comprimento total $(G L)$, altura total $(H P)$, comprimento do processo extensor ao processo ungueal $(L d)$ e maior largura $(G B), \mathrm{p}<0,05\left(^{*}\right)$

\begin{tabular}{|c|c|c|c|c|c|c|c|}
\hline \multirow[t]{2}{*}{ Medidas } & \multicolumn{2}{|c|}{ Geral $(n=16)$} & \multicolumn{2}{|c|}{ Fêmeas $(n=7)$} & \multicolumn{2}{|c|}{ Machos (n=9) } & \multirow{2}{*}{$\begin{array}{l}\text { Teste-t } \\
\text { p-valor }\end{array}$} \\
\hline & $\overline{\bar{x}}(\mathrm{~mm})$ & $\sigma(\mathrm{mm})$ & $\overline{\bar{x}}(\mathrm{~mm})$ & $\overline{\sigma(\mathrm{mm})}$ & $\overline{\mathrm{x}}(\mathrm{mm})$ & $\sigma(\mathrm{mm})$ & \\
\hline FDIGL & 8,96 & 0,65 & 8,77 & 0,41 & 9,12 & 0,80 & 0,32 \\
\hline FDIHP & 6,10 & 0,55 & 6,04 & 0,46 & 6,16 & ,65 & 0,70 \\
\hline FDILd & 9,32 & 0,88 & 9,16 & 0,97 & 9,45 & 82 & 0,54 \\
\hline FDIGB & 3,85 & 0,45 & 3,80 & ,30 & 3,90 & ,58 & ,67 \\
\hline FDIIGL & 12,88 & 0,84 & 12,99 & ,79 & 12,79 &, 92 & 0,67 \\
\hline FDIIHP & 7,38 & 0,52 & 7,20 & ,38 & 7,54 &, 59 & 0,22 \\
\hline FDIILd & 12,17 & 0,95 & 12,40 & 1,02 & 11,97 & 0,90 & 0,40 \\
\hline FDIIGB & 4,66 & 0,51 & 4,60 & 0,29 & 4,71 & 0,66 & 0,68 \\
\hline FDIIIGL & 13,12 & 0,68 & 13,14 & 0,50 & 13,10 & 0,84 & 0,93 \\
\hline FDIIIHP & 6,69 & 0,38 & 6,58 & 0,33 & 6,78 & 0,41 & 0,32 \\
\hline FDIIILd & 11,51 & 0,98 & 11,59 & 1,03 & 11,44 & 1,00 & 0,79 \\
\hline FDIIIGB & 4,18 & 0,40 & 4,07 & 0,15 & 4,28 & 0,52 & 0,31 \\
\hline FDIVGL & 13,08 & 0,69 & 13,12 & 0,68 & 13,05 & 0,75 & 0,86 \\
\hline FDIVHP & 6,59 & 0,33 & 6,40 & 0,25 & 6,75 & 0,32 & $0,04^{*}$ \\
\hline FDIVLd & 11,24 & 0,66 & 11,42 & 0,64 & 11,08 & 0,68 & 0,35 \\
\hline FDIVGB & 4,16 & 0,29 & 4,10 & 0,16 & 4,21 & 0,38 & 0,50 \\
\hline FDVGL & 12,75 & 0,98 & 12,49 & 0,99 & 12,98 & 0,98 & 0,36 \\
\hline FDVHP & 7,21 & 0,56 & 7,00 & 0,39 & 7,40 & 0,63 & 0,17 \\
\hline FDVLd & 11,89 & 1,09 & 11,78 & 1,08 & 11,99 & 1,17 & 0,73 \\
\hline FDVGB & 4,66 & 0,52 & 4,51 & 0,35 & 4,80 & 0,62 & 0,30 \\
\hline
\end{tabular}

fundo dos dedos nas cinco falanges distais. Em C. thous e $C$. l. familiaris este tubérculo é mais perfeitamente arredondado enquanto em L. gymnocercus é mais alongado no sentido próximo-distal. De modo geral, este formato de tubérculo arredondado foi semelhante ao ilustrado por Hildebrand (1954) para os gêneros cursoriais especializados Canis e Chrysocyon, diferente do gênero Fennecus que é adaptado para escalar. Neste último, o tubérculo é quase plano e bastante alongado. Van Staden (2014) referiu um tubérculo flexor ovalado para $S$. suricatta cujo hábito é semifossorial. Cada tubérculo estava protegido externamente por um coxim digital (Dyce et al. 2010). Cada face deste tubérculo continha um forame solear (foramen soleare axialis e foramen soleare abaxiale) que se comunicavam formando um canal vascular solear (canalis solearis). Dois forames também se formavam próximos ao processo extensor sem, contudo, configurar um canal vascular. A parte distal da falange distal originou um processo ungueal (processus unguicularis) de formato cônico, achatado látero-lateralmente e curvado palmarmente na região apical, tal qual em C. l. familiaris (Evans \& DeLahunta 2013). Tanto o achatamento como a curvatura são mais pronunciadas em felídeos do que em canídeos (Nickel et al., 1986), decorrente de uma maior necessidade de perfuração da presa (Salesa et al. 2010).

Ao se somarem as médias dos comprimentos dos ossos formadores dos dedos (metapodais e acropodais), verificou-se que o terceiro dedo era em média o mais comprido, ainda que não diferisse significativamente do comprimento do quarto. 0 segundo dedo era mais comprido que o quinto, sem diferença significativa entre ambos. 0 primeiro dedo era bem reduzido em relação aos demais (Fig.26). 


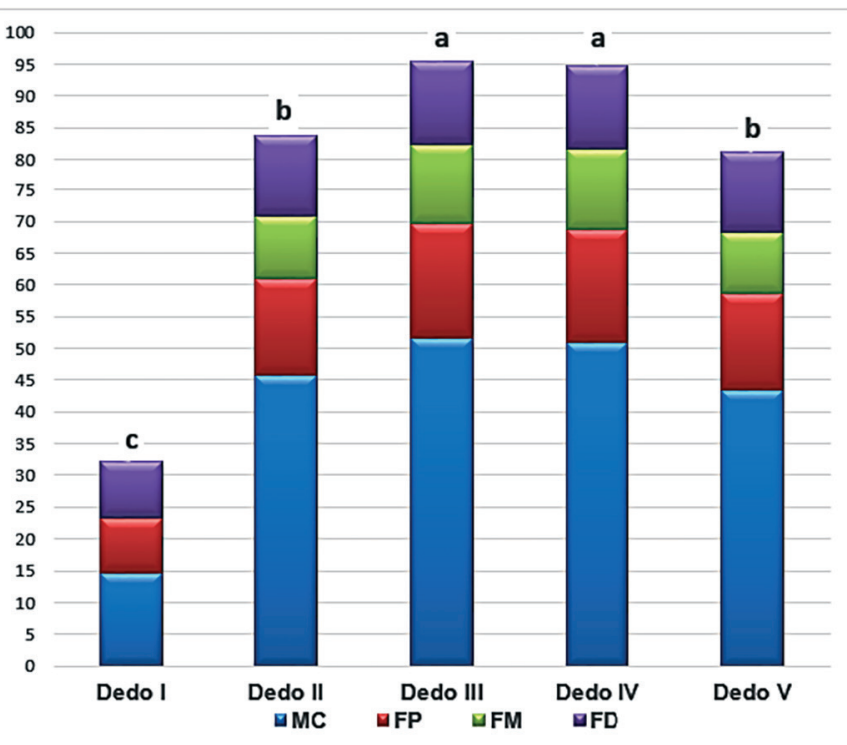

Fig.26. Gráfico representando o comprimento médio total ( $\mathrm{mm})$ dos dedos da mão de dezesseis espécimes adultos de Lycalopex gymnocercus, determinado pela soma dos comprimentos médios dos metacarpianos (azul), falanges proximais (vermelho), médias (verdes) e distais (lilás). Colunas com letras diferentes no topo indicam diferença significativa $(\mathrm{p}<0,05)$ à análise de variância complementada pelo teste de Tukey.

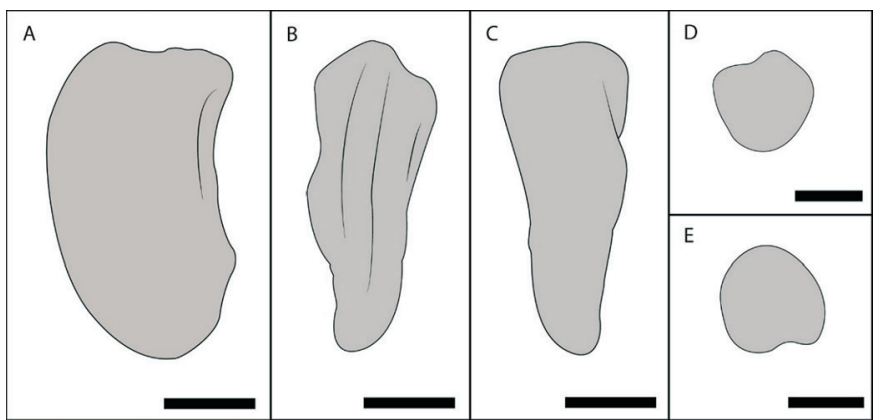

Fig.27. Ossos sesamoides proximal e dorsal do terceiro dedo do membro torácico esquerdo de espécime fêmea, adulto, de $L y$ calopex gymnocercus. Sesamoide proximal em vistas abaxial (A), palmar (B), dorsal (C) e sesamoide dorsal em vistas dorsal (D) e palmar (E). Barra $=2 \mathrm{~mm}$.

Ossos sesamoides proximais eram pares, presentes na face palmar das articulações metacarpo-falangianas dos dedos II a V, facilmente identificáveis nas radiografias em projeção dorso-palmar da mão. Na face palmar da articulação metacarpo-falangiana do primeiro dedo encontrou-se apenas um único sesamoide. Estes sesamoides proximais eram os maiores do membro torácico e tinham formato alongado no sentido próximo-distal (Fig.27). 0 comprimento dos sesamoides axiais e abaxiais foi semelhante entre os dedos (Quadro 18). Entre o par de sesamoides formava-se uma canaleta para direcionar um trajeto sagital para os tendões flexores. Nos sesamoides proximais se inseriram parte dos músculos interósseos.

Ossos sesamoides distais são referidos em C. l. familiaris como cartilagíneos (Sisson 1986, Nickel et al. 1986), mas foram visualizados de forma inconstantes nos esqueletos do presente estudo. Van Staden (2014) referiu a ocorrência
Quadro 18. Média aritmética $(\bar{x})$ e desvio padrão $(\sigma)$ das medidas obtidas nos ossos sesamoides dorsais dos espécimes de Lycalopex gymnocercus adultos. As siglas correspondem aos sesamoides proximais $(S P)$, seguidos de axial $(A x)$ ou abaxial $(A b)$, comprimento $(L)$ ou largura $(B)$ e o número do dedo (2 a 5)

\begin{tabular}{|c|c|c|c|c|c|c|c|}
\hline \multirow[t]{2}{*}{ Medidas } & \multicolumn{2}{|c|}{ Geral $(n=16)$} & \multicolumn{2}{|c|}{ Fêmeas (n=7) } & \multicolumn{2}{|c|}{ Machos $(n=9)$} & \multirow{2}{*}{$\begin{array}{l}\text { Teste-t } \\
\text { p-valor }\end{array}$} \\
\hline & $\overline{\mathrm{x}}(\mathrm{mm})$ & $\sigma(\mathrm{mm})$ & $\overline{\mathrm{x}}(\mathrm{mm})$ & $\sigma(\mathrm{mm})$ & $\overline{\mathrm{x}}(\mathrm{mm})$ & $\sigma(\mathrm{mm})$ & \\
\hline SPAxL2 & 5,89 & 0,53 & 6,14 & 0,37 & 5,64 & 0,62 & 0,30 \\
\hline SPAbL2 & 5,83 & 0,27 & 6,02 & 0,22 & 65 & ,18 & 08 \\
\hline SPAxB2 & 2,60 & 0,18 & 2,55 & 0,24 & 65 & 11 & 0,53 \\
\hline SPAbB2 & 2,57 & 0,25 & 47 & 0,26 & 67 &, 25 & 0,38 \\
\hline SPAxL3 & 6,47 & 0,54 & 6,48 & 0,45 & 6,46 &, 72 & 0,98 \\
\hline SPAbL3 & 6,36 & 0,41 & 6,35 & 0,30 & 6,38 & ,58 & 0,95 \\
\hline SPAxB3 & 2,57 & 0,25 & 2,39 & 0,19 & 2,76 & 0,15 & 0,06 \\
\hline SPAbB3 & 2,48 & 0,12 & 2,41 & 0,14 & 2,55 & 0,00 & 0,23 \\
\hline SPAxL4 & 6,53 & 0,38 & 6,56 & 0,13 & 6,50 & 0,58 & 0,87 \\
\hline SPAbL4 & 6,48 & 0,55 & 6,51 & 0,36 & 6,46 & 0,80 & 0,93 \\
\hline SPAxB4 & 2,37 & 0,23 & 2,31 & 0,27 & 2,44 & 0,21 & 0,53 \\
\hline SPAbB4 & 2,42 & 0,31 & 2,20 & 0,26 & 2,63 & 0,18 & 0,08 \\
\hline SPAxL5 & 5,77 & 0,41 & 5,75 & 0,62 & 5,80 & 0,21 & 0,90 \\
\hline SPAbL5 & 5,31 & 0,47 & 5,42 & 0,43 & 5,20 & 0,58 & 0,62 \\
\hline SPAxB5 & 2,54 & 0,11 & 2,57 & 0,14 & 2,51 & 0,07 & 0,50 \\
\hline SPAbB5 & 2,62 & 0,26 & 2,57 & 0,39 & 2,67 & 0,08 & 0,67 \\
\hline
\end{tabular}

destes sesamoides próximos aos tendões flexores dos dedos III, IV e V em S. suricatta.

Os sesamoides dorsais localizaram-se na face dorsal da articulação metacarpo-falangiana em uma fossa apropriada. Cada dedo possuía um único sesamoide pequeno e arredondado cuja função era evitar o atrito dos tendões extensores com a face dorsal da articulação. Ossos sesamoides foram relatados como cartilagíneos na face dorsal das articulações interfalangianas proximais e distais em $C$. l. familiaris (Nickel et al. 1986, Sisson 1986), mas também foram inconstantes nos espécimes deste estudo.

\section{Aspectos funcionais e evolutivos}

A análise multimodal do esqueleto do membro torácico de L. gymncercus permitiu constatar diversas adaptações funcionais e evolutivas típicas de espécies cursoriais especializadas. Algumas características anatômicas têm significado funcional claro para privilegiar a velocidade e o menor gasto energético da locomoção, enquanto outras não têm significado aparente, mas se repetem em espécies com hábitos locomotores semelhantes e/ou proximidade filogenética. Tais adaptações ocorreram em praticamente todos os segmentos do membro e podem ser sumarizadas a seguir:

A escápula fina e alongada, com margem cranial pouco arqueada e exibindo um processo supra-hamato relativamente bem desenvolvido para facilitar a protração do membro pelo $\mathrm{m}$. omotransverso.

0 úmero delgado e leve com cabeça achatada que favorece movimentos no plano sagital; tubérculo maior elevado para favorecer a extensão do ombro realizada pelo $\mathrm{m}$. supra-espinhal; sulco intertubercular voltado cranialmente para restringir o tendão do $\mathrm{m}$. bíceps braquial a movimentos no plano sagital; tróclea com sulco profundo para aumentar a estabilidade do cotovelo durante os movimentos de extensão e flexão do cotovelo; fossas radial e do olecrano profundas para aumentar a superfície articular de movimentos sagitais no cotovelo; ausência de forame supracon- 
dilar acarreta redução do epicôndilo medial e consequente redução da área para músculos antebraquiais mais delgados e de contração mais rápida.

Rádio delgado e leve; ulna com elevação medial na tuberosidade do olecrano comum a canídeos em geral e felinos velocistas.

Esqueleto do carpo estreitado no sentido látero-medial com osso carpiano primeiro reduzido e disposto palmarmente para reduzir a área de abrangência das mãos; fusão dos ossos carpianos radial e intermédio para conferir robustez para suportar o impacto da locomoção veloz e simplificar as possibilidades de mobilidade carpiana ao plano sagital; tubérculo palmar arredondado no osso carpiano acessório e faceta do carpiano terceiro para o metacarpiano segundo são característicos de canídeos e felinos velozes; sesamoide do m. abdutor longo do primeiro dedo pequeno e arredondado comum a carnívoros cursoriais.

Metacarpianos em número de cinco, com o primeiro reduzido para garantir o encurtamento do primeiro dedo, necessário para a preservação da unha do primeiro dedo afiada; espaços intermetacarpianos estreitos devido à menor demanda de atuação dos mm. Interósseos crista sagital na cabeça dos metacarpianos para melhorar a estabilidade da articulação metacarpo-falangiana e restringir os movimentos de adução ou abdução dos dedos.

Ausência de falange média no primeiro dedo para mantê-lo encurtado, porém funcional; falanges adaptadas para apoio digitígrado típico de carnívoros cursoriais; capacidade de retração das garras.

Além das características elencadas, os índices morfológicos propostos por Samuels et al. (2013) permitiram categorizar L. gymnocercus como um cursorial especializado. Ainda que não considerem a escápula, os índices propostos por Samuels et al. (2013) corroboraram com a percepção macroscópica da similitude entre o esqueleto do membro torácico de L. gymnocercus e C. thous.

Em suma, estas características inferidas a partir da inspeção visual dos ossos e confirmadas por métodos osteométricos bi e tridimensionais são consideradas adaptações para passadas maiores, velocidade aumentada e gasto energético diminuído durante o deslocamento em maiores distâncias. Isto se aplica a L. gymnocercus que tem o hábito de forragear solitariamente, ainda que ocupe uma área média de apenas 2,63km² (55-461 ha) (Lucherini \& Luengos Vidal 2008), sem diferir entre machos e fêmeas (Luengos Vidal et al. 2012). Ossos robustos seriam necessários para situações como manipular presas de maior porte ou para o nado (Martín-Serra et al. 2014), o que não é o caso de $L$. gymnocercus cuja dietas baseia-se em roedores, coleópteros, pássaros, frutas e sementes e não têm hábitos semiaquáticos (Vieira \& Port, 2007).

Em média, as medidas dos ossos e o comprimento total dos membros dos machos eram maiores que os das fêmeas. A região distal do úmero dos machos foi significativamente mais larga $(p<0,05)$, justificada pela fixação de músculos antebraquiais mais fortes. Curiosamente, outra estrutura significativamente maior em machos do que em fêmeas era vestigial: a clavícula.

Interessante antecipar que essas características de os- sos delgados e alongados encontradas no membro torácico dos canídeos tendem a se repetir no membro pélvico, visto que nos quadrúpedes cursoriais ambos os membros são afetados por necessidades biomecânicas semelhantes. Tal integração foi elucidada por Martín-Serra et al. (2015). Estes autores assinalaram também que, quanto mais distal o osso está localizado em um membro, mais o seu formato e dimensões estão sujeitos a adaptações funcionais. Ossos distais sofrem menos restrições durante a fase de crescimento pois seus discos epifisários distais fecham posteriormente.

Por fim, cabe salientar que as modalidades osteométricas tridimensionais utilizadas neste estudo permitiram inferir características que não seriam possíveis por métodos descritivos, como o cálculo de áreas e posições relativas dos acidentes em relação a um marco predeterminado. Quando examinados um maior número ou variedade de espécies com esta metodologia será possível esclarecer ainda mais as características ecomorfológicas dos carnívoros.

\section{CONCLUSÕES}

A avalição multimodal do esqueleto do membro torácico de Lycalopex gymnocercus permitiu concluir que os ossos são eficientemente adaptados para uma locomoção cursorial especializada e veloz com movimentos manuais para capturar presas menores. Houve uma tendência de a ossatura ser mais alongada e larga nos machos.

As clavículas vestigiais têm natureza cartilagínea e são significativamente mais desenvolvidas nos machos. Os acidentes anatômicos são semelhantes aos de canídeos domésticos e silvestres como possível expressão da proximidade filogenética e dos movimentos mais restritos ao plano sagital.

\section{REFERÊNCIAS}

Abella J., Pérez-Ramos A., Valenciano A., Alba D.M., Ercoli M.D., Hontecillas D., Montoya P. \& Morales J. 2015. Tracing the Origin of the Panda's Thumb. Sci. Nat. 102(35):1-13.

Andersson K. 2004. Elbow-Joint Morphology as a Guide to Forearm Function and Foraging Behaviour in Mammalian Carnivores. Zool. J. Linn. Soc. 142:91-104.

Baum H. \& Zietzschmann O. 1936. Handbuch Der Anatomie Des Hundes. Band 1, Verlag Paul Parey, Berlin.

Bryant H.N., Russell A.P., Laroiya R. \& Powell G.L. 1996. Claw Retraction and Protraction in the Carnivora: Skeletal Microvariation in the Phalanges of the Felidae. J. Morphol. 229:289-308.

Černý H. \& Čižinauskas S. 1995. The Clavicle of Newborn Dogs. Acta Vet. Brno 64:139-145.

CNEN - Comissão Nacional de Energia Nuclear. 2014. Diretrizes Básicas de Proteção Radiológica. 22p. Disponível em <http://appasp.cnen.gov.br/ seguranca/normas/pdf/Nrm301.pdf>. Acesso em 08 jun. 2013.

Donat K. 1971. Die Fixierung Der Clavicula Bei Katze Und Hund. Anat. Anz. 128:365-374.

Dyce K., Sack W. \& Wensing C. 2010. Tratado de Anatomia Veterinária. 4a ed. Elsevier, Rio de Janeiro.

Eldredge D. 2007. Dog Owner's Home Veterinarian Book. 4th ed. Howell Book House, Hoboken.

Endo H., Sasaki N., Yamagiwa D., Uetake Y., Kurohmaru M. \& Hayashi Y. 1996. Functional Anatomy of the Radial Sesamoid Bone in the Giant Panda (Ailuropoda melanoleuca). J. Anat. 189:587-592.

Evans H.E. \& DeLahunta A. 2013. Miller's Anatomy of the Dog. $4^{\text {th }}$ ed. Saunders Elsevier, St Louis. 
Ewer F.G. 1973. The Carnivores. Cornell University Press, Ithaca.

Fabre A.C., Cornette R., Goswami A. \& Peigné S. 2015. Do Constraints Associated with the Locomotor Habitat Drive the Evolution of Forelimb Shape? A Case Study in Musteloid Carnivorans. J. Anat. 226:596-610.

Fabre A.C., Goswami A., Peigné S. \& Cornette R. 2014. Morphological Integration in the Forelimb of Musteloid Carnivorans. J. Anat. 225:19-30.

Feeney S. 1999. Comparative Osteology, Myology \& Locomotor Specializations of the Fore \& Hind Limbs of the North American Foxes Vulpes vulpes \& Urocyon cinereoargenteus, University of Massachusets, Amherst.

Ferreira C.C., Souza Junior P., Santos A.L.Q., Mendes D.R. \& Fontes J.A. 2016. 3D Scanner and CAD Software Application in Animal Osteometry. Biosci. J. 32(3):705-712.

Hildebrand M. 1954. Comparative Morphology of the Body Skeleton in Recent Canidae. Univ. California Publ. Zool. 52:399-470.

ICVGAN- International Committee of Veterinary Gross Anatomy Nomenclature. 2012. Nomina Anatomica Veterinaria. 5th ed. Editorial Committee: Hannover.

Janis C.M. \& Figueirido B. 2014. Forelimb Anatomy and the Discrimination of the Predatory Behavior of Carnivorous Mammals: The Thylacine as a Case Study. J. Morphol. 275:1321-1338.

Jiménez J.E., Lucherini M. \& Novaro A.J. 2008. Pseudalopex gymnocercus. Disponível em <http://www.iucnredlist.org/details/6928/0.> Acesso em 08 jun. 2016

Kardong K. 2011. Vertebrados: Anatomia Comparada, Função e Evolução. $5^{\underline{a}}$ ed. Editora Roca, São Paulo.

Klatt B. 1928. Vergleichende Untersuchungen an Caniden Und Procyniden. Zool. Jahrbücher. Abteilung für Allg. Zool. und Physiol. der Tiere. 45:217-292.

Liem K., Bemis W., Walker Jr. W. \& Grande L. 2013. Anatomia Funcional Dos Vertebrados. $3^{\mathrm{a}}$ ed. Cengage Learning, São Paulo.

Lucherini M. \& Luengos Vidal E.M. 2008. Lycalopex gymnocercus (Carnivora: Canidae). Mamm. Species 820:1-9.

Luengos Vidal E.M., Sillero-Zubiri C., Marino J., Casanave E.B. \& Lucherini M. 2012. Spatial Organization of the Pampas Fox in a Grassland Relict of Central Argentina: A Flexible System. J. Zool. 287:133-141.

Martín-Serra A., Figueirido B. \& Palmqvist P.A. 2014. Three-Dimensional Analysis of Morphological Evolution \& Locomotor Performance of the Carnivoran Forelimb. PLoS One. 9:e85574.

Martín-Serra A., Figueirido B., Pérez-Claros J.A. \& Palmqvist P. 2015. Patterns of Morphological Integration in the Appendicular Skeleton of Mammalian Carnivores. Evolution (N. Y). 69:321-340.

McCarthy P.H. \& Wood A.K.W. Anatomic \& Radiologic Observations of the Clavicle of Adult Dogs. 1988. Am. J. Vet. Res. 49:956-959.

Meachen-Samuels J. 2010. Comparative Scaling of Humeral Cross-Sections of Felids \& Canids Using Radiographic Images. J. Mamm. Evol. 17:193209.

Meloro C. \& Louys J. 2015. Ecomorphology of Radii in Canidae: Application to Fragmentary Fossils from Plio- Pleistocene Hominin Assemblages. Acta Palaeontol. Pol. 60:795-806.

Meloro C., Elton S., Louys J., Bishop L.C. \& Ditchfield P. 2013. Cats in the Forest: Predicting Habitat Adaptations from Humerus Morphometry in Extant \& Fossil Felidae (Carnivora). Paleobiology 39:323-344.

Le Minor J.M. 1994. The Sesamoid Bone of Musculus Abductor Pollicis
Longus (Os Radiale Externum or Prepollex) in Primates. Acta Anat. (Basel). 150:227-231.

Nickel R., Schummer A., Seiferle E., Frewein J., Wilkens H. \& Wille K.H. 1986. The Locomotor System of the Domestic Mammals. 5th ed. Verlag Paul Parey, Berlin.

Pagenstretcher H.A. 1870. Die Jagdhyäne (Lycaon pictus). Der Zool. Garten 11: 197-213.

Queirolo D., Kasper C.B. \& Beisiegel B.M. 2013. Avaliação Do Risco de Extinção Do Graxaim-Do-Campo Lycalopex gymnocercus (G. Fischer, 1814) no Brasil. Biodiversidade Bras. 3: 172-178.

Rocha-Barbosa O., Youlatos D., Gasc J.P. \& Renous S. 2002. The Clavicular Region of Some Cursorial Cavioidea (Rodentia, Mammalia). Mammalia. 66:413-421.

Rocha-Barbosa O., Loguercio M.F., Renous S. \& Gasc J.P. 2007. Comparative study on the forefoot and hindfoot intrinsic muscles of some Cavioidea rodents (Mammalia, Rodentia). Zoology Jena Alemania, 110:58-65.

Ruscillo D. 2002. The Table Test: A Simple Technique for Sexing Canid Humeri. In: Ruscillo D. (Ed.) Recent Advances in Ageing \& Sexing Animal Bones. Oxbow Books, Oxford, p.62-67.

Salesa M.J., Antón M., Turner A. \& Morales J. 2010. Functional Anatomy of the Forelimb in Promegantereon* Ogygia (Felidae, Machairodontinae, Smilodontini) from the Late Miocene of Spain and the Origins of the Sabre-Toothed Felid Model. J. Anat. 216:381-396.

Samuels J.X., Meachen J.A. \& Sakai S.A. 2013. Postcranial Morphology \& the Locomotor Habits of Living and Extinct Carnivorans. J. Morphol. 274:121-146.

Schebitz H. \& Wilkens H. 1987. Atlas of Radiographic Anatomy of the Dog and Cat. 4th ed., W.B. Saunders, Philadelphia.

Senter P. \& Moch J.G.A. 2015. Critical Survey of Vestigial Structures in the Postcranial Skeletons of Extant Mammals. Peer J. 3:e1439.

Shahar R. \& Milgram J. 2005. Morphometric and Anatomic Study of the Forelimb of the Dog. J. Morphol. 263:107-117.

Shively M.J. 1978. First Metacarpal Bone or Proximal Phalanx? Vet. Radiol. 19:50-52.

Silva M.F.M., Souza W.V., Almada R.M.F., Carvalho A.D. \& Souza Junior P. 2015. Anatomía Comparada de Los Músculos Supinador Y Pronador Redondo de Tres Especies Carnívoras Silvestres. Rev. Argentina Anatomía Online. 6(3):28-33.

Sisson S. 1986. Osteologia do Carnívoro. In: Getty R. (Ed.) Anatomia dos Animais Domésticos. 5ª ed. Guanabara Koogan, Rio de Janeiro, p.13371412.

van Staden S.L. 2014. Thoracic Limb of the Suricate (Suricata suricatta): Osteology, Radiologic Anatomy, and Functional Morphologic Changes. J. Zoo Wildl. Med. 45:476-486.

Stoskopf M.K. 1989. Clinical Imaging in Zoological Medicine: A Review. J. Zoo Wildl. Med. 20:396-412.

Vieira E.M. \& Port D. 2007. Niche Overlap and Resource Partitioning between Two Sympatric Fox Species in Southern Brazil. J. Zool. 272:57-63.

Von-den-Driesch A. 1976. A Guide to the Measurement of Animal Bones from Archaeological Sites. Peabody Museum Press, Harvard.

Wang X. 1993. Transformation from Pantigrady to Digitigrady: Functional Morphology of Locomotion in Hesperocyon (Canidae: Carnivora). Am. Museum Novit. 3069:1-23. 